Prepared in cooperation with Bureau of Land Management

\title{
Mineral Resource Inventory of North Dakota
}

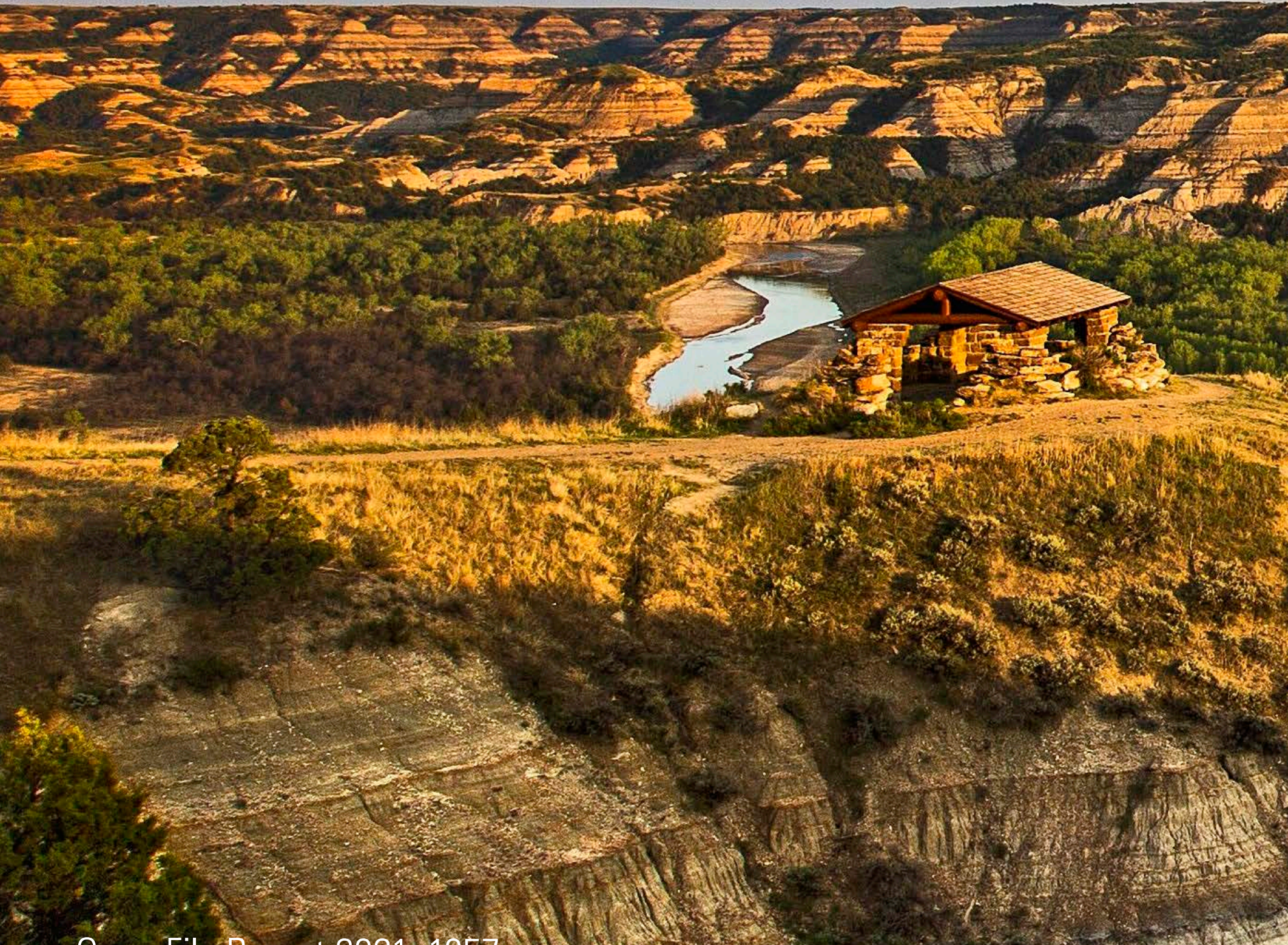

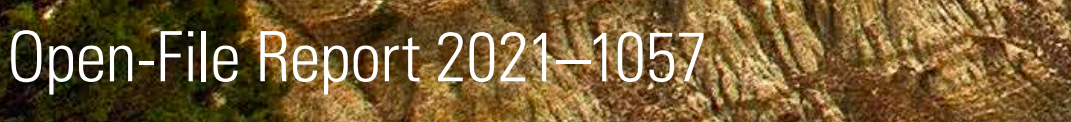

U.S. Department of the linterior

U.S. Geological Survey 
Cover. River Bend overlook, Theodore Roosevelt National Park, North Dakota. National Park Service public domain image by Dave Bruner. 


\section{Mineral Resource Inventory of North Dakota}

By Stephen E. Box and Pamela M. Cossette

Prepared in cooperation with Bureau of Land Management

Open-File Report 2021-1057 


\section{U.S. Geological Survey, Reston, Virginia: 2021}

For more information on the USGS — the Federal source for science about the Earth, its natural and living resources, natural hazards, and the environment-visit https://www.usgs.gov or call 1-888-ASK-USGS.

For an overview of USGS information products, including maps, imagery, and publications, visit https://store.usgs.gov.

Any use of trade, firm, or product names is for descriptive purposes only and does not imply endorsement by the U.S. Government.

Although this information product, for the most part, is in the public domain, it also may contain copyrighted materials as noted in the text. Permission to reproduce copyrighted items must be secured from the copyright owner.

Suggested citation:

Box, S.E., and Cossette, P.M., 2021, Mineral resource inventory of North Dakota: U.S. Geological Survey Open-File Report 2021-1057, 42 p., https://doi.org/10.3133/ofr20211057.

ISSN 2331-1258 (online) 


\section{Acknowledgments}

We would like to acknowledge Nathan Arave of the Bureau of Land Management and Thomas Frost of the U.S. Geological Survey (USGS) for their support for undertaking this mineral inventory.

We would also like to recognize the North Dakota Geological Survey, whose studies formed the foundation of this report. Reviews of the report and its digital underpinnings by Michael Zientek, Allen Anderson, and John Wallis (all USGS) substantially improved the presentation of this report and are greatly appreciated.

We thank Timothy Herold (USGS) for his skilled edit. 


\section{Contents}

Acknowledgments .......................................................................................................................ii

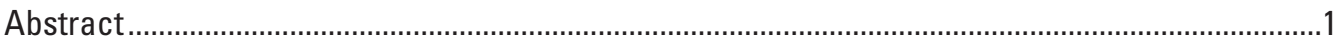

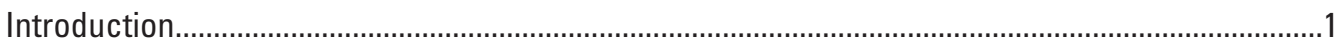

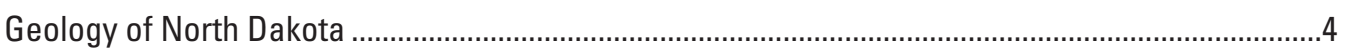

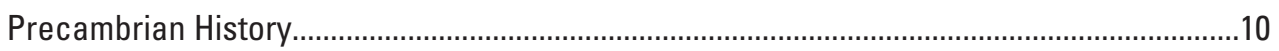

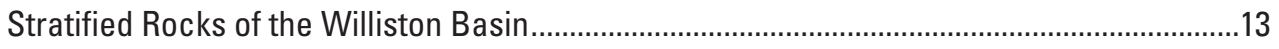

Ice Age Glacial Deposits of North Dakota............................................................................

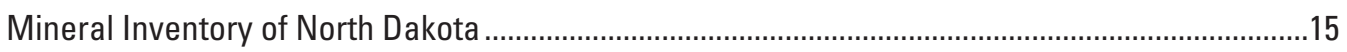

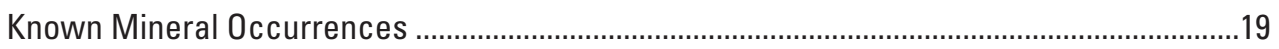

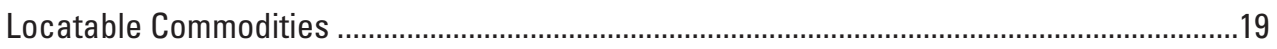

Potential Ore Deposits in the Crystalline Basement Rocks, Easternmost

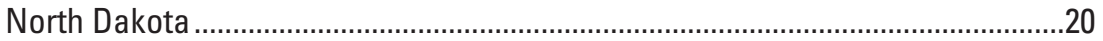

Potential Locatable Critical Mineral Occurrences in Phanerozoic

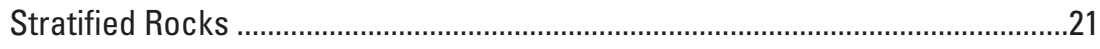

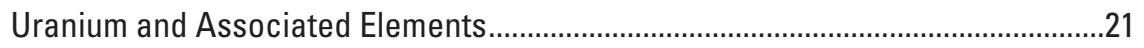

Rare Earth Elements and Germanium in Coal or Coal Fly Ash ................................21

Diamond-Bearing Kimberlite Pipes .....................................................................

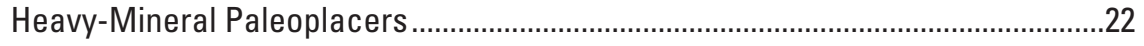

Other Potential Near-Surface Locatable Commodities..................................................22

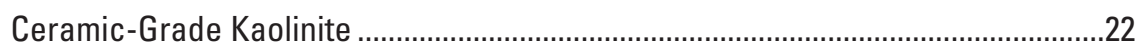

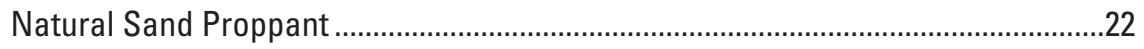

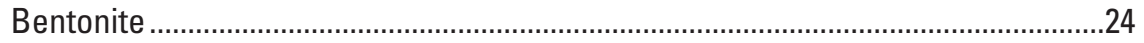

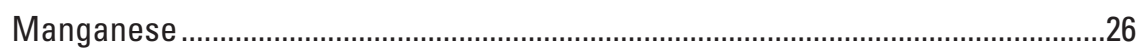

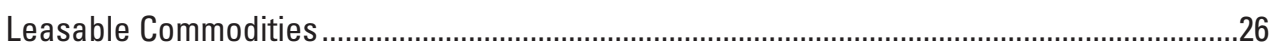

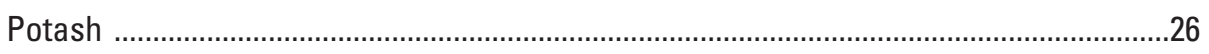

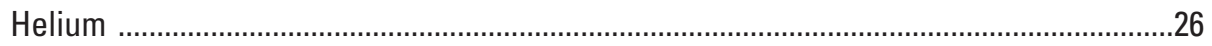

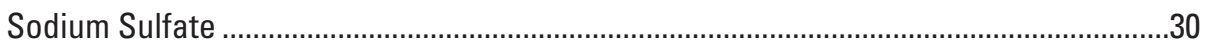

Salable Commodities...........................................................................................................

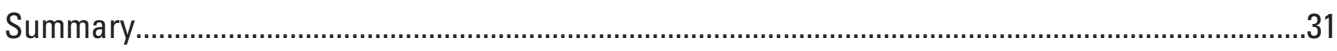

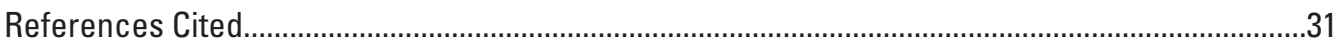

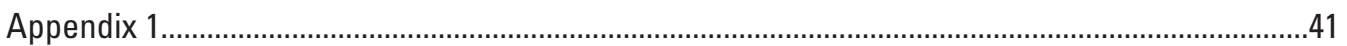

\section{Figures}

1. Map of North Dakota showing counties, cities, major highways, and railroads...............2

2. Map of North Dakota showing Federal and State surface land-management areas.......3

3. Shaded-relief map showing physiographic provinces of North Dakota .............................

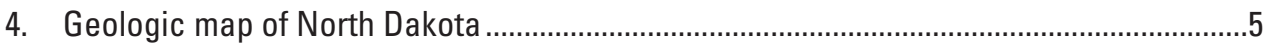

5. Map showing depth to pre-Quaternary bedrock in North Dakota ....................................6

6. Pre-Quaternary bedrock geologic map of North Dakota ...................................................

7. Generalized stratigraphic column of North Dakota ..............................................................

8. Map showing depth to crystalline basement and the depocenter and approximate eastern margin of the Williston Basin in North Dakota. 
9. Magnetic-anomaly map of North Dakota showing Precambrian basement terranes ...10

10. Isostatic-gravity map of North Dakota showing Precambrian basement terranes .........11

11. Simplified Quaternary glacial geologic map of North Dakota ......................................13

12. Map showing Bureau of Land Management mineral-use authorizations for nonenergy solid minerals in western part of North Dakota and only recorded mining claims in western North Dakota...

13. Shaded-relief physiographic map of North Dakota, showing mines, prospects, and occurrences of coal, lignite, uranium, and other mineral commodities, as well as outlines of uranium deposits.

14. Shaded-relief physiographic map of North Dakota, showing sand and gravel, clay pits and stone quarries.

15. Magnetic-anomaly map showing exploratory test wells into Precambrian basement rocks in eastern North Dakota

16. Shaded-relief map showing distribution of two kaolinite-rich horizons in southwestern North Dakota, the Bear Den Member and the Rhame bed..

17. Shaded-relief map showing distribution of eolian dune sands in North Dakota, which are potential sources of oil-field hydraulic-fracture proppant.

18. Map showing distribution of major known bentonite beds in southwestern North Dakota, overlain on geologic map

19. Map showing sub-surface distribution of members of the Prairie Formation in northwestern North Dakota where potash thickness is greater than 9 feet and $\mathrm{K}_{2} \mathrm{O}$ content is about 10 percent or greater.

20. Map showing helium production wells in Saskatchewan, Canada, in and adjacent to Williston Basin

21. Map showing helium gas concentrations in drill holes by stratigraphic unit in North Dakota

22. Shaded-relief map showing distribution of major sodium sulfate deposits in lakes in northwestern North Dakota

\section{Tables}

1. Mineral commodities considered by this mineral inventory of North Dakota and their principal and subsidiary deposit types, environments of mineral-deposit genesis, and potential in North Dakota...

2. Federal and State surface land-management areas in North Dakota

3. Mining claims reported by Bureau of Land Management LR2000 database for North Dakota . 


\section{Abbreviations}

\begin{tabular}{|c|c|}
\hline $\mathrm{Ag}$ & silver \\
\hline Al & aluminum \\
\hline As & arsenic \\
\hline $\mathrm{Au}$ & gold \\
\hline $\mathrm{Bi}$ & bismuth \\
\hline BLM & Bureau of Land Management \\
\hline C & carbon \\
\hline Co & cobalt \\
\hline Cs & cesium \\
\hline $\mathrm{Cu}$ & copper \\
\hline ERP & Energy Resources Program \\
\hline $\mathrm{Fe}$ & iron \\
\hline FIPS & Federal Information Processing Standards \\
\hline Fm. & Formation \\
\hline FWS & Fish and Wildlife Service \\
\hline GAPI & American Petroleum Industry gamma ray unit \\
\hline Grp. & Group \\
\hline IA & lowa \\
\hline IOCG & iron-oxide copper gold \\
\hline K & potassium \\
\hline k.y. & thousand years \\
\hline Li & lithium \\
\hline LR2000 & Legacy Rehost System database \\
\hline $\mathrm{Ma}$ & mega-annum \\
\hline MAS/MILS & Mineral Availability System/Mineral Industry Location System database \\
\hline $\mathrm{mGal}$ & milligals \\
\hline $\mathrm{Mn}$ & manganese \\
\hline MN & Minnesota \\
\hline Mo & molybdenum \\
\hline MRDS & Mineral Resource Data System \\
\hline MT & Montana \\
\hline m.y. & million years \\
\hline $\mathrm{N}$ & nitrogen \\
\hline NAD 1983 & North American Datum of 1983 \\
\hline NDAML & North Dakota Abandoned Mine Lands database (maintained by North Dakota) \\
\hline NDGS & North Dakota Geological Survey \\
\hline $\mathrm{Ni}$ & nickel \\
\hline nT & nanoteslas \\
\hline 0 & oxygen \\
\hline
\end{tabular}




$\begin{array}{ll}\text { ON } & \text { Ontario } \\ \mathrm{Pb} & \text { lead } \\ \mathrm{PGE} & \text { platinum group elements } \\ \mathrm{ppm} & \text { parts per million } \\ \mathrm{REE} & \text { rare earth elements } \\ \mathrm{Sn} & \text { tin } \\ \mathrm{Ta} & \text { tantalum } \\ \mathrm{Th} & \text { thorium } \\ \text { U } & \text { uranium } \\ \text { USFS } & \text { U.S. Forest Service } \\ \text { USGS } & \text { U.S. Geological Survey } \\ \text { USMIN } & \text { U.S. Mineral Deposit Database } \\ \text { V } & \text { vanadium } \\ \text { WY } & \text { Wyoming } \\ \text { yr } & \text { years } \\ \text { Zn } & \text { zinc } \\ \text { Zr } & \text { zirconium }\end{array}$





\title{
Mineral Resource Inventory of North Dakota
}

\author{
By Stephen E. Box and Pamela M. Cossette
}

\section{Abstract}

Aside from construction aggregate materials, the value of nonfuel mineral commodities that have been produced in North Dakota is small, although there is potential for the existence of several mineral resource deposit types which are not economically viable at this time. In this report, we present a mineral resource inventory of the State of North Dakota, developed by the U.S. Geological Survey at the request the Bureau of Land Management. To set the stage for that inventory, we briefly outline the long and complex geologic history of North Dakota that extends back more than 3 billion years. Using several existing databases, we summarize the distribution of known mineral commodities and the results of commodity exploration over time. Using all available data, we discuss the potential for economic occurrences of 13 commodities in North Dakota, including some listed as Critical Minerals.

\section{Introduction}

This report represents a mineral resource inventory for the State of North Dakota (fig. 1), developed by the Mineral Resources Program staff of the U.S. Geological Survey (USGS) at the request the U.S. Bureau of Land Management (BLM). The BLM request stated

"The mineral resource inventory will include Critical Minerals as listed in the Federal Register (May 18, 2018), along with sodium, frac sand, bentonite and ceramic grade kaolinite. Rare earth elements, lithium and potash are included in the Federal Register list. A review will also be conducted on selected leasable and salable mineral commodities based on information provided by the BLM and the North Dakota Geological Survey. Coal, oil and gas, leonardite, and uranium are commodities under the purview of the Energy Resources Program (ERP) of the USGS, which is submitting a separate proposal to address those commodities... As requested by the BLM, the expected report will be an inventory of available information for mineral occurrences and not include an assessment of mineral resource potential."

Only previously published data have been used for this report. The last substantial evaluation of the mineral resources of North Dakota was completed in 1973 by the USGS and the U.S. Bureau of Reclamation in collaboration with the North Dakota Geological Survey (NDGS) and the U.S. Bureau of Mines (Landis, 1973). Commodities considered during this study include Critical Minerals as listed in the Federal Register (May 18, 2018), along with sodium sulfate, "frac" or fracture-proppant sand, bentonite, and ceramic-grade kaolinite. Other selected leasable and salable mineral commodities will also be inventoried on the basis of information provided to the USGS by BLM (see table 1, located after the "References Cited"). Coal, oil and gas, leonardite, and uranium are being inventoried in a separate report prepared by the Energy Resources Program of the USGS. A map of surface landmanagement areas by Federal and State agencies, including the BLM, in North Dakota is shown in figure 2, and acreages are tabulated in table 2, located after the "References Cited."

The report begins with an overview of the geology of North Dakota to provide context for the State's known mineral commodity occurrences. This is followed by an inventory of the known mineral commodity occurrences from the BLM Legacy Rehost System database (LR2000) and other publicly available mineral occurrence databases. These and other mineral commodities previously identified in the State are further discussed in terms of their probable locations, controlling geologic factors, and any exploration history. In this report, the stratigraphic classification of the NDGS is used (Clayton and others, 1977; Murphy and others, 2009). The commodities are separated into locatable, leasable, and salable resources for discussion.

\section{Geology of North Dakota}

North Dakota is situated in the Northern Great Plains physiographic province of the North American continent (Wayne and others, 1991; Waldkirch, 1999; fig. 3, this report). The topography is generally of low relief: the 

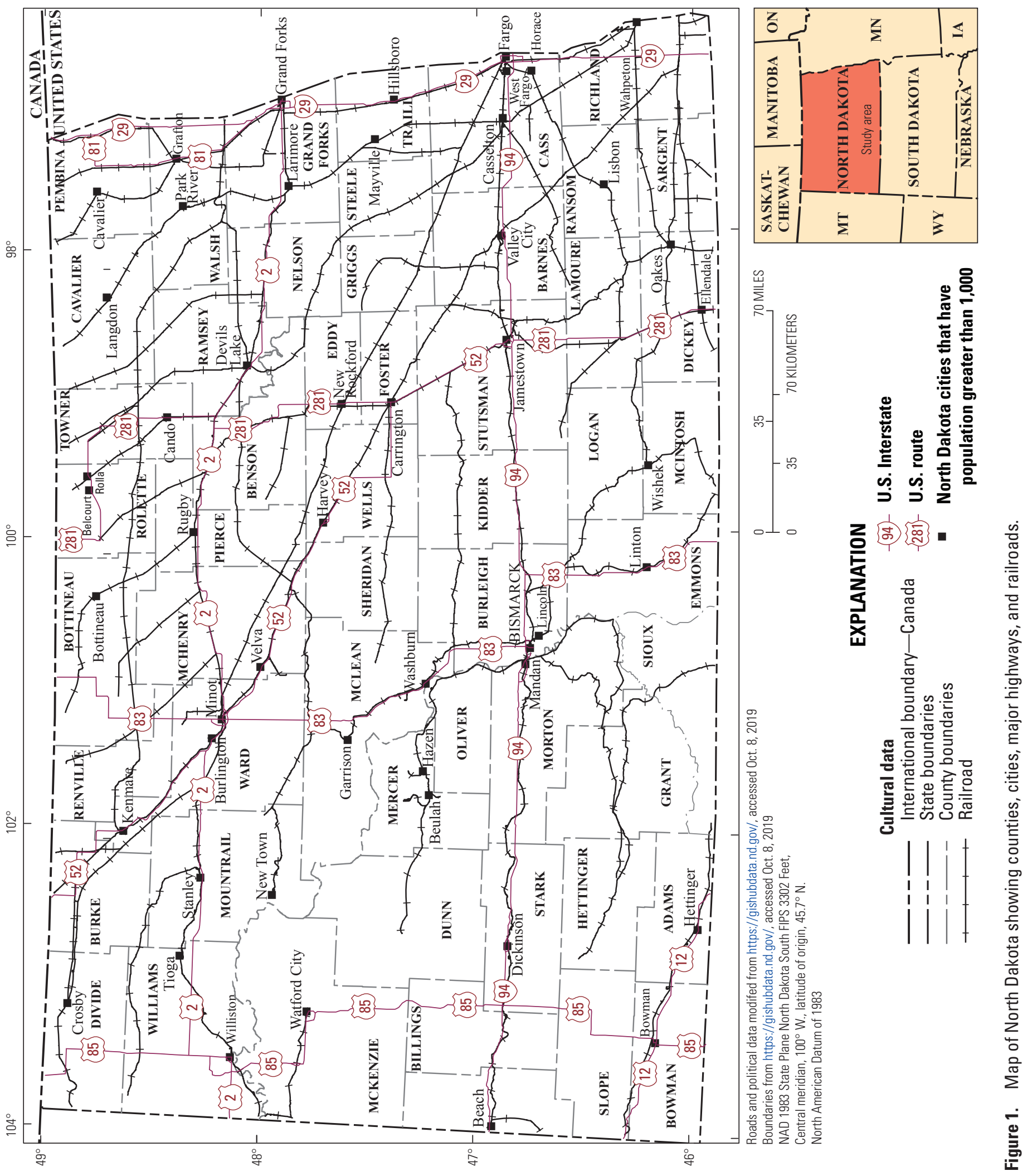


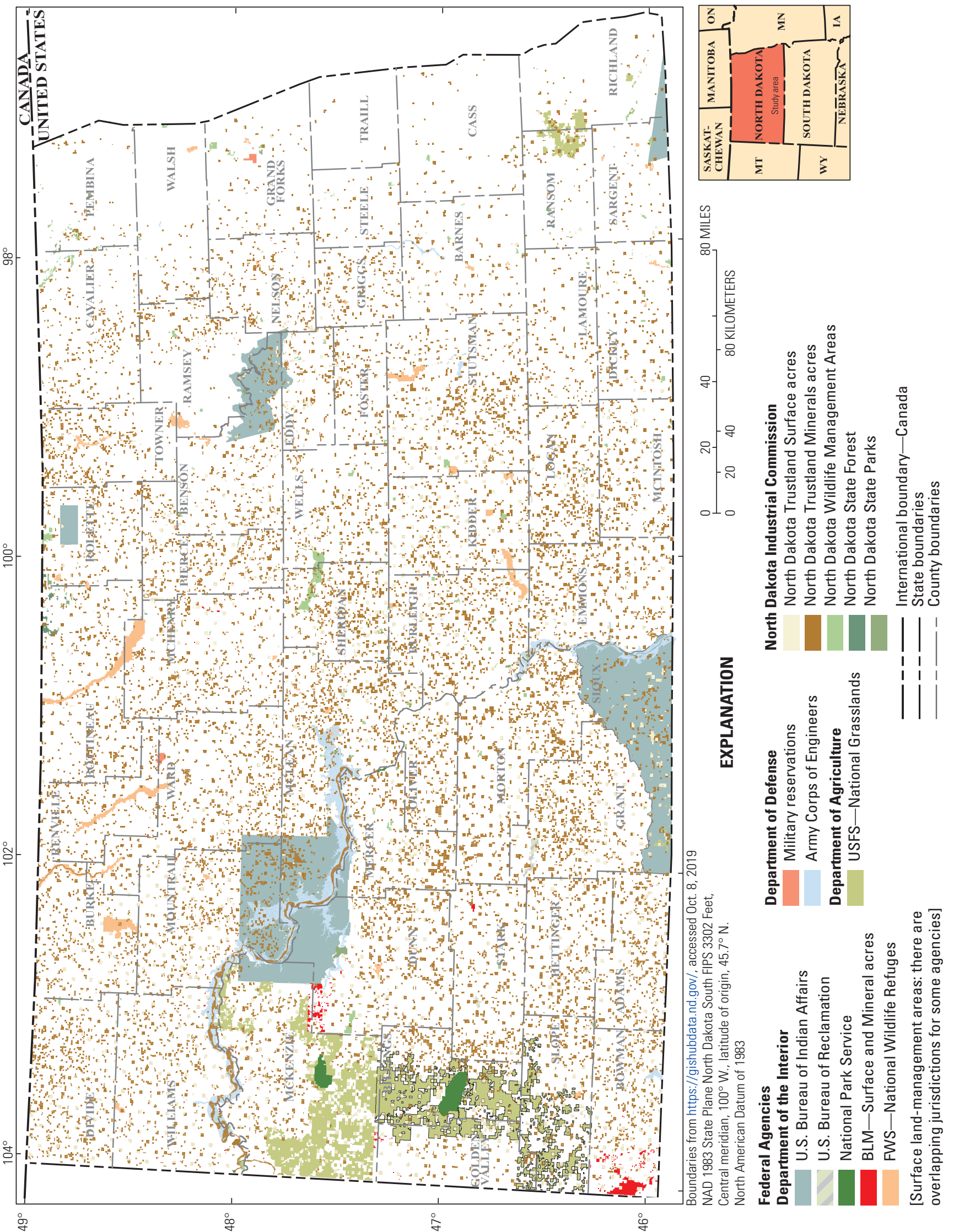

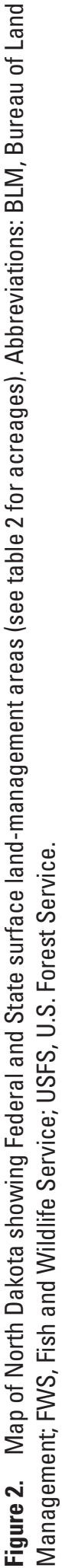


highest elevation, 1,069 meters $(\mathrm{m})(3,506$ feet [ $\mathrm{ft}])$, is in the southwest quarter of the State (Missouri Slope and Mackenzie Uplands provinces); the lowest elevation, $229 \mathrm{~m}$ (750 ft), is in the Red River of the North Valley along the eastern State boundary at the Canadian border. The Little Missouri River cuts northward through the uplands, with the Little Missouri Badlands along its flanking tributaries. The Missouri River flows from Montana into the northwest quarter of North Dakota, cutting southeastward to leave the State near the center of its border with South Dakota. The Missouri Coteau province is a broad hilly upland forming a divide between the Missouri River to the west and the Central Lowland province to the east. The Missouri Escarpment is an abrupt boundary between the Missouri Coteau and the flat Central Lowland.
Two broad circular lake basins (Devils Lake and Souris Lake basins) in the northern part of the Central Lowland separate northward-flowing (Souris River) and southward-flowing (James River, Beaver Creek) river systems. A gentle northsouth-trending escarpment (Pembina Escarpment) separates the Central Lowland from the valley of the north-flowing Red River of the North to the east. The Red River of the North forms the State boundary with Minnesota to the east.

About three-quarters of the surface area of the State (that is, its southeastern, northeastern, and northwestern parts) consists of unconsolidated Quaternary (deposited in the last 2.6 million years [m.y.]) sediments, mostly of glacial origin (Clayton and others, 1980a, b; fig. 4, this report). The unconsolidated Quaternary sediments are of variable thickness

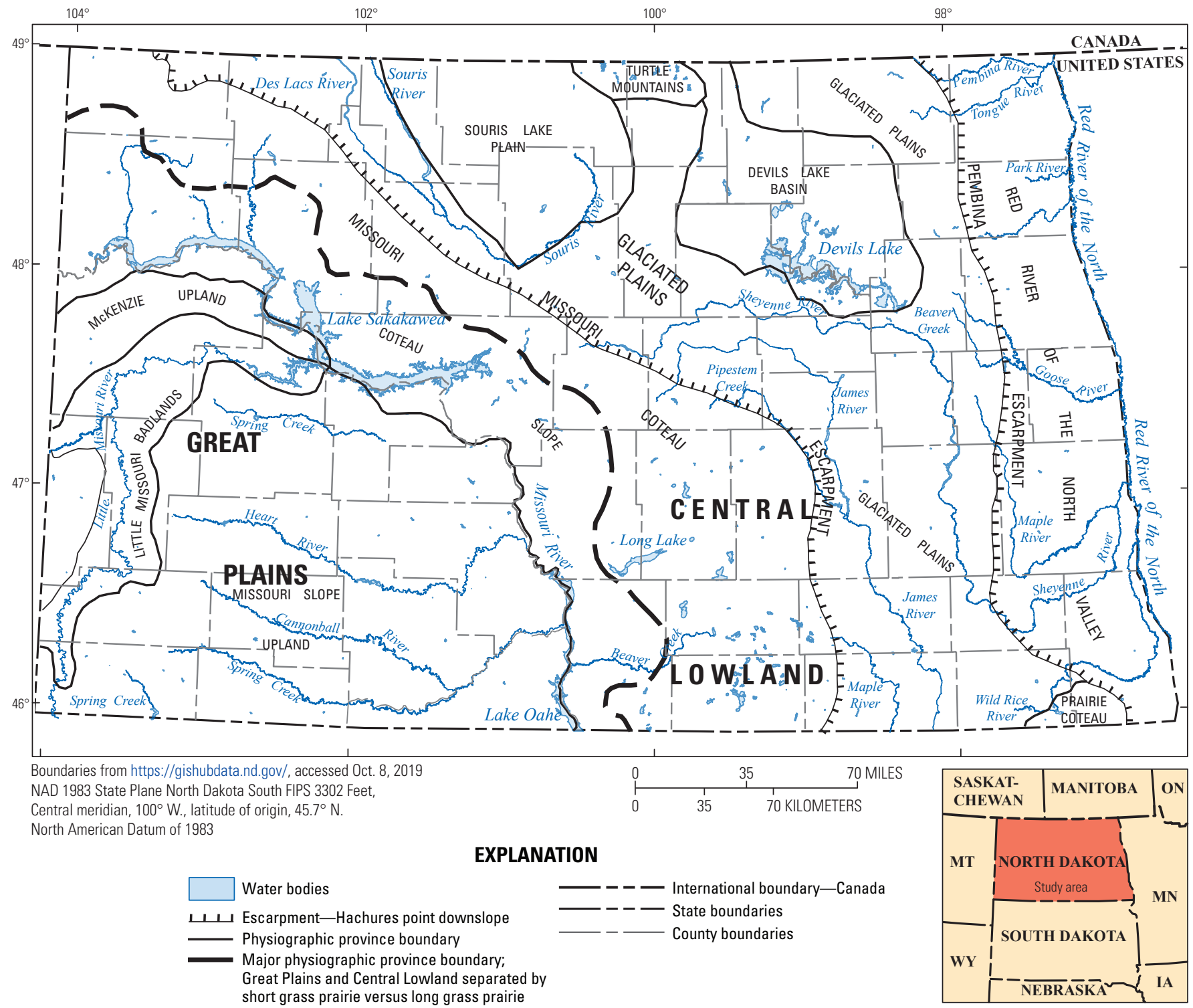

Figure 3. Shaded-relief map showing physiographic provinces of North Dakota (from Bluemle, 1977; Waldkirch, 1999), as well as major rivers and lakes. North Dakota is traditionally divided into Great Plains and Central Lowland provinces on the basis of prairie coverage by short and medium grasses versus long grasses, respectively, prior to European settlement. 


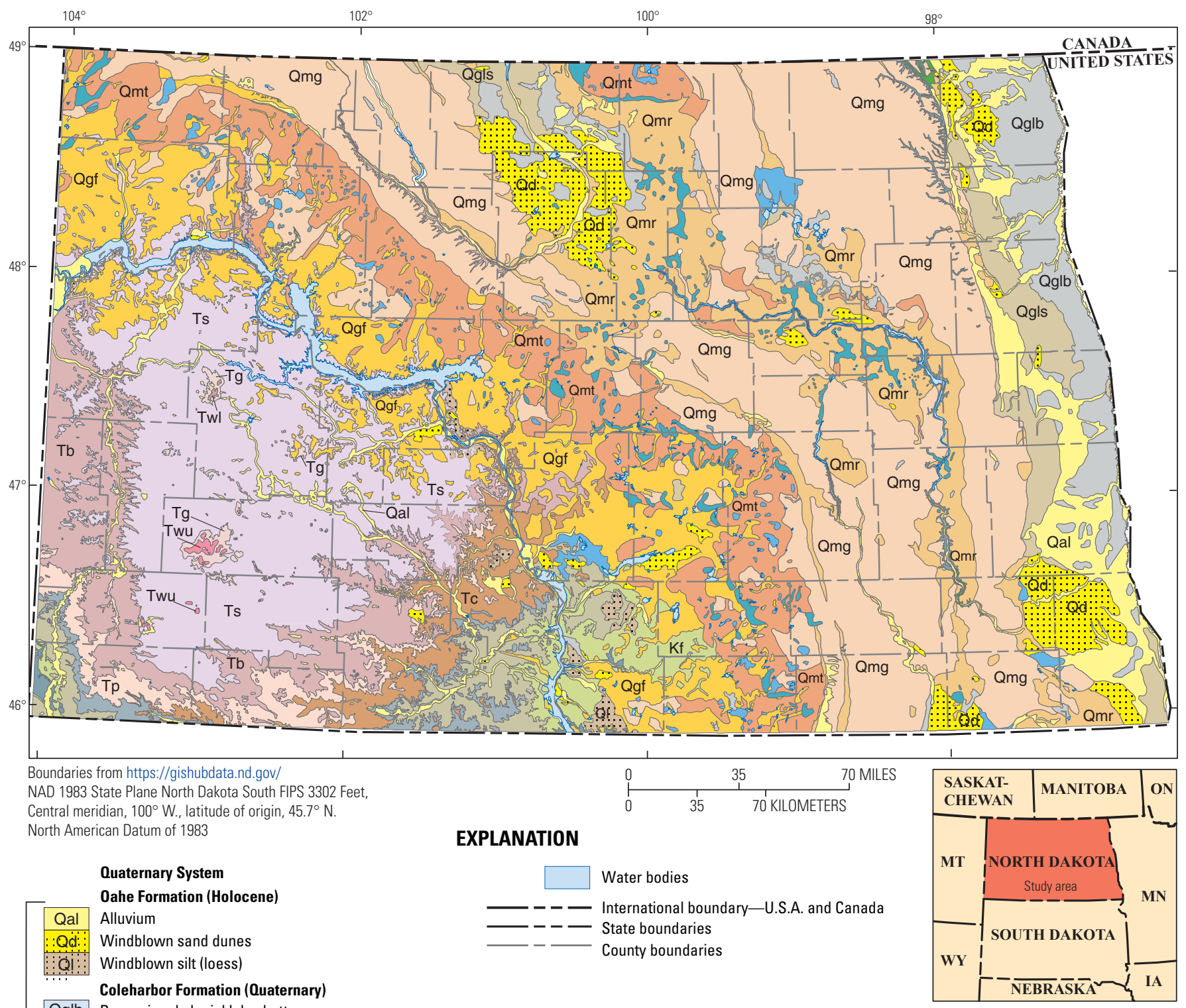

\section{Tertiary System}

Twu White River Group, Upper-Pinkish river and lake sediments, mainly siltstone

TwI White River Group, Lower-Pale river and lake sediments, mainly sandstone

$\mathrm{Tg}$ Golden Valley Formation-Yellowish-brown river, lake, and swamp deposits that have thin lignite and locally kaolinitic claystone Sentinel Butte Formation-Somber grayish-brown river, lake, and swamp deposits that have bentonitic clays and lignite Bullion Creek Formation-Brightly colored river, lake, and swamp deposits that have bentonitic clays and lignite Slope Formation-Dark river, lake, and swamp deposits that have lignite and kaolinitic claystones

Ludlow Formation - Gray river, lake, and swamp deposits that have lignite and kaolinitic claystones Cretaceous System Fox Hills Formation-Dark reddish -rown marine mudstone and yellow-brown sandstone Pierre Formation-Gray marine shale that have thick bentonite near base Niobrara and Carlile Formation, undivided - Gray calcareous marine shale

Figure 4. Geologic map of North Dakota. Quaternary units modified from Clayton and others $(1980 \mathrm{a}, \mathrm{b})$; Cretaceous and Tertiary units modified from Bluemle (1983). Stratigraphic classification from Clayton and others (1977), Murphy and others (2009). Cratonic sequences (CS-5, Zuni sequence [180$50 \mathrm{Ma}$; $\mathrm{CS}-6$, Tejas sequence [40-0 Ma]) are separated by about 10 m.y. of erosion. 
(Soller and Garrity, 2018; fig. 5, this report). In the southwestern part of the State, Upper Cretaceous (100-65 megaannum [Ma]) marine strata and Tertiary (65-2.6 Ma) nonmarine strata crop out at the surface. The bedrock geologic map in figure 6 shows the rocks at the surface with the unconsolidated sediments removed (see also, Bluemle, 1983).

North Dakota is part of the Northern Great Plains province of North America (Wayne and others, 1991), which is a stable platform underpinned by plutonic and metamorphic cratonic basement rocks at depth and overlain by variable thicknesses of little-deformed Phanerozoic (540 Ma to the present) sedimentary rocks and sediment (Murphy and others, 2009; fig. 7, this report). Depth to basement varies from less than $100 \mathrm{~m}$ (a few hundred feet) along the eastern boundary of the State to about 5,000 $\mathrm{m}(>15,000 \mathrm{ft})$ at the thickest part of the Williston Basin near the western State boundary (Anderson, 2009; fig. 8, this report). During the last glacial period of the Ice Age (last 0.1 Ma), the Laurentide ice sheet, which covered

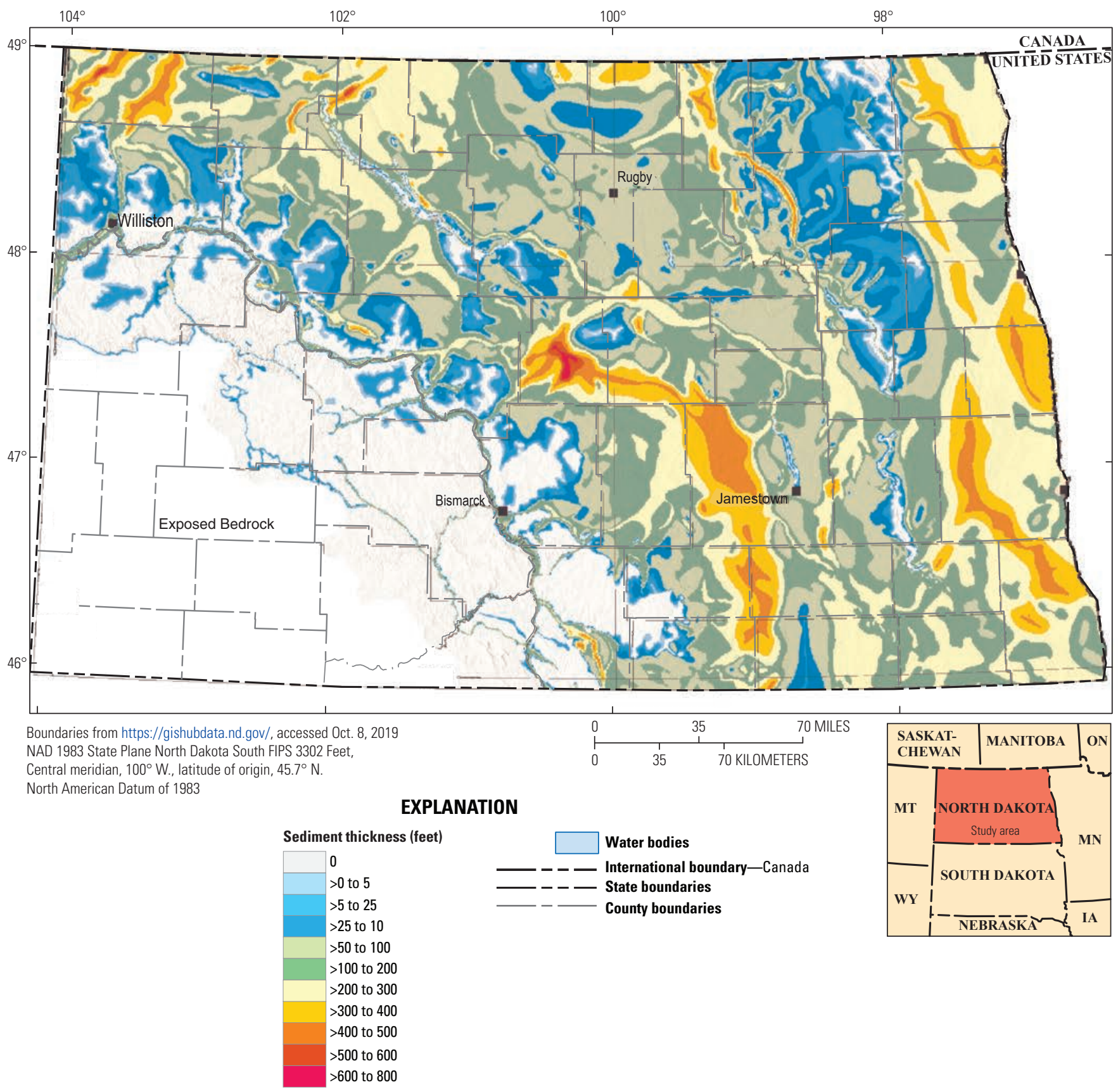

Figure 5. Map showing depth to pre-Quaternary bedrock in North Dakota (modified from Soller and Garrity, 2018). 


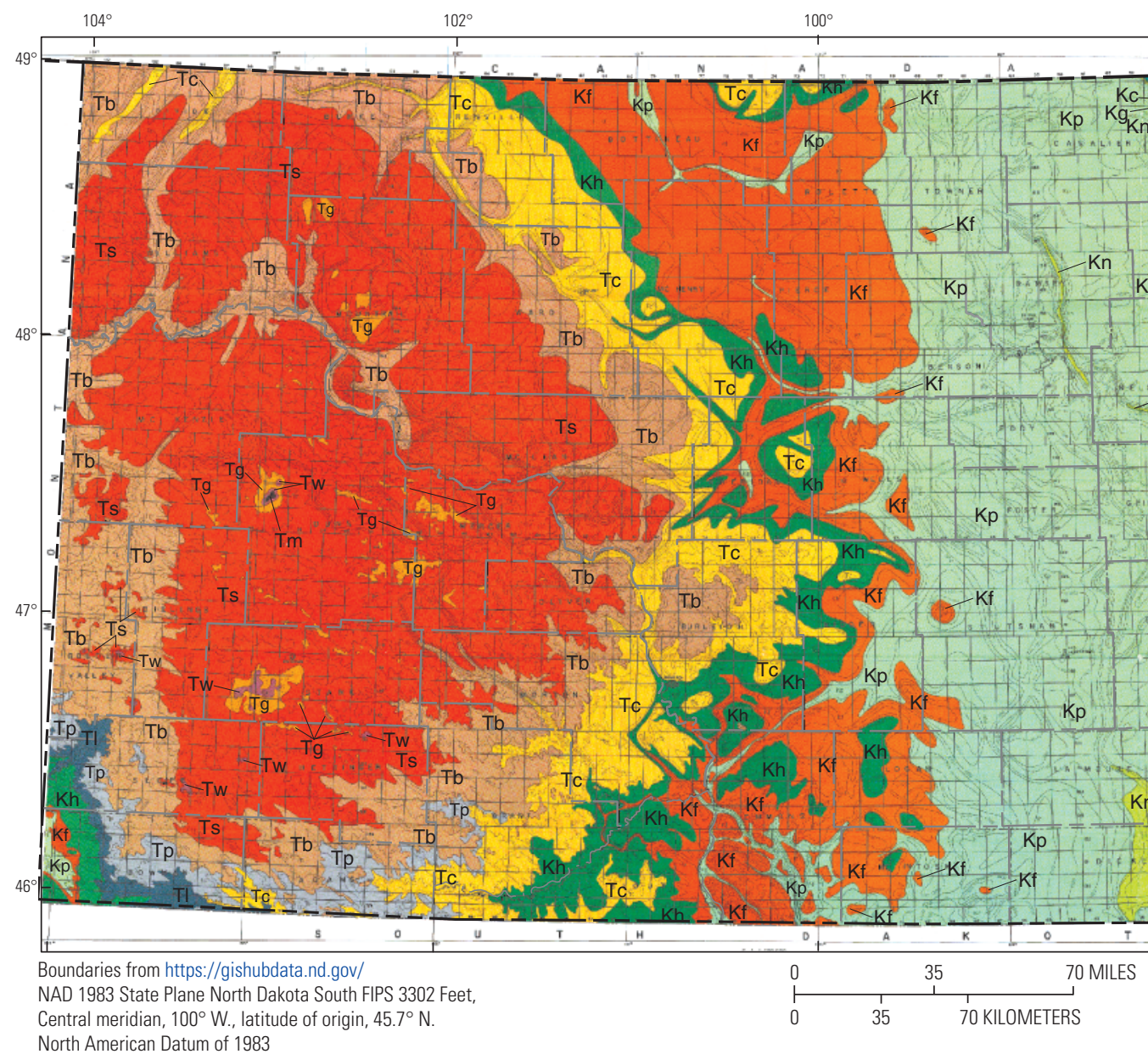

North American Datum of 1983

\section{EXPLANATION}

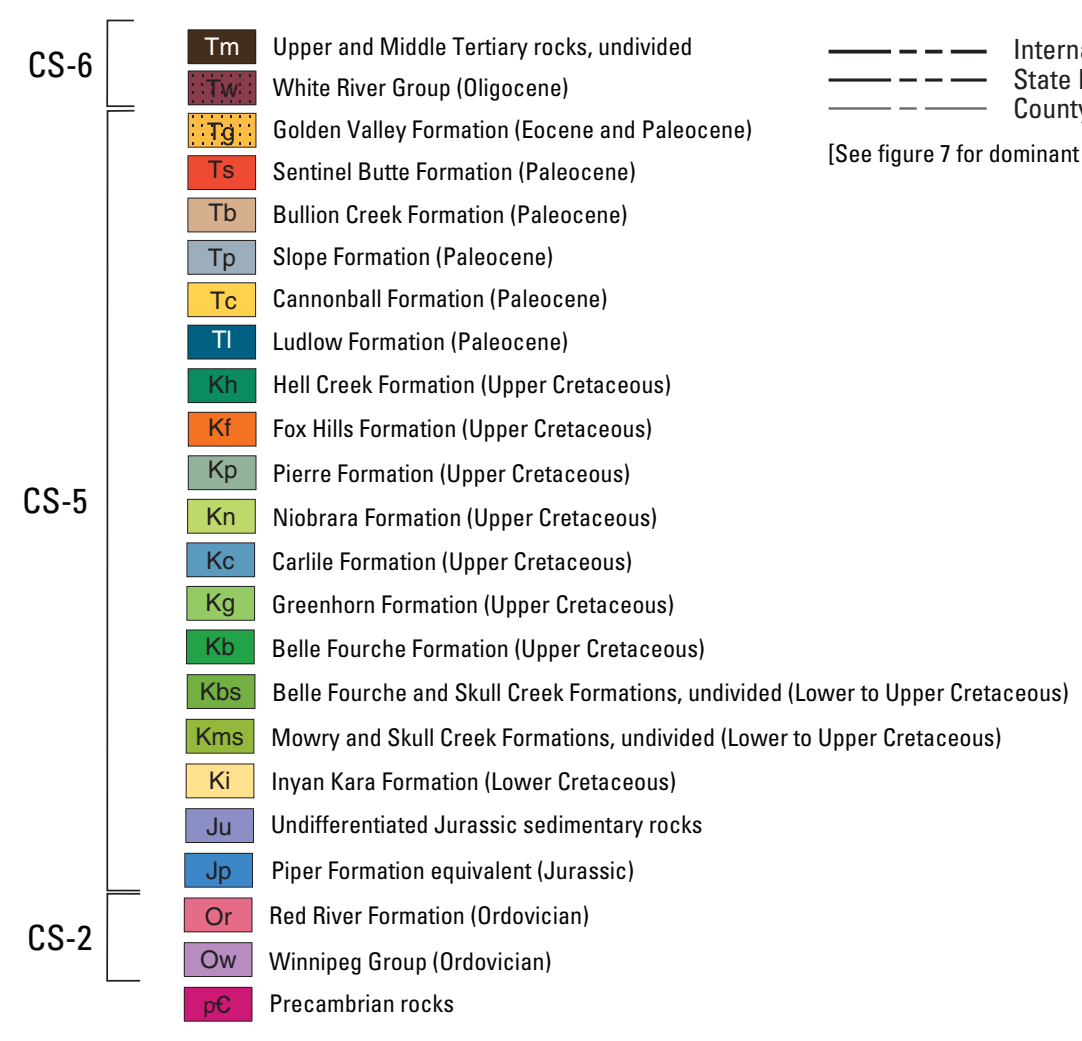

Figure 6. Pre-Quaternary bedrock geologic map of North Dakota (from Bluemle, 1987). Stratigraphic classification from Clayton and others (1977), Murphy and others (2009). Cratonic sequences: CS-2, Tippecanoe sequence (460-430 Ma); CS-5, Zuni sequence (180-50 Ma); CS-6, Tejas sequence (40-0 Ma).

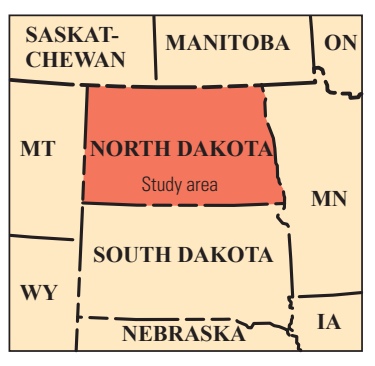




\begin{tabular}{|c|c|c|c|c|c|c|c|c|c|c|}
\hline $\begin{array}{c}\text { Age } \\
\text { (million } \\
\text { years) }\end{array}$ & Era & \multicolumn{2}{|c|}{ System } & Series & $\begin{array}{l}\text { Cratonic } \\
\text { sequence }\end{array}$ & $\begin{array}{c}\text { Sloss } \\
\text { (1963) } \\
\text { sequence }\end{array}$ & Group & Formation & $\begin{array}{c}\text { Max } \\
\text { thickness } \\
\text { feet (m) }\end{array}$ & Dominant lithology \\
\hline \multirow{2}{*}{$-0.01-$} & \multirow{12}{*}{$\begin{array}{l}\text { U } \\
\text { N } \\
\text { Oे } \\
\text { U్ }\end{array}$} & \multirow{2}{*}{\multicolumn{2}{|c|}{ 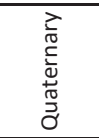 }} & Holocene & \multirow{6}{*}{ CS-6 } & \multirow{6}{*}{$\frac{\mathscr{n}}{\tilde{\sigma}}$} & & Oahe & $100(30)$ & River, lake, and dune deposits \\
\hline & & & & Pleistocene & & & Coleharbor & & $1000(300)$ & Glacial deposits \\
\hline \multirow{2}{*}{$\begin{array}{l}-2.6- \\
-5.3-\end{array}$} & & \multirow{10}{*}{ 告 } & \multirow{2}{*}{ 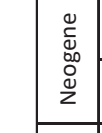 } & Pliocene & & & & (unnamed) & $300(91)$ & Gravel, sand, clay \\
\hline & & & & Miocene & & & & Arikaree & $330(101)$ & Tuffaceous limestone, sand, silt \\
\hline \multirow{8}{*}{$-23-1$} & & & & Oligocene & & & White & Brule & $200(61)$ & Siltstone, claystone \\
\hline & & & & Encene & & & River & Chadron & $140(43)$ & Sandstone, conglomerate \\
\hline & & & & Luctic & & & & Golden Valley & $400(122)$ & Sandstone, silt-mudstone \\
\hline & & & 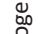 & & & & & Sentinel Butte & 650 (198) & Sandstone, mudstone, lignite \\
\hline & & & $\frac{0}{\underline{0}}$ & & & & & Bullion Creek & 650 (198) & Sandstone, mudstone, lignite \\
\hline & & & & Paleocene & & & Fort Union & Slope & $270(82)$ & Sandstone, mudstone, lignite \\
\hline & & & & & & & & Cannonball & $255(78)$ & Mudstone, sandstone \\
\hline & & & & & & & & Ludlow & 300 (91) & Sandstone, mudstone, lignite \\
\hline 00 & & & & & & & & Hells Creek & $330(101)$ & Sandstone, mudstone, lignite \\
\hline & & & & & & & Montana & Fox Hills & 400 (122) & Sandstone, silt-mudstone \\
\hline & & & & & & & & Pierre & $2,300(701)$ & Non-calcareous shale \\
\hline & & & & Upper & CS-5 & $\subsetneq$ & & Niobrara & $250(76)$ & Calcareous shale \\
\hline & & & & & S & 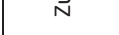 & Colorado & Carlile & $400(122)$ & Non-calcareous shale \\
\hline & & & & & & & & Greenhorn & $150(46)$ & Micaceous shale \\
\hline-100 & $\overline{\mathrm{o}}$ & & & & & & & Belle Fourche & 350 (107) & Shale, bentonitic clay \\
\hline & s & & & & & & & Mowry & 300 (91) & Shale, bentonitic clay \\
\hline & 岁 & & & Lower & & & Dakota & Newcastle & $150(46)$ & Sandstone \\
\hline & & & & & & & & Skull Creek & $140(43)$ & Shale, bentonitic clay \\
\hline-145 & & & & & & & & Inyan Kara & 625 (191) & Sandstone, shale \\
\hline & & & & & & & & Swift & $725(221)$ & Shale, calcareous sandstone \\
\hline & & & & assic & & & & Rierdon & $100(30)$ & Shale, limestone \\
\hline-201 - & & & & & & & & Piper & 625 (191) & Shale, limestone, gypsum \\
\hline$-252-$ & & & & assic & & & & Spearfish & 750 (229) & Siltstone, sandstone, mudstone, \\
\hline & & & & mian & & & & Minnekahta & $70(21)$ & Limestone \\
\hline & & & & (1) & & & & Opeche & 500 (152) & Shale, salt \\
\hline-299 & & & & & CS-4 & $\frac{2}{\circ}$ & & Broom Creek & 375 (114) & Sandstone, dolomite \\
\hline & & & 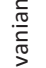 & & & $\frac{n}{4}$ & & Amsden & 450 (137) & Dolomite, shale, anhydrite \\
\hline & & 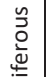 & $\begin{array}{l}\hat{n} \\
\text { टे } \\
\text { d } \\
0\end{array}$ & & & & ivinimetusa & Tyler & $270(82)$ & Shale, sandstone, limestone \\
\hline - & & 당 & $\frac{\sqrt{\sigma}}{\sigma}$ & & & & Big Snowy & Otter & $200(61)$ & Shale, limestone \\
\hline & & ปัँ & $\frac{0}{2}$ & & & & Dig disury & Kibbey & $250(76)$ & Sandstone, limestone, gypsum \\
\hline & & & $\overline{\frac{n}{n}}$ & & & & & Charles & & \\
\hline & & & $\stackrel{m}{\Sigma}$ & & & & Madison & Mission Canyon & $(753)$ & dolomite, salt \\
\hline $359-$ & & & & & & & & Bakken & $160(49)$ & Carbonaceous shale \\
\hline & N & & & & $C_{-3}$ & 竞 & & Three Forks & $270(82)$ & Limestone, dolomite, shale \\
\hline & 岸 & & & & כ- & 意 & Jefferson & Birdbear & $150(46)$ & Limestone, dolomite \\
\hline & & & & & & & 10 & Duperow & $535(163)$ & Limestone, dolomite, shale \\
\hline & & & & onian & & & Manitoba & Souris River & 375 (114) & Dolomite, limestone, shale \\
\hline & & & & & & & & Dawson Bay & $190(58)$ & Dolomite, limestone, shale \\
\hline & & & & & & & & Prairie & 650 (198) & Halite, potash, anhydrite \\
\hline & & & & & & & Elk Point & Winnepegosis & $220(67)$ & Limestone, dolomite, anhydrite \\
\hline & & & & & & & & Ashern & $180(55)$ & Limestone, dolomite, anhydrite \\
\hline (1) & & & & urian & & & & Interlake & $\mid 1,100(335)$ & Limestone, dolomite, anhydrite \\
\hline & & & & & & & & Stonewall & $120(37)$ & Limestone, dolomite \\
\hline & & & & & & $\stackrel{\circ}{\check{\infty}}$ & Big Horn & Stony Mountain & $250(76)$ & Dolomite, limestone \\
\hline & & & & & CS-2 & 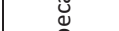 & & Red River & $700(213)$ & Limestone, dolomite \\
\hline & & & Ord & pvician & & $\stackrel{2}{2}$ & & Roughlock & $90(27)$ & Calcareous shale \\
\hline & & & & & & & Winnipeg & Icebox & $170(52)$ & Carbonaceous shale \\
\hline & & & & & & & & Black Island & $270(82)$ & Sandstone, shale \\
\hline$-485-$ & & & & abrian & CS-1 & 荡 & & Deadwood & $1,000(305)$ & Sandstone, limestone, shale \\
\hline & & & & & & cambri & & & & Gneiss, schist, granite \\
\hline
\end{tabular}

Figure 7. Generalized stratigraphic column of North Dakota (modified from Murphy and others, 2009). 
nearly all of Canada, advanced southward, covering all but the southwest one-third of North Dakota before melting and retreating about 12,000 years (yr) ago (Wayne and others, 1991).

In the following discussion of the geologic history of North Dakota, we begin with the history preserved in
Precambrian basement rocks and then continue with the history preserved in the strata of the Williston Basin, ending with the glacial and post-glacial history of the State. Geologic features relevant to the occurrence of economic commodities are noted in the discussion.

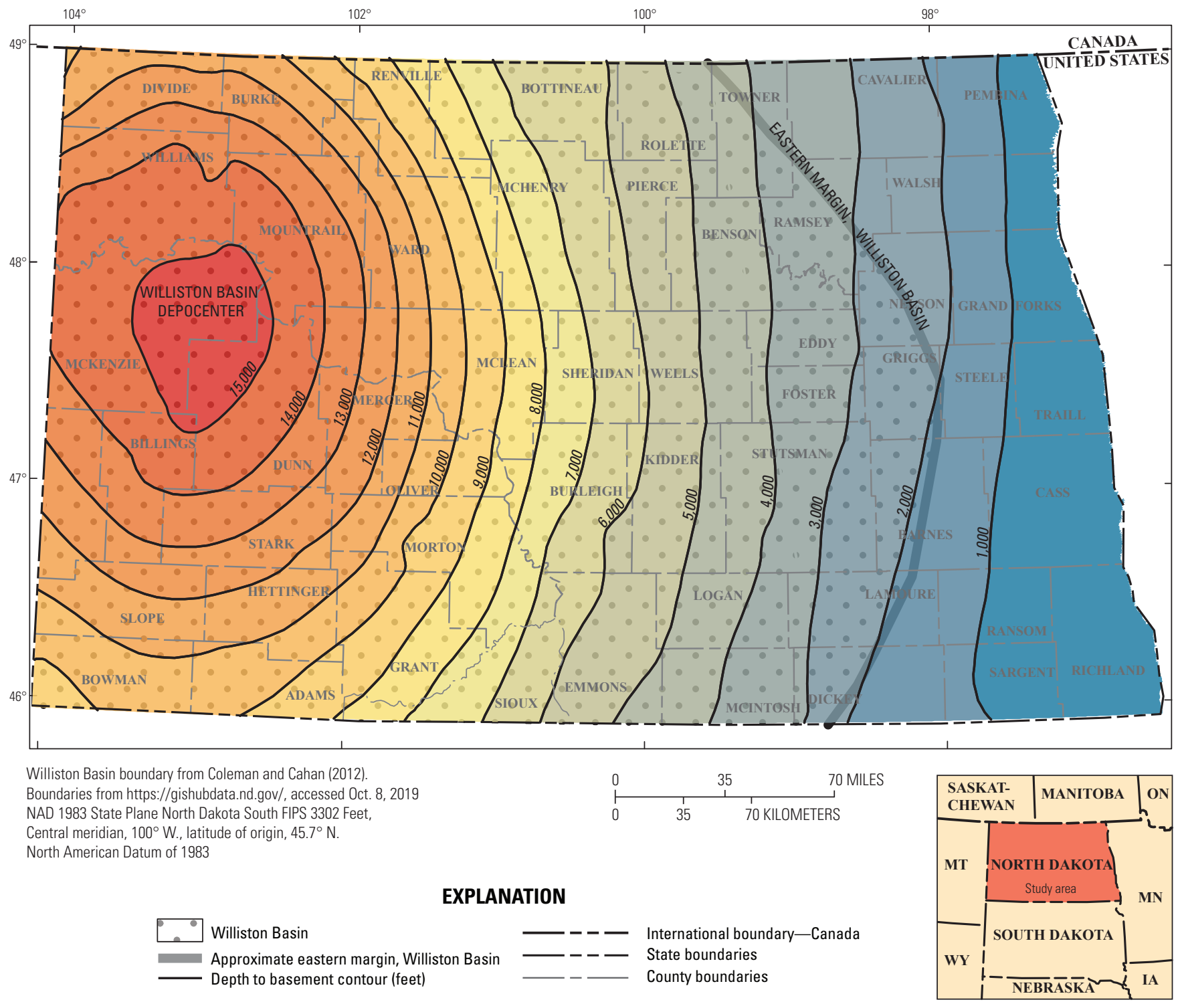

Figure 8. Map showing depth to crystalline basement (modified from Anderson, 2009) and the depocenter and approximate eastern margin of the Williston Basin (Coleman and Cahan, 2012) in North Dakota. 


\section{Precambrian History}

Precambrian basement rocks are not exposed at the surface in North Dakota but have been recovered from numerous wells and drill holes around the State. Characterization of these samples and regional geophysical data (both within and beyond the boundaries of North Dakota) have been used to map the Precambrian geologic provinces in the cratonic basement rocks (Sims and others, 1991; Nelson and others, 1993; Lewry and others, 1994; McCormick, 2010; Nesheim, 2012; Bader, 2019). Regional geophysical data are presented in figures 9 and 10, along with the boundaries of the inferred basement provinces (from McCormick, 2010, and Bader, 2019). An integrated map of aeromagnetic data (fig. 9) reveals the variable magnetic character of the deep basement rocks
(Sweeney and Hill, 2003). An integrated map of the isostatic gravity field (fig. 10) is sensitive to variations in rock density in the basement rocks (Sweeney and Hill, 2003).

Bader (2019) provided a review of the North Dakota Precambrian basement rocks and their history (see also, Sims and others, 1991; McCormick, 2010; Nesheim, 2012; Bedrosian and Finn, 2019). North Dakota is underlain by three different basement rock domains: the Superior craton, in the east half of the State; rocks formed during the Trans-Hudson orogeny, in most of the west half; and the Wyoming craton, in only the extreme southwest corner of the State (fig. 9). The Superior craton (which underlies eastern North Dakota) consists of alternating belts of weakly magnetic metasedimentary rocks (locally with banded-iron formation) and metamorphosed basaltic volcanic rocks, both of which have been intruded

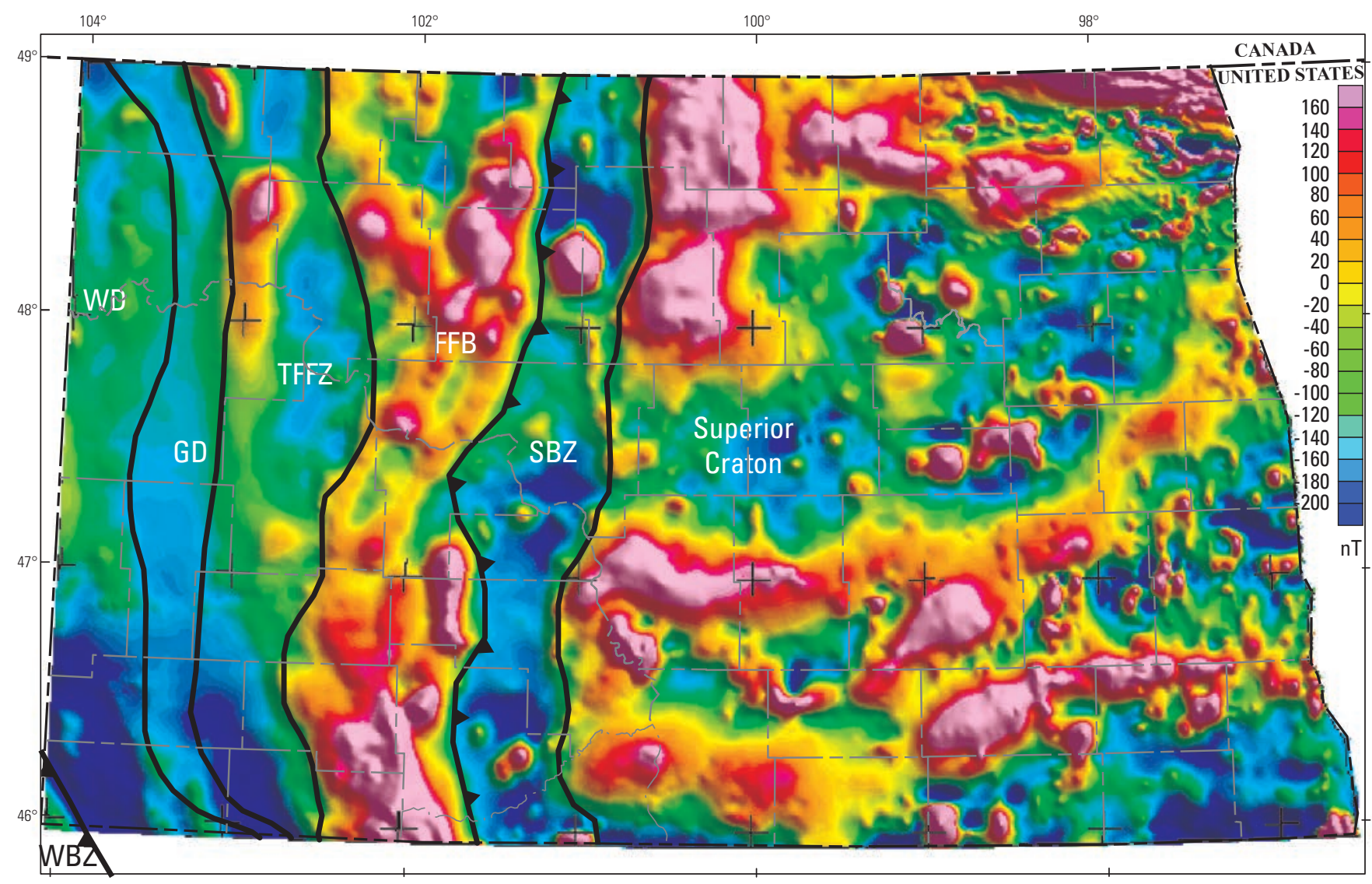

Boundaries from https://gishubdata.nd.gov/, accessed Oct. 8, 2019 NAD 1983 State Plane North Dakota South FIPS 3302 Feet, Central meridian, $100^{\circ} \mathrm{W}$., latitude of origin, $45.7^{\circ} \mathrm{N}$ North American Datum of 1983

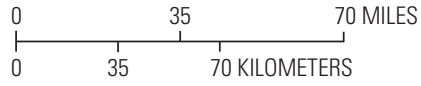

EXPLANATION

Configuration of Precambrian basement terranes
WBZ Wyoming boundary zone
$\begin{gathered}\text { Trans-Hudson } \\ \text { orogen }\end{gathered}\left[\begin{array}{ll}\text { WD } & \text { Williston domain } \\ \text { GD } & \text { Glennie domain } \\ \text { TFFZ Tabbernor fold and fault zone } \\ \text { FFB } & \text { Flin Flon belt } \\ \text { SBZ } & \text { Superior boundary zone }\end{array}\right.$

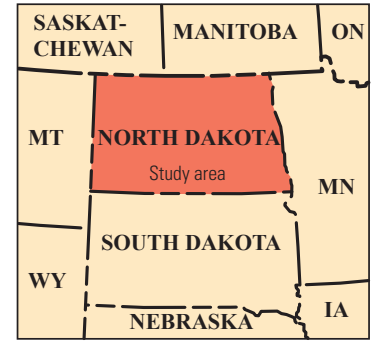

Figure 9. Magnetic-anomaly map of North Dakota (from Sweeney and Hill, 2003), upward continued to 1,000 feet and shaded with northeastern illumination. Precambrian basement terranes from Bader (2019). nT, nanoteslas. 

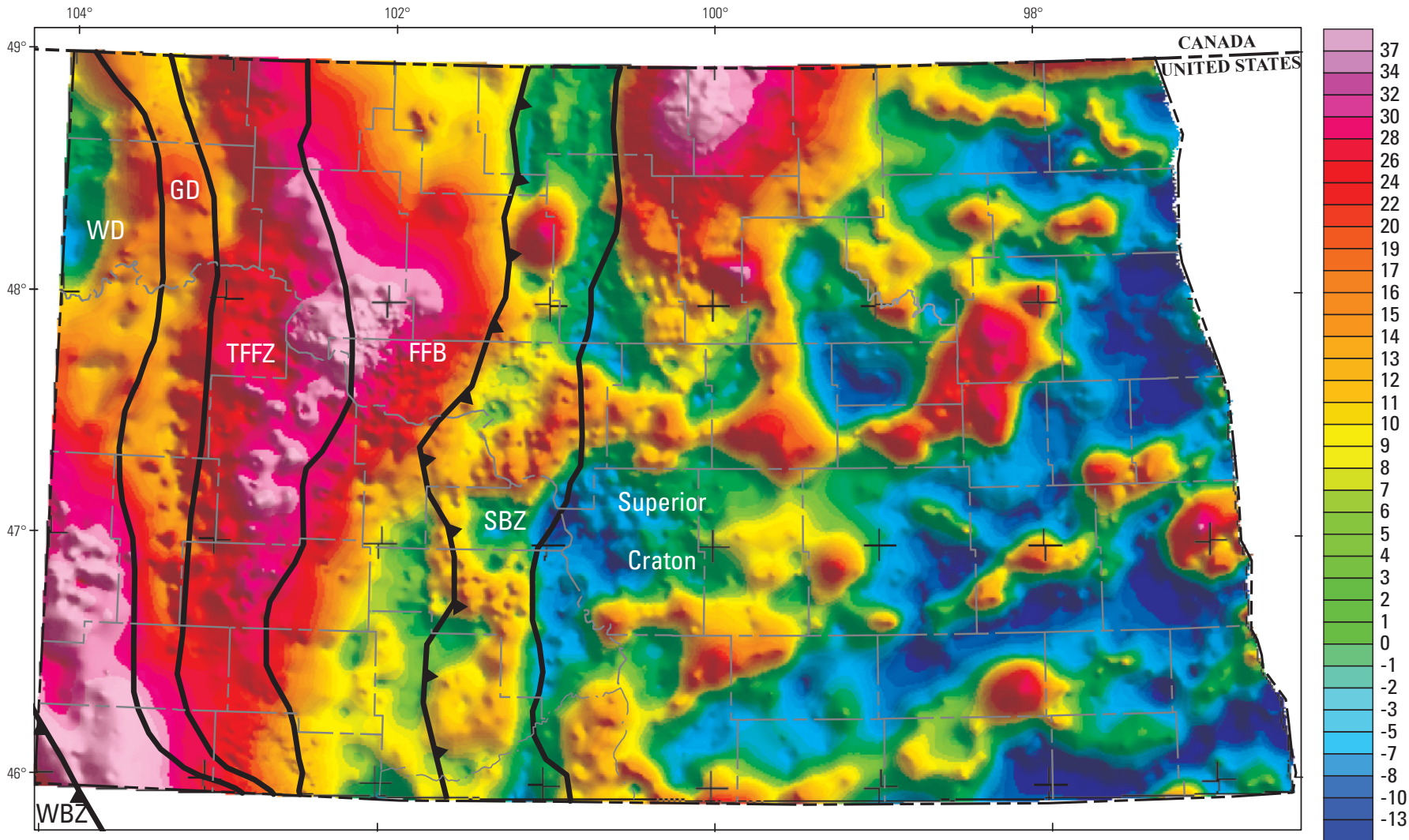

Isostatic gravity mapping modified from Sweeney and Hill, 2003; https://pubs.usgs.gov/of/2003/ofr-03-249/

NAD 1983 State Plane North Dakota South FIPS 3302 Feet,

Central meridian, $100^{\circ} \mathrm{W}$., latitude of origin, $45.7^{\circ} \mathrm{N}$.

North American Datum of 1983

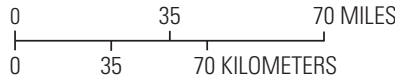

EXPLANATION

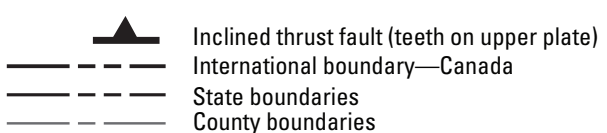

County boundaries

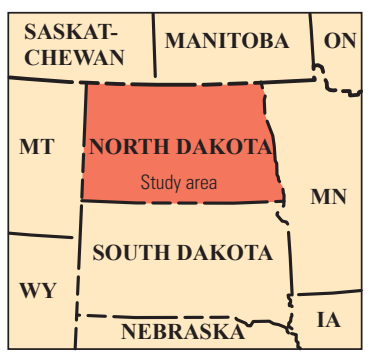

Figure 10. Isostatic-gravity map of North Dakota (from Sweeney and Hill, 2003). Precambrian basement terranes from Bader (2019). mGal, milligals.

by variably magnetic granitic rocks. The metasedimentary and metavolcanic rocks alternate in northeast-southwesttrending belts in the basement rocks of eastern North Dakota: metabasaltic rocks dominate in the southeast quarter, and metasedimentary rocks dominate in the northeast quarter. Most rocks in the Superior province are Archean (older than 2,500 Ma), although the presence of banded-iron formation suggests that some strata could be as young as Paleoproterozoic (2,500-1,800 Ma). The western margin of the Superior craton (Superior boundary zone) was structurally mixed with Paleoproterozoic rocks along an east-dipping zone in the crust at about 1,800 Ma (Klasner and King, 1986), producing an electrically conductive (Bedrosian and Finn, 2019) and weakly magnetic zone that has moderate density.

The Trans-Hudson orogen, which underlies most of western North Dakota, consists of rocks that are younger (early Proterozoic, 2,000-1,700 Ma) than those of the Superior craton. The Trans-Hudson orogen rocks consist of distinct north-south-trending geophysical subunits (figs. 9, 10) that have contrasting magnetic and gravity expressions. These subunits can be tracked northward in southern Canada, into geological domains exposed on the Canadian shield (White and others, 2005). In Canada, the easternmost subunit (the Flin Flon belt, consisting of early Proterozoic oceanic volcanic-arc lavas and underlying plutonic rocks) can be traced southward into North Dakota as a belt of irregular magnetic highs (fig. 9) and moderate to high densities (fig. 10). The three subunits (Tabbernor Fold and Fault Zone, Glennie domain, and Williston domain) to the west consist of mixed metasedimentary and metamorphosed oceanic crustal rocks, which are remnants of oceanic basins that separated the older, continental Superior and Wyoming cratons. Thermochronological studies (summarized in Schneider and others, 2007) indicate that rocks of the Trans-Hudson orogen 
were metamorphosed in the middle crust at about $1,800 \mathrm{Ma}$ and then were exposed gradually by uplift and erosion before deposition of the Athabasca quartzite at about 1,650 Ma.

The Wyoming craton broadly consists of Archean granitic and metabasaltic rocks; only the Wyoming boundary zone (figs. 9, 10) clips the southwest corner of North Dakota. These granitic and metabasaltic rocks extend northward from the Black Hills in South Dakota, where Archean granites and metasedimentary rocks are exposed. Rocks of the Wyoming boundary zone have a notable structural and thermo-tectonic overprint (dated as 1,780-1,690 Ma; Dahl and others, 2005; Schneider and others, 2007) that represents the collision of the Wyoming craton with the rocks of the Trans-Hudson orogen. A prominent electrically conductive zone (the North American Central Plains anomaly) cuts deeply through the crust (with a westward dip) along the Wyoming boundary zone (Bedrosian and Finn, 2019).

Rocks of the three basement blocks were brought together by subduction of the oceanic crust between them, resulting in crustal collisions between 1,800 and 1,700 Ma. Uplift of the amalgamated crust continued for hundreds of millions of years after collision, during which erosion removed 10 to 20 kilometers $(\mathrm{km})$ of rocks above the mid-crustal rocks of the Superior craton and Trans-Hudson orogen. Since about $1,600 \mathrm{Ma}$, the crust that is now North Dakota is not known to have been subjected to intrusion by molten magmatic rocks nor to metamorphism at elevated temperatures and pressures. The lack of these processes means rocks younger than the basement rocks have not been subjected to circulating hightemperature magmatic or metamorphic waters that are the typical carriers of elements found in metallic mineral deposits (see "Mineral Inventory of North Dakota" section).

\section{Stratified Rocks of the Williston Basin}

The Precambrian basement rocks in the central part of western North Dakota are overlain by more than $4877 \mathrm{~m}$ $(16,000 \mathrm{ft})$ of stratified sedimentary rocks (Kent and Christopher, 1994) at the thickest part of the Williston Basin (fig. 8). The sedimentation history has been generally described as marine carbonate deposition in the Paleozoic Era (540$250 \mathrm{Ma}$ ) and marine and nonmarine sand and mud deposition in the Mesozoic and Cenozoic Eras (250 Ma to the present) (Anna and others, 2013). A detailed stratigraphic column for North Dakota (which gives rock formation names, lithologic descriptions, and unit ages) from Murphy and others (2009) is adapted here in figure 7. A generalized discussion of the Phanerozoic (540-0 Ma) geologic history of North Dakota and its stratigraphy is given below.

Sloss (1963) separated deposition of the Phanerozoic stratigraphic section of the cratonic interior of North America into six named depositional sequences, which are separated by unconformities that mark periods of erosion and nondeposition. The lowest sequence, the Sauk sequence (cratonic sequence CS-1), began with marine flooding of the deeply eroded Precambrian mountain belt roots, depositing sandy to muddy, upper Cambrian to lower Ordovician strata (510-490 Ma) onto the much older crystalline, metamorphic and plutonic basement rocks. Rocks of the CS-1 sequence are about $300 \mathrm{~m}(1,000 \mathrm{ft})$ thick along the western North Dakota border and progressively thin eastward to an erosional wedge-out west of the Red River of the North Valley. The marine waters receded and left the land surface above sea level for about 30 m.y., resulting in the removal of the CS-1 sequence rocks from under the Red River of the North Valley and leaving an erosional surface across the top of the entire CS-1 sequence rocks. Rocks of the CS-1 sequence have some potential for hosting helium deposits in North Dakota (see "Helium" section)

The next sequence, the Tippecanoe sequence (CS-2; 460-430 Ma), began with the readvance of marine waters across the entire State and the deposition of a basal, fairly pure quartz, beach sandstone (the Black Island Formation), overlain by fine-grained, shaly strata offshore. Several cycles of shallow marine and tidal deposition followed, leaving a mixture of carbonate (limestone) and evaporitic rocks (anhydrite [calcium sulfate], salt deposits). This sequence marks the beginning of increased subsidence of the circular Williston Basin depocenter (thickest area of basin strata) in central-western North Dakota, which contains more than $762 \mathrm{~m}(2,500 \mathrm{ft})$ of CS-2 sequence rocks that thin in all directions, pinching out along the eastern North Dakota border. Marine waters receded to end the depositional sequence, and erosion of the newly exposed land surface continued for about 20 million yr.

Next is the Kaskaskia sequence (CS-3; 410-325 Ma), which began when marine waters again advanced over the State, depositing mostly limestones, with two notable exceptions, the Prairie Formation and the Bakken Formation. Repeated cycles of limestone and evaporite deposition (the Prairie Formation) occurred in the early part of the CS-3 sequence, depositing more than $152 \mathrm{~m}(500 \mathrm{ft})$ of evaporitic anhydrite, halite, and potash salts that have generated some economic interest (see "Potash" section). The Bakken Formation of black, organic-rich, marine shale, which is the source of most of the oil wealth of North Dakota, constitutes the middle of the CS-3 sequence. Thick deposits of Mississippian carbonate rocks (360-325 Ma) make up most of the upper half of the CS-3 sequence. Rocks of the CS-3 sequence are more than $1219 \mathrm{~m}(4,000 \mathrm{ft})$ thick in the Williston Basin depocenter in northwestern North Dakota and thin in all directions before pinching out eastward, just west of the Red River of the North Valley. The CS-3 sequence ended when the seas receded for a few million years, producing another erosional surface.

Next is the Absaroka sequence (CS-4; 320-210 Ma), during which predominantly shallow-marine to nonmarine, shaly strata, with some sand and carbonate-rock intervals, were deposited in its lower half, followed by sporadic intervals of salt deposition, particularly in the deeper parts of the Williston Basin. Rocks of the CS-4 sequence are more than $457 \mathrm{~m}(1,500 \mathrm{ft})$ thick in the Williston Basin depocenter, thinning away from it and pinching out across a north-southtrending line near the center of the State. A 30-m.y. erosional 
period followed the CS-4 sequence, apparently removing strata that once covered the east half of the State.

The next sequence, the Zuni sequence (CS-5; 180$50 \mathrm{Ma}$ ), began with resumed subsidence of the Williston Basin in the Early Jurassic, with deposition of evaporitic anhydrite and halite in the basin depocenter and shale and carbonate around the basin margins. By $150 \mathrm{Ma}$, alluvium from the rising Rocky Mountains to the west advanced across North Dakota, marking the end of increased subsidence around a defined Williston Basin depocenter. By $130 \mathrm{Ma}$, a major north-south-trending marine trough developed from Alberta to New Mexico, including North Dakota. Beach sands deposited in this environment have potential to host heavy-mineral paleoplacer deposits (see "Heavy-Mineral Paleoplacers" section). About $70 \mathrm{Ma}$, alluvium derived from the Rocky Mountains mostly pushed the marine waters out of the region, building a swampy lowland inhabited by a profusion of dinosaurian and, later, mammalian fauna. Scattered beds of volcanic ash blown in from eruptions in the Rocky Mountains (some now altered to bentonitic clay; see "Bentonite" section) are found intermittently throughout the section. Lignitic coals in this sequence host concentrations of uranium and other elements, including rare earth elements and germanium (see sections "Uranium and Associated Elements" and "Rare Earth Elements (REE) and Germanium in Coal or Coal Fly Ash"). Some nonmarine claystone in this sequence has potential deposits of ceramic-grade kaolinite (see "Ceramic-Grade Kaolinite" section). Strata of the CS-5 sequence are about $1524 \mathrm{~m}(5,000 \mathrm{ft})$ thick along the west edge of the State and thin out completely near the Red River of the North on the eastern State border.

The Tejas sequence (CS-6; 40-0 Ma) followed about 10 m.y. of erosion. Rocks of the CS-6 sequence consist of brightly colored nonmarine claystone (some of which is

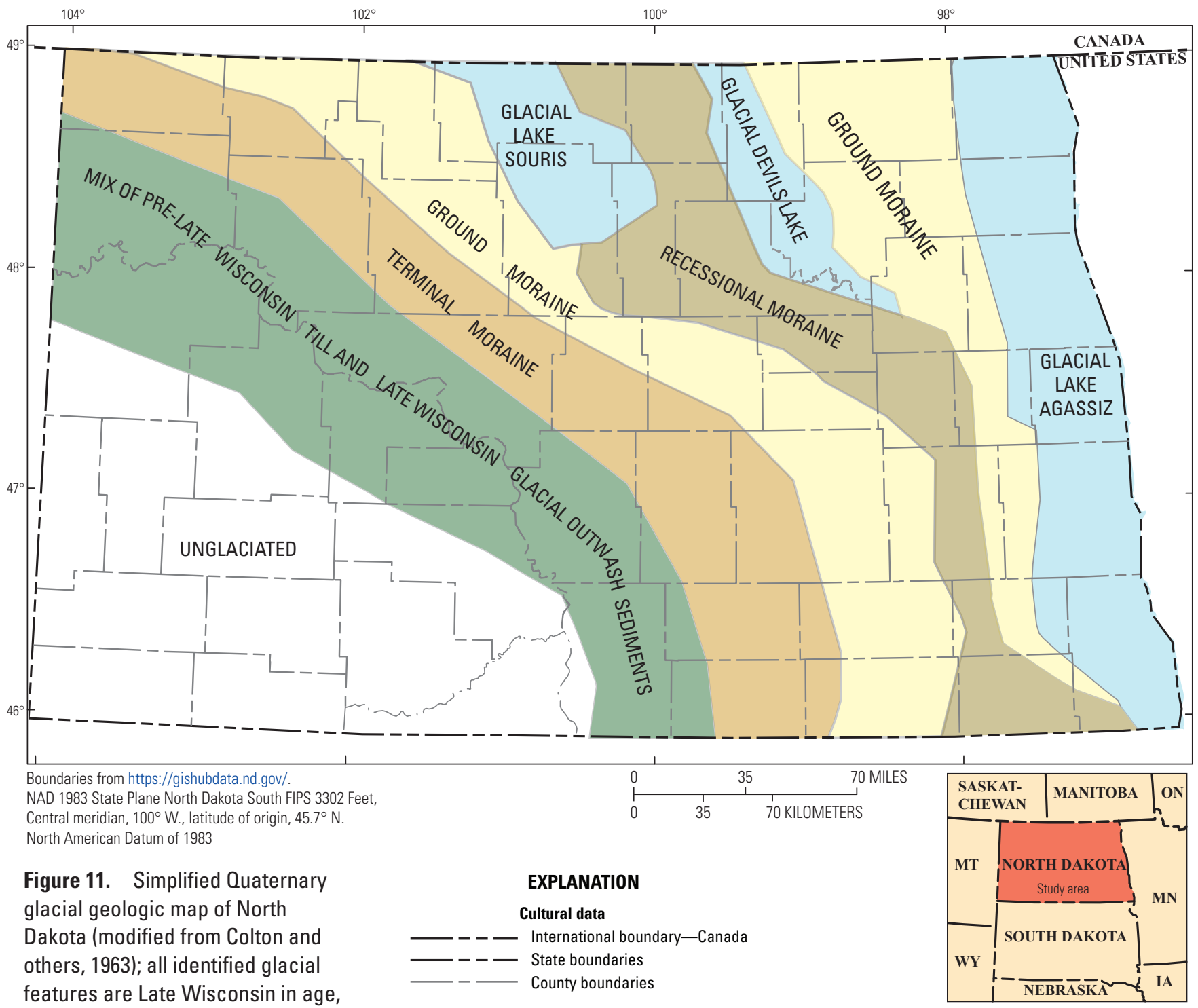

except where noted. 
kaolinitic) and scattered fluvial sandstones and conglomeratic strata. Widespread erosion after about $10 \mathrm{Ma}$ has removed much of the rocks of this sequence, so the original extent of the sequence is uncertain. Starting about $3 \mathrm{Ma}$, a succession of continental ice sheets formed in Canada and advanced across northern and into southeastern North Dakota, retreating for relatively short periods (10-20 thousand years [k.y.]), before repeatedly advancing across the State. Glacial ice last left the State about 12,000 yr ago. Humans colonized the State soon afterward in their migration into most areas of North and South America. Potentially economic occurrences of windblown sand, sodium sulfate, and manganese have been deposited in the last 12,000 yr (see sections "Natural Sand Proppant," "Manganese," and "Sodium Sulfate").

\section{Ice Age Glacial Deposits of North Dakota}

Glacial deposits cover about 80 percent of North Dakota (fig. 4), with older bedrock (mostly CS-5 sequence) exposed mostly southwest of the Missouri River in the southwestern part of the State and in a few river canyons in the northern and eastern parts of the State (Colton, 1963). The undulating northwest-trending upland ("Missouri Coteau" in fig. 2) between the Missouri escarpment and the Missouri River marks the position of the terminal moraine (fig. 11) of the continental glacier for several of the glacial periods, including the final (Late Wisconsin) glacial period. Along its southwestern flank ("Coteau Slope" in fig. 2), deposits of earlier (pre-Late Wisconsin) glacial moraines are mixed with deposits from streams that drained southwestward from the Late Wisconsin glacial terminus (fig. 11). Originally northward-flowing streams such as the Missouri and Little Missouri Rivers were blocked by the glacial advances, forming lakes flanking the glacial front. Sands and gravels from meltwater streams that drained off the front of the continental glacier filled dammed stream valleys with thick gravels, building and cutting southward-flowing meltwater drainages. Eventually these drainages integrated into the southeastward flow of the reestablished Missouri River, parallel to the terminal moraine of the Missouri Coteau. The complex history of glacial advances and retreats led to a complex drainage derangement history along the southwest flank of the Missouri Coteau.

East of the Missouri Escarpment, the much more subdued topography of the Central Lowlands reflects its extensive planation by repeated glacial advances and ground-moraine deposition over that low-relief surface. A band of mildly elevated ridges, 50 to $75 \mathrm{~km}$ east of the escarpment and roughly parallel to it, consists of mounded till of recessional moraines (fig. 11) formed during temporary advances during the final retreat of the Last Glacial Maximum (Bluemle, 1988). By inference, deposition of the ground moraine west of the recessional moraine should have ended while the ground moraine to the east continued to be deposited. As the continental glacier continued to retreat, the last glacial fingers into North Dakota occupied depressions in the ground moraine basins. As they retreated still farther, these late troughs became glacial lakes, blocked by recessional moraines and fed by the retreating glacial ice melt (fig. 11; Fullerton, 1995). The southern arm of Glacial Lake Agassiz occupied the Red River of the North Valley, with the lake extending far north into Canada (fig. 2). Narrower arms extended southward from Canada into the Souris Lake Plain and Devils Lake Basin. As Glacial Lake Agassiz shrank, sandy shoreline deposits built eastward over finer deep-water lake muds along its west flank. The Souris Lake basin is filled with similar early muds overlapped by sandy-shoreline beach deposits.

Since the retreat of the glacial ice and drainage of the recessional glacial lakes, new stream drainages were established in areas formerly occupied by ice and water. The Red River of the North established its northward-flowing course as the waters of Glacial Lake Agassiz retreated. Likewise, the lower Souris River drained northward as Glacial Lake Souris retreated, and it captured the southeastward-flowing upper Souris River. The hummocky morainal deposits of the Missouri Coteau remained poorly drained, hosting many small lakes and ponds that had no outlet. Summer evaporation on these lakes led to their saline character, and many host potentially economic deposits of evaporitic sodium sulfate (see "Sodium Sulfate" section). Extensive areas of sandy eolian dunes developed over the last 10,000 years by reworking of the sandy lake-shoreline deposits of Glacial Lakes Agassiz and Souris. These sands have some potential as proppant material for hydraulically fractured petroleum wells (see "Natural Sand Proppant" section).

\section{Mineral Inventory of North Dakota}

The mineral resource inventory of North Dakota begins with information on Federal mineral authorizations taken from the LR2000 database of the BLM (fig. 12). Those sites are combined with a compilation of all known surface mineral commodity occurrences and prospects from three other publicly available databases (figs. 13, 14). The mineral inventory of North Dakota that follows is organized by commodity classification as locatable, leasable or salable.

Because of the limited commodity occurrences in these databases beyond sand and gravel and aggregate, we stepped back to consider which elements (or commodities) of interest might be present in North Dakota at economic depths. We first considered metallic elements and minerals. Most mineral deposits form from one of the following restricted set of processes: (1) magmatic crystallization, formed within an igneous rock body during the intrusion, cooling and crystallization of magma; (2) magmatic hydrothermal, formed by the interaction of rock with circulating groundwater heated by a magmatic heat source; (3) metamorphic hydrothermal, formed by the interaction of rock with ascending hot water with a metamorphic heat source; (4) nonmagmatic basinal circulation, formed by interaction of heated groundwater (commonly with briny composition) and a sedimentary 


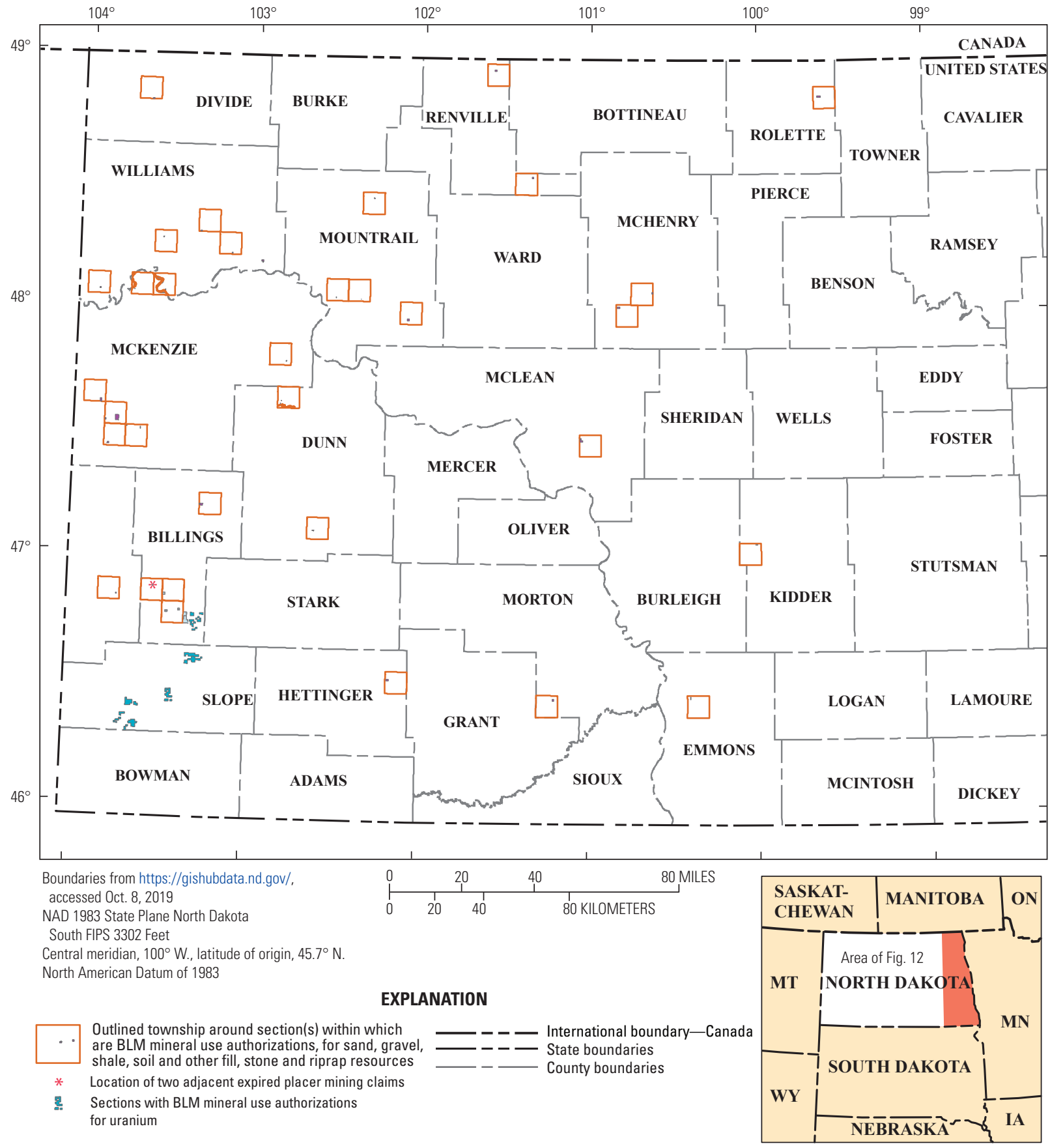

Figure 12. Map showing Bureau of Land Management mineral-use authorizations for nonenergy solid minerals in western part of North Dakota, shown by section (data from BLM LR2000 database; see table 1.1); also shown are only recorded mining claims (two expired placer claims) in western North Dakota (data from BLM LR2000 online database; see table 3). 


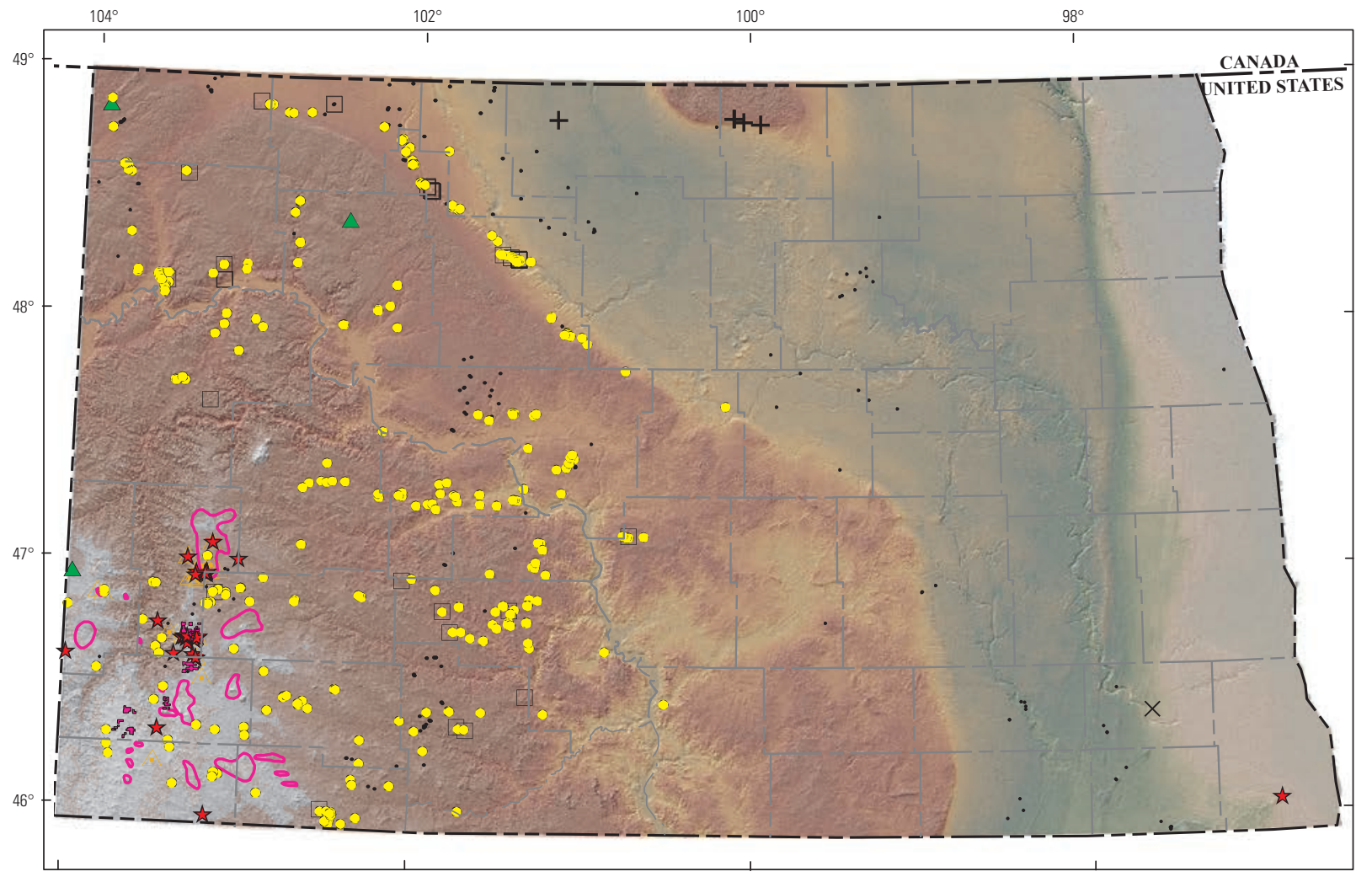

Base data, Global Digital Elevation Model (ETOPO2), from National Geophysical Data Center ETOPO2 Global 2' Elevations dataset from September 2001 Boundaries from https://gishubdata.nd gov/

NAD 1983 State Plane North Dakota South FIPS 3302 Feet

Central meridian, $100^{\circ} \mathrm{W}$., latitude of origin, $45.7^{\circ} \mathrm{N}$

North American Datum of 1983

\section{EXPLANATION}
- Coal, lignite
$\triangle$ Sodium sulfate
+ Manganese
$X$ Iron

NDAML, USMIN, and MRDS Data

th Uranium (easternmost location: Iongitude error?)

$\square$ Underground mine, unknown commodity

- Surface strip mine, prospect or open pit unknown commodity

\section{LR2000 Data}

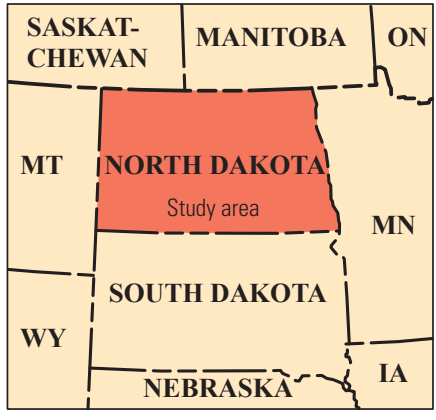

- Uranium prospect permit section Uranium Historical Data [From Murphy, 2007]

Uraniferous deposit

Abandoned uranium mine; 1960s activity

International boundary-Canada

State boundaries

County boundaries

Figure 13. Shaded-relief physiographic map of North Dakota, showing mines, prospects, and occurrences of coal, lignite, uranium, and other mineral commodities (data extracted from LR2000, MRDS, USMIN, and NDAML databases), as well as outlines of uranium deposits (from Murphy, 2007). Anomalous uranium locality in southeast corner of State may be result of error in longitude value. 


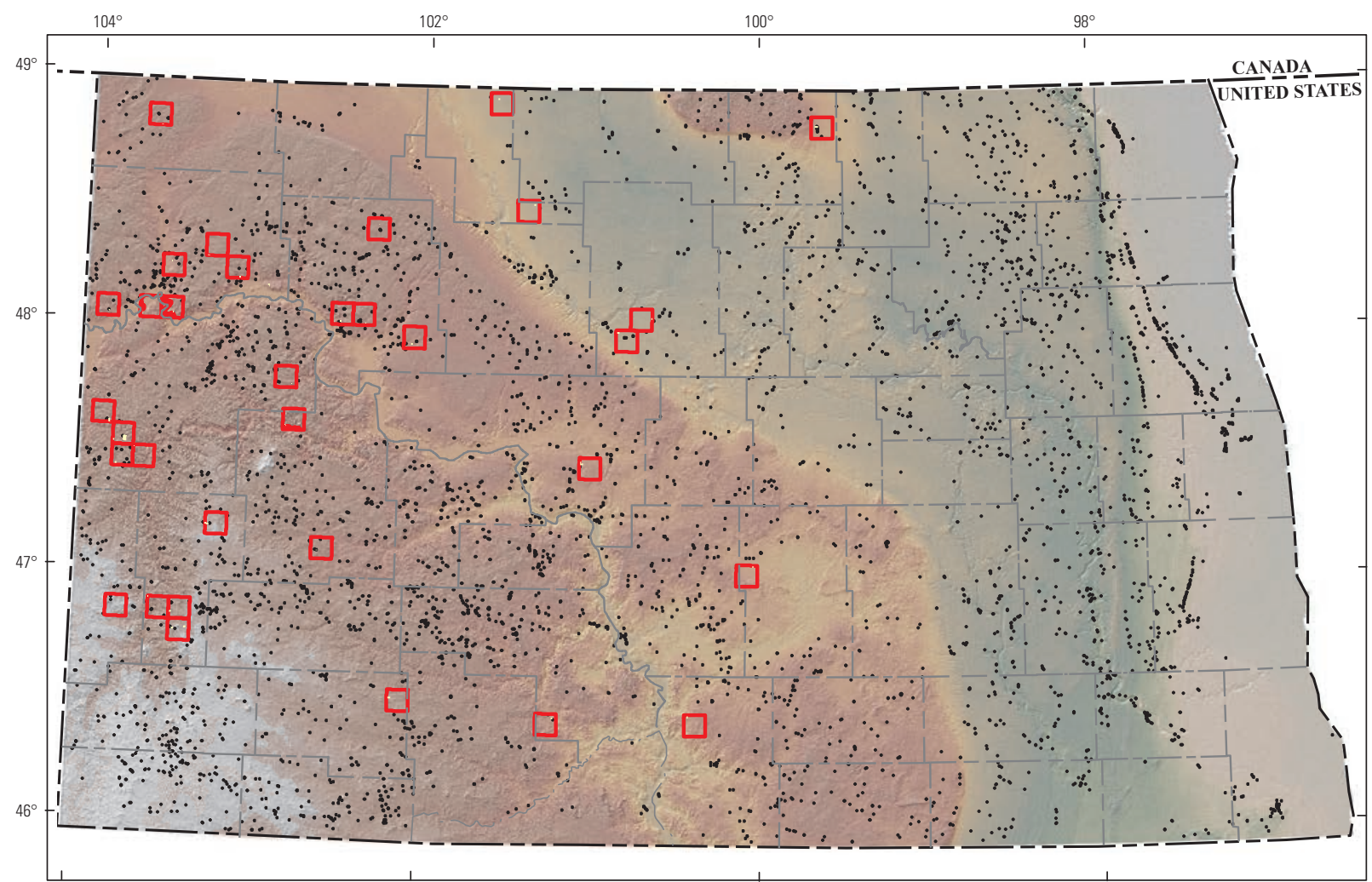

National Geophysical Data Center ETOP02 Global 2 Elevations dataset from September 2001

Boundaries from https://gishubdata.nd.gov/

NAD 1983 State Plane North Dakota South FIPS 3302 Feet

Central meridian, $100^{\circ} \mathrm{W}$., latitude of origin, $45.7^{\circ} \mathrm{N}$.

North American Datum of 1983

\section{EXPLANATION}

Distribution of sand, gravel, shale, soil, stone, and riprap resources-BLM LR2000 data (201911)

Township within which occur BLM mineral use authorizatons for sand, gravel, shale, soil and other fill, stone and riprap resources

Distribution of sand, gravel, shale, soil, stone, and riprap resources-NDAML, USMIN, and MRDS Data

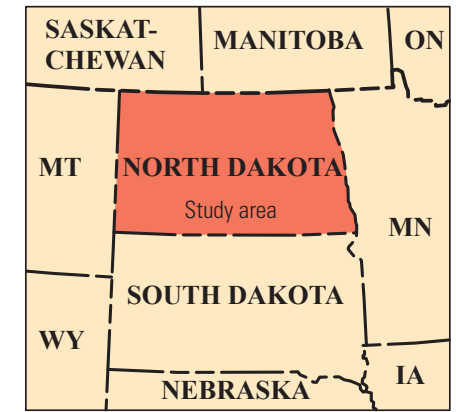

- $\quad$ point locations for sand- and gravel-related data in AML, USMIN, and MRDS databases

$\begin{array}{ll}--- & \text { International bound } \\ ---\square & \text { State boundaries } \\ -- & \text { County boundaries }\end{array}$

Figure 14. Shaded-relief physiographic map of North Dakota, showing sand and gravel, clay pits and stone quarries (active and abandoned) (data extracted from LR2000, MRDS, USMIN, and NDAML databases)

sequence; (5) sedimentary precipitation, formed by the precipitation or settling of minerals directly from water in oceans or lakes; (6) mechanical placers, formed by the physical concentration of heavy particles of rocks or minerals by the action of moving water; and (7) residual laterite, formed by concentration of resistant minerals during intense weathering of rocks under hot, humid conditions (Zientek and Orris, 2005). In table 1 we present the list of commodities considered for inventory in this report, followed by the principal and subsidiary deposit types in which they occur worldwide (from Schulz and others, 2017) and which of the seven environments of mineral deposit genesis can produce those deposit types, as well as the potential for that commodity in North Dakota.

Processes 1, 2, and 3 (magmatic-crystallization, magmatic-hydrothermal, and metamorphic-hydrothermal processes, detailed above) are not known to have occurred in North Dakota since the culmination of continental collision between the Precambrian basement blocks at about 1,700 Ma (discussed in "Precambrian History" section). Because these 
ore deposit types in North Dakota are likely restricted to moderately to deeply buried basement rocks, exploration for and exploitation of such potential resources would be difficult. Therefore, most commodities of interest associated with magmatic and (or) hydrothermal deposits in table 1 are too deeply buried for economic exploration or development. Historically, however, there has been some exploration of basement rocks using geophysical techniques in eastern North Dakota, where basement rocks are relatively shallow (see "Potential Ore Deposits in the Crystalline Basement Rocks, Easternmost North Dakota" section).

Within the thick stratified sedimentary sequence that overlies the crystalline basement rocks (Williston Basin and correlative strata), other types of mineralizationnonmagmatic basinal-circulation, sedimentary-precipitation, mechanical-placers, or residual-laterite processes (processes 4 through 7, detailed above) - may have occurred. Because only the very highest parts of the Phanerozoic stratigraphic section crop out in North Dakota, potential deposits of these types would be mostly associated with deeply buried strata, rendering them difficult to discover and probably uneconomic to exploit (table 1). However, we have identified several examples of such commodity occurrences that possibly could be economically exploitable in North Dakota (see sections "Potash," "Helium," and "Sodium Sulfate").

The inventory concludes with a brief discussion of salable commodities (sand and gravel, crushed stone, aggregate, clay) in the section "Salable Commodities."

\section{Known Mineral Occurrences}

We accessed four databases to identify known mineral occurrences in North Dakota (appendix 1). A database of 34 North Dakota sites was extracted from the BLM Legacy Rehost System database (LR2000) and forwarded to the USGS on October 9, 2019. The site locations are shown in figure 12, and the data are tabulated in table 1.1. LR2000 provides reports on BLM land and mineral use authorizations for oil, gas, and geothermal leasing; rights-of-way; coal and other mineral development; and land and mineral title, mining claims, withdrawals, and classifications on Federal lands or on Federal mineral estate (fig. 12). Each entry gives information on mineral use authorization, commodity, and area for each authorization issued by the BLM on Federal actions affecting public lands of the United States. In North Dakota these sites include those covered by exploration permits for uranium (9 sites) and those that have authorizations for quarrying for sand and gravel, as well as stone for riprap ( 25 sites). From the online LR2000 site (https://reports.blm.gov/report/lr2000/24/ Pub-MC-Geo-Report) for mining claims in North Dakota, two placer claims were reported (table 3, located after the "References Cited"). These locations are shown on figure 12.

The USGS Mineral Resources Program maintains the Mineral Resource Data System (MRDS), a mineral occurrence database that describes metallic and nonmetallic mineral resources throughout the world (McFaul and others, 2000). The data for North Dakota (table 1.2) were downloaded September 23, 2019, from the USGS website portal (https:// mrdata.usgs.gov/mrds/). Each entry gives the deposit or prospect name, location, commodity, deposit description, geologic characteristics, production, reserves, resources, and references. The present MRDS database subsumed the Mineral Availability System/Mineral Industry Location System database (MAS/MILS), which was previously maintained by the Bureau of Mines until its disbandment in 1996. As of 2011, USGS has ceased systematic updates to MRDS. A total of 323 entries in North Dakota were extracted from the MRDS database. The USGS is working to create a new database, focused primarily on the conterminous United States.

Another USGS effort has been to digitize mining-related features from historical USGS topographic maps in the conterminous United States (U.S. Mineral Deposit Database [USMIN]; https://www.usgs.gov/centers/gggsc/science/usminmineral-deposit-database?qt-science_center_objects $=0 \# q t-$ science_center_objects). These features include prospect pits, mine shafts and adits, quarries, open-pit mines, tailings piles and ponds, and gravel and borrow pits. The data for North Dakota (table 1.3) were downloaded November 13, 2019, from the USGS website portal (https://mrdata.usgs. gov/usmin/). A total of 4,440 sites from North Dakota were extracted from the site. Limited information is available from the database, including feature type (adit, gravel pit, uranium mine, and so on) and the feature name, if available.

North Dakota maintains a database of abandoned mine sites (NDAML) in the State (accessed October 16, 2019 from https://gishubdata.nd.gov/dataset/abandoned-mines). Limited data beyond site location are available in the database, including mine name and mine type; it is sometimes possible to discern if the mine was for coal, lignite or uranium from information listed in the other fields. A total of 1,739 entries for North Dakota were pulled from the database (table 1.4).

A total of 6,625 database entries are found in these four databases. From this combined total, commodities listed include (the number of entries is given in parentheses) uranium (53), coal/lignite $(1,238)$, manganese (4), sodium (3), and iron (1); these are shown in figure 13. Most of the other 5,320 entries are for construction aggregate, including sand and gravel, stone, clay, shale, scoria, and clinker (fig. 14). Although coal/lignite and uranium are not part of the mineral commodities inventoried for this report, we do include a short section ("Uranium and Associated Elements") on uranium and associated elements, as some of the potentially associated elements - for example, vanadium, molybdenum, germanium, arsenic, selenium, and rhenium - are considered Critical Minerals. Manganese and sodium sulfate prospects are considered in their respective sections ("Manganese" and "Sodium Sulfate"), and construction aggregate is briefly considered in the section "Salable Commodities." 


\section{Locatable Commodities}

Locatable minerals are minerals for which the right to explore or develop the mineral resource on Federal lands is established by the location (or staking) of lode or placer mining claims and authorized under the General Mining Law (May of 1872). Locatable minerals include metallic minerals (for example, gold, silver, platinum, palladium, copper, lead, zinc, molybdenum, uranium, tungsten, chrome, and others) and nonmetallic minerals (for example, fluorspar, asbestos, talc, mica, limestone, and others).

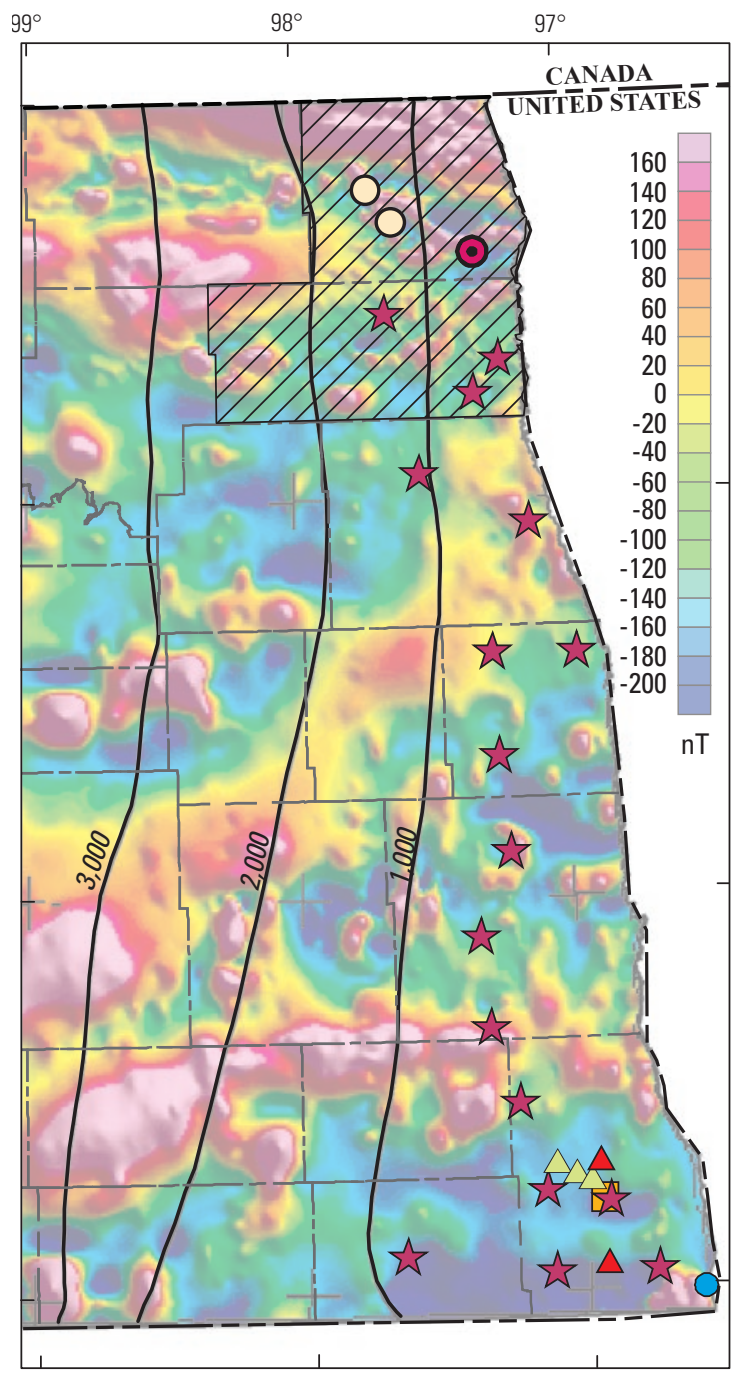

Boundaries from https://gishubdata.nd.gov/, accessed Oct.8, 2019 NAD 1983 State Plane North Dakota South FIPS 3302 Feet Central meridian, $100^{\circ} \mathrm{W}$., latitude of origin, $45.7^{\circ} \mathrm{N}$. North American Datum of 1983

\section{Potential Ore Deposits in the Crystalline Basement Rocks, Easternmost North Dakota}

Historically, some exploration in the basement rocks of North Dakota occurred near the eastern State border, where basement rock is less than $305 \mathrm{~m}(1,000 \mathrm{ft})$ deep (Nesheim, 2014). Figure 15 shows the locations of known exploratory drill holes to Precambrian basement in easternmost North Dakota (modified from Nesheim, 2014). In 1964, two companies independently targeted test drill holes at magnetic highs near the southeast and northeast corners of the State

Figure 15. Magnetic-anomaly map showing exploratory test wells into Precambrian basement rocks in eastern North Dakota (from Nesheim, 2014), overlain on aeromagnetic map (from fig. 9) and depth to Precambrian basement contours (from fig. 8). 
(in Richland and Pembina Counties, respectively). The northeastern target (tested by Amerada-Hess Petroleum Corporation) was apparently iron ore, but only subeconomic iron-rich rocks at depths below $305 \mathrm{~m}(1,000 \mathrm{ft})$ were found. Large surface reserves of iron ore in neighboring Minnesota made continued exploration for deep iron ore in North Dakota unattractive. The southeastern exploration holes (drilled by New Jersey Zinc Company) targeted lead-zinc deposits, but only uneconomic iron-rich deposits (36-38 percent iron) in basement rocks below $37 \mathrm{~m}$ (120 ft) of glacial drift were found. Neither company continued exploration in the State.

During the uranium boom in the late 1970s, several companies tested the basement rocks in easternmost North Dakota for uranium deposits of uncertain type in either the Phanerozoic sedimentary sequence or in the Precambrian basement rocks (Nesheim, 2014). The first of these in 1977 resulted in 32 drill holes (known as the Red River Valley Drilling project) by the Bendix Field Engineering Company in Sargent, Richland, Cass, Trail, Grand Forks, and Walsh Counties (fig. 14); 26 of the drill holes penetrated basement rocks. That same year, two other operators (John Simmons of Bismarck, North Dakota, and Rocky Mountain Energy Company of Denver, Colorado) planned to drill more than 50 exploratory wells in Richland County in southeastern North Dakota, also in search of uranium deposits in the Precambrian basement rocks. Ultimately only two drill holes, each less than $152 \mathrm{~m}(500 \mathrm{ft})$ deep, were completed with no reported discoveries before all additional drilling ceased. An additional 27 exploration holes were drilled for uranium by two other operators (David Fitch of Albuquerque, New Mexico, and Exxon Minerals Company) in Richland County between 1978 and 1981. No economic deposits of uranium were reported in these drill holes and both the drill holes and the exploration efforts were quickly abandoned.

\section{Potential Locatable Critical Mineral Occurrences in Phanerozoic Stratified Rocks}

Although there is some discussion in the published literature concerning potential Critical Mineral deposits in North Dakota, no locatable Critical Mineral occurrences have been reported in the State except for uranium deposits, which we discuss here with respect to their associated elements. We also discuss two other potential Critical Mineral deposits in North Dakota - rare earth elements (REE) in coal and lignite; and titanium, zirconium, and other elements in heavy-mineral placers in Cretaceous and Tertiary sandstones.

\section{Uranium and Associated Elements}

Although energy-related resources such as uranium mineral deposits are outside the scope of this report, the known uranium occurrences in North Dakota warrant a brief discussion because of Critical Elements that are known or suspected to occur in these deposits. Small uranium deposits are known from Tertiary strata in western North Dakota (fig. 13), and between 9 and 15 small mines operated between 1962 and 1967 (Murphy, 2007), which produced almost 272 tonnes (300 short tons) of $\mathrm{U}_{3} \mathrm{O}_{8}$. The deposits are typically hosted within Upper Cretaceous to Eocene (75-45 Ma) lignitic coal intervals (Denson and others, 1965). Uraniferous horizons average only about $0.61 \mathrm{~m}$ $(2 \mathrm{ft})$ in thickness and have uranium contents from 0.01 to 0.2 percent. The uranium is thought to have been leached from tuffaceous horizons in Oligocene and Miocene strata by downward-percolating, oxygenated surface waters and redeposited by reduction of uranium-bearing groundwater in carbonaceous horizons (low-grade lignitic coal) deeper in the section. Most known occurrences are in lignites within the Paleocene Sentinel Butte Formation, the stratigraphically highest, semicontinuous lignite interval. Other trace elements are known to be associated with the uranium deposits (for example, vanadium, molybdenum, germanium, arsenic, and selenium; Denson and others, 1965; Murphy, 2009a), and others might be suspected (for example, rhenium is usually associated with molybdenum) on the basis of associations in other uranium deposits. However, little information is available as to the grades or resources of these commodities in the known uranium deposits.

\section{Rare Earth Elements and Germanium in Coal or Coal Fly Ash}

Some attention internationally has been given to the potential of coal and coal fly ash as a resource for rare earth elements (REE) (Seredin and others, 2013; Franus and others, 2015; Sahoo and others, 2016) and for germanium (Stadnichenko and others, 1953). The NDGS has been investigating the REE potential of several outcropping lignites and carbonaceous mudstones in the Cretaceous and Tertiary sections of western North Dakota (Kruger, 2015, 2017; Kruger and others, 2017; Murphy and others, 2018; Murphy, 2019). Total REE contents in North Dakota lignitic coals (fig. 13) are roughly double the averages reported for coals in the United States and globally (Kruger and others, 2017). About 5 percent of about 300 samples have total REE concentrations greater than 300 parts per million (ppm), categorized as "high" by the U.S. Department of Energy (Kruger and others, 2017). Subsequent analysis of a few samples by Murphy and others (2018) resulted in even higher REE values (as much as $1,145 \mathrm{ppm}$ ).

Seredin and Finkelman (2008) reviewed the genetic types and geochemical processes that have formed "metalliferous" coals around the world. Some REE-bearing coals originate by deposition of felsic volcanic ash in marsh environments where coals accumulated. Similar to uranium, some REE can be extracted by downward-percolating meteoric waters from ashes in the overlying stratigraphic section and precipitated by reduction when REE-bearing meteoric waters penetrate coaly strata. Although the controls of REE concentration in lignite in North Dakota have not been analyzed in detail, some combination of these processes may be responsible for the high REE contents in some North Dakota lignites (Kruger and others, 2017). 
Anomalous germanium concentrations have been noted in North Dakota lignites (Murphy, 2009a). A subsidiary of an Australian mining company (Formation Resources Inc., a unit of PacMagMetals Ltd.) reported germanium dioxide contents as much as $271 \mathrm{ppm}$ during its drilling of a uraniferous lignite in southeastern Billings County. According to Hansen (1964), the germanium in North Dakota is not necessarily associated with the uranium at the top of the lignitic strata, but it may be associated with pyritic horizons near the base of the lignitic strata.

Although the currently known concentrations of REE and germanium in North Dakota coal samples are presently considered to be uneconomic, much uncertainty remains about the processing of these elements from coal or coal fly ash and its potential costs. Whether or not the recovery of REE and (or) germanium from coal or from coal ash can become economically viable in the future remains uncertain.

\section{Diamond-Bearing Kimberlite Pipes}

Diamonds are typically associated with a peculiar type of gaseous magmatic eruption vent known as a kimberlite pipe, although many kimberlites lack diamonds. Kimberlite magma originates at diamond-forming depths by small degrees of partial melting of mantle that has stabilized below old cratonic crust (Hunt and others, 2012). The gaseous magma blasts upward to the surface through cratonal crust that typically is $48 \mathrm{~km}$ (30 mi) thick. Kimberlites consist predominantly of minerals that are rich in iron and magnesium (olivine and pyroxene) and are susceptible to alteration by fluids in their upward passage, resulting in the formation of serpentine minerals and magnetite. Magnetic surveys can identify buried kimberlite pipes by their strongly magnetic character.

Exploration for diamond-bearing kimberlites has increasingly occurred across the North American craton since the 1990s (Nesheim, 2013). Kimberlites within the Superior craton seem to be more diamondiferous than kimberlites found globally (Nesheim, 2016). In the early 2000s, a large international mining company (Kennecott Exploration Company, a subsidiary of Rio Tinto) conducted an aeromagnetic survey over Pembina and Walsh Counties in northeastern North Dakota, apparently searching for the magnetic expression of kimberlite (Nesheim, 2013; fig. 15, this report). Because kimberlite bodies in the Superior craton and in adjacent cratons in Wyoming range from 1,200 to $50 \mathrm{Ma}$ (Nesheim, 2016), the top of any kimberlite pipe in North Dakota might be found anywhere between the metamorphic basement-rock surface (fig. 8) and the pre-Quaternary bedrock surface (fig. 5). A single Kennecott well drilled in Pembina County in 2010 (fig. 15) encountered magnetite-rich Proterozoic granitic gneiss below $244 \mathrm{~m}(800 \mathrm{ft})$ depths that was the probable source of the magnetic anomaly; no kimberlites (or diamonds) were found. However, the opening of several North American diamond mines and the continuing exploration for kimberlite-associated diamonds suggest that future exploration for diamonds may take place in North Dakota.

\section{Heavy-Mineral Paleoplacers}

Economic concentrations of certain major (titanium) and trace (REE, zirconium, thorium) elements in heavy-mineralenriched seams are known globally within marine sandstones deposited in nearshore coastal (beach) environments (Van Gosen and others, 2010). Cretaceous marine sandstones are exposed in southwestern and south-central North Dakota (fig. 4) and in some of the river canyons in the northern and eastern parts of the State. Unfortunately, no published information on heavy-mineral paleoplacers in these Cretaceous sandstones could be found. Some information exists on heavymineral populations in Cretaceous and Tertiary nonmarine sandstones in North Dakota (Denson and Chisholm, 1971; Farris, 1984; Roehler, 1989; Murphy and others, 1993; Webster and others, 2015). In all of these, titanium-, zirconium-, and rare earth element-bearing minerals are found in trace amounts (at most) and would not be considered prospective for further investigation as possible sources of those elements.

\section{Other Potential Near-Surface Locatable Commodities}

Several locatable, noncritical mineral commodities are known to be present at or near the surface in North Dakota and include the following: ceramic-grade kaolinite, proppant sand (used to prop open fractures generated during hydraulic fracturing in oil and gas wells), bentonite, and sodium sulfate (used in detergents and in wood-pulp processing). Although no mining claims are known to have been filed for these commodities, discussion of these commodities in the literature suggests the possibility of their future exploitation. The first three commodities have been discussed for their potential use in the burgeoning oil and gas fields of North Dakota.

\section{Ceramic-Grade Kaolinite}

Ceramic-grade, high-alumina kaolinite is typically one of the main ingredients in the preparation of spherical ceramic beads for use as proppants injected into fractures during hydraulic fracturing in support of oil and gas development (Murphy, 2012a). Two kaolinite-rich stratigraphic units are exposed at the surface in southwestern North Dakota (Murphy, 1995), the Bear Den Member of the Golden Valley Formation (Murphy, 2009b) and the Rhame bed of Wehrfritz (1978) in the Slope Formation (figs. 4, 7); both units are Paleocene in age. These dazzling, white, gold, and purple units consist of

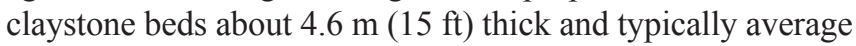
about 66 percent kaolinite, compared to 10 to 20 percent kaolinite in overlying and underlying units. The units are thought to have formed after two different periods of prolonged or intense weathering during the Paleocene (Murphy, 2013). A map showing the distribution of these two units and of samples analyzed for alumina content (correlative with kaolinite quality) is shown in figure 16 (from Murphy, 2012b). Although no mining claims or active kaolinite production is known in 


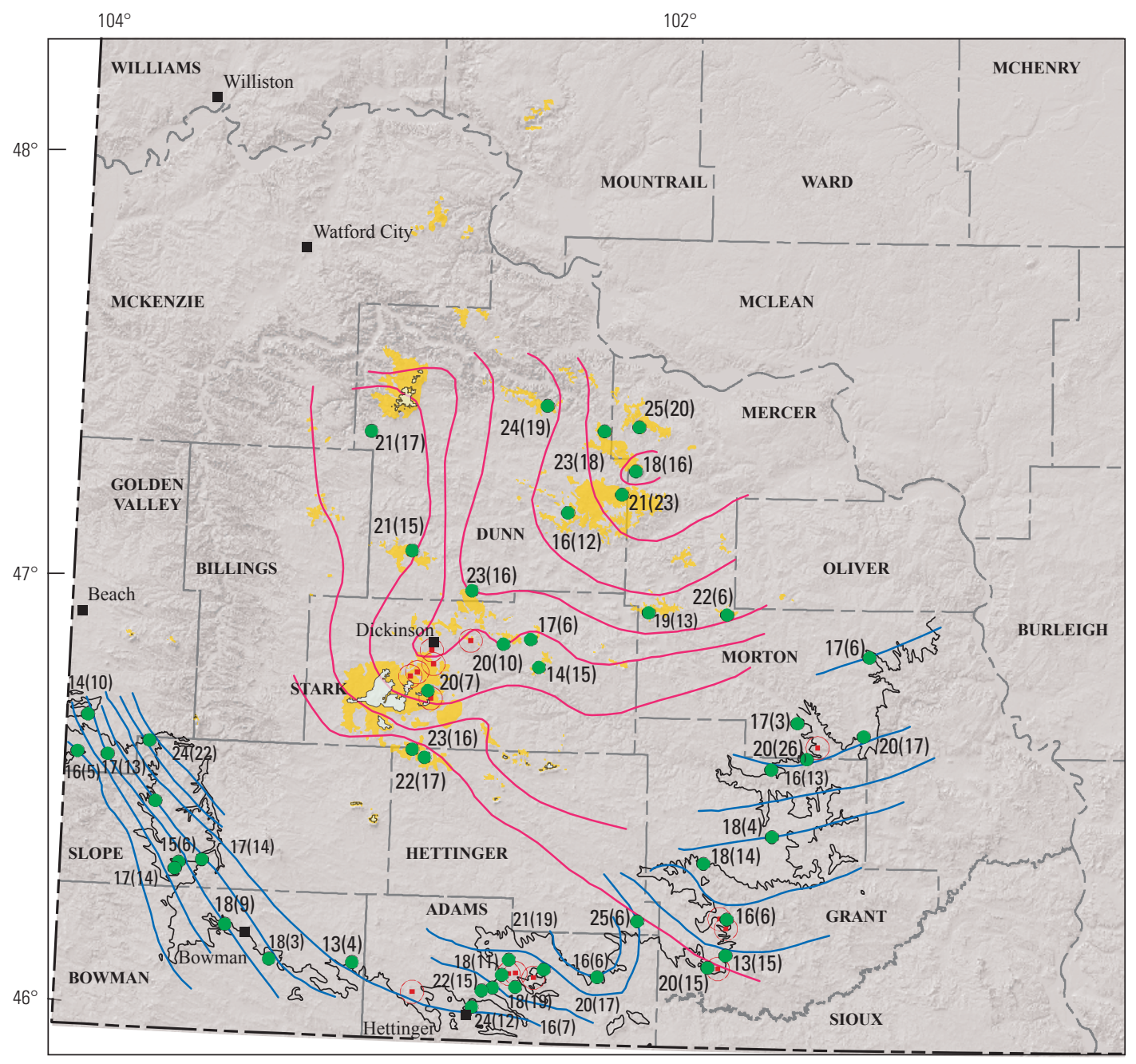

Boundaries from https://gishubdata.nd.gov/ NAD 1983 State Plane North Dakota South FIPS 3302 Feet, Central meridian, $100^{\circ} \mathrm{W}$., latitude of origin, $45.7^{\circ} \mathrm{N}$. North American Datum of 1983

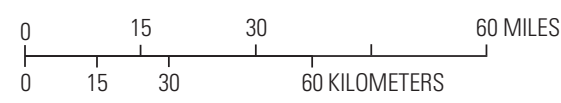

\section{EXPLANATION}

\section{Tertiary System}

White River and Arikaree Strata, undivided (Eocene to Miocene)

Bear Den Member of the Golden Valley Formation (Paleocene and Eocene)-Generally at surface along outer edges of formation

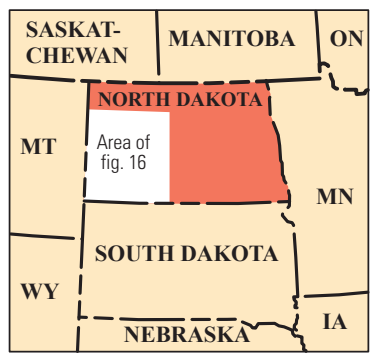

Rhame bed of the Slope Formation (Paleocene)-Top of the Rhame bed marks upper contact of formation

\section{Elevation contours (feet)}

Top of the Bear Den Member

- Top of the Rhame bed

State boundaries

County boundaries

- Outcrop control points for the Bear Den Member or the Rhame bed:

20 (10) Showing weighted alumina $\left(\mathrm{Al}_{2} \mathrm{O}_{3}\right)$ percentage and measured bed thickness in feet (in parentheses)

- Rock sample not analyzed City

Figure 16. Shaded-relief map showing distribution of two kaolinite-rich horizons in southwestern North Dakota, the Bear Den Member (at base of the Paleocene Golden Valley Formation, exposed at outer edge of map polygon) and the Rhame bed (at top of the stratigraphically lower Slope Formation). Stratigraphic classification from Clayton and others (1977), Murphy and others (2009). Map modified from Murphy (2012b). 


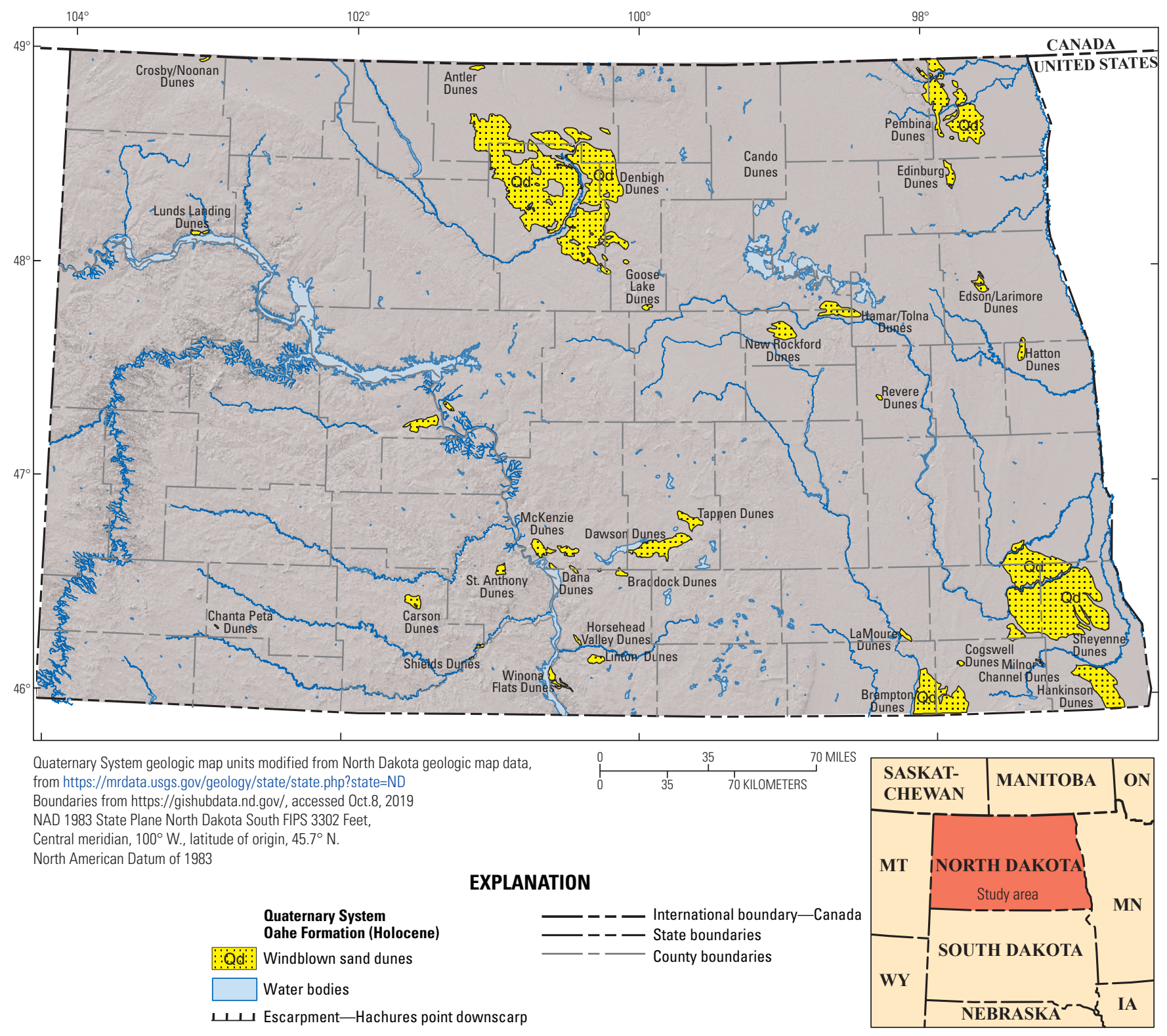

Figure 17. Shaded-relief map showing distribution of eolian dune sands in North Dakota, which are potential sources of oilfield hydraulic-fracture proppant (modified from Anderson, 2018b).

North Dakota, kaolinite appears to be a resource deserving further evaluation of its economic potential.

\section{Natural Sand Proppant}

Imported natural sand is also used as proppant injected into fractures during hydraulic fracturing in support of oil and gas development (Anderson, 2018a). Studies have evaluated sands from most of the Quaternary dune fields in North Dakota (figs. 4, 17; Anderson, 2018a, b, 2019a, b), in accordance with published and industry-approved recommendations and specifications. Characterization includes particle size distribution, grain sphericity and roundness, acid solubility, amount of silt and clay, crush resistance, mineralogy, and material densities (Anderson, 2018b). Initial characterization suggests that eolian sand resources in North Dakota are of a condition and quality that approach the extreme quality specifications of industry standards; however, they are of a lesser overall quality when directly compared with other extreme high-quality domestic sand sources currently used as proppant in the United States. Initial particle size and mineralogical characterization of selected Late Cretaceous and Paleocene bedrock sandstones suggest that they are of lower quality than the Quaternary dune sands (Anderson and others, 2019). A recent trend toward the relaxation of oil and gas industry requirements of extremequality natural sand proppants (which must be transported 


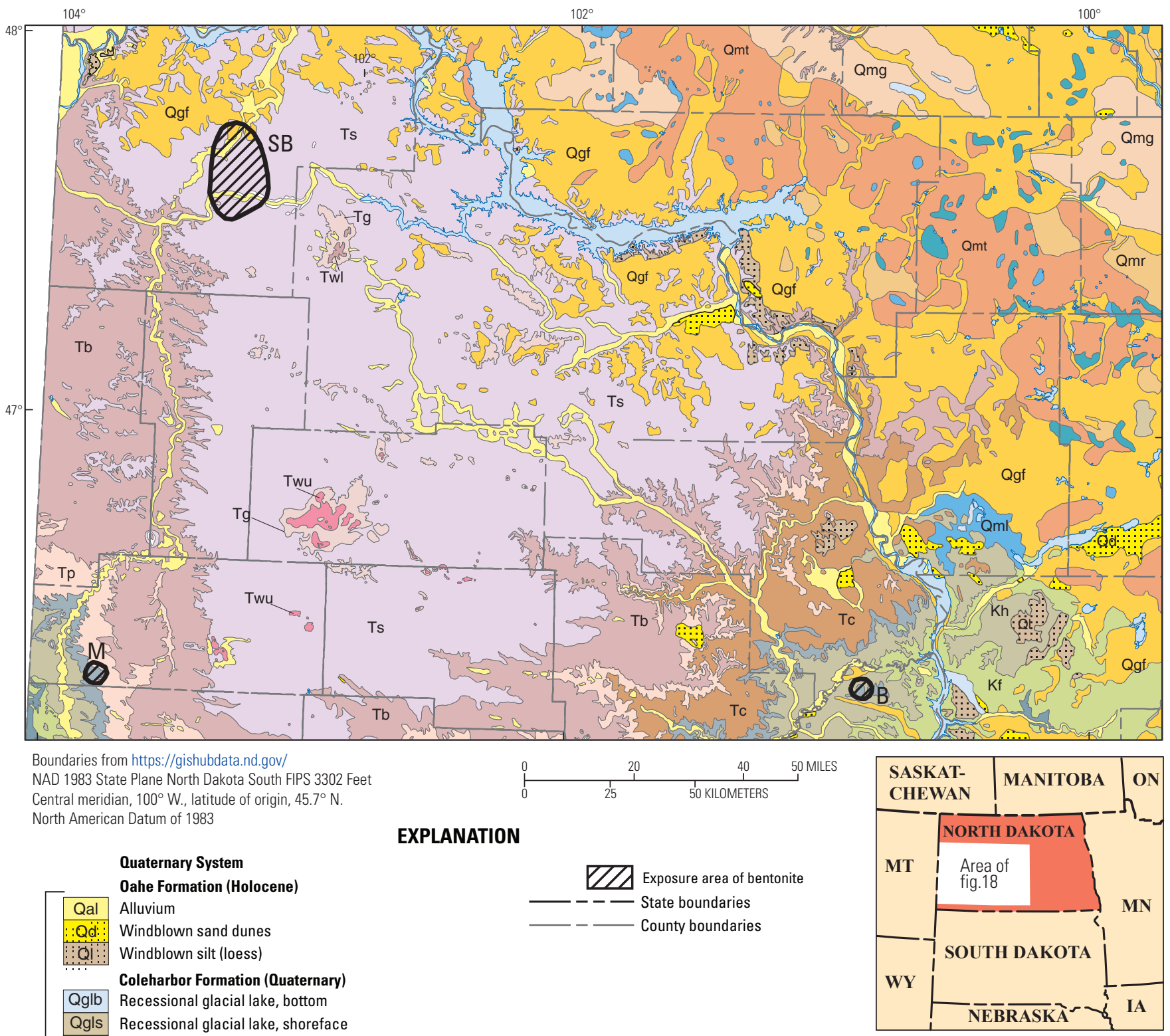

Mix of proglacial outwash sediment and pre-Late Wisconsin till

Glacial thrust ridge

Terminal moraine

Qmr Recessional moraine

Qmg Ground moraine

\section{Tertiary System}

Twu White River Group, Upper-Pinkish river and lake sediments, mainly siltstone

Twl White River Group, Lower-Pale river and lake sediments, mainly sandstone

$\mathrm{Tg}$ Golden Valley Formation-Yellowish-brown river, lake, and swamp deposits that have thin lignite and locally kaolinitic claystone

Ts Sentinel Butte Formation-Somber grayish-brown river, lake, and swamp deposits that have bentonitic clays and lignite

b Bullion Creek Formation-Brightly colored river, lake, and swamp deposits that have bentonitic clays and lignite

Slope Formation-Dark river, lake, and swamp deposits that have lignite and kaolinitic claystones

Cannonball Formation-Dark marine mudstone and greenish sandstone

Ludlow Formation - Gray river, lake, and swamp deposits that have lignite and kaolinitic claystones Cretaceous System

Hell Creek Formation-Somber grey, brown and purple river, lake, and swamp deposits with bentonitic clays

Fox Hills Formation-Dark reddish -rown marine mudstone and yellow-brown sandstone

Pierre Formation-Gray marine shale that have thick bentonite near base

Niobrara and Carlile Formation, undivided—Gray calcareous marine shale

Figure 18. Map showing distribution of major known bentonite beds in southwestern North Dakota, overlain on geologic map (modified from Forsman, 1992; Murphy, 1995; see fig. 4, this report, for explanation of geologic units). Stratigraphic classification from Clayton and others (1977), Murphy and others (2009). Bentonite beds: $B$, Breien bentonite bed, in basal part of the Cretaceous Fox Hills Formation; M, Marmarth bentonite bed, near top of the Cretaceous Hell Creek Formation; SB, Sentinel Butte bentonite bed, in middle of the Paleocene Sentinel Butte Formation. 
from distant sources), and their replacement by lower quality but still adequate local or regional natural sand proppant sources, may render the abundant sand deposits in North Dakota a viable replacement in the future.

\section{Bentonite}

Bentonite is a rock composed predominantly of smectitegroup clays, especially montmorillonite, giving it a greasy, soaplike feel. It typically forms from the weathering of layers of volcanic ash, although sometimes the name is given to clay beds of uncertain origin (Grim and Guven, 1978). Bentonite has many uses, but its main uses in 2019 (U.S. Geological Survey, 2019) were in pet waste absorbents (53 percent) and drilling mud (31 percent).

Bentonitic tuffs (altered volcanic ash layers) are scattered throughout the Late Cretaceous and early Tertiary strata exposed in southwestern North Dakota (Forsman, 1992). Murphy (1995) listed three major bentonites, the Marmouth bentonite in Slope County, the Breien bentonite in Sioux County, and the "blue bed" bentonite in Theodore Roosevelt National Park in McKenzie County (fig. 18). These volcanic ash layers originated as airfall tuffs from distant Rocky Mountain eruptions and such tuffs typically have substantial lateral extent. Although none of these bentonites have been exploited commercially, neither these strata nor other tuff-associated bentonites have been evaluated for their commercial potential, as far as we have found in the literature.

The Marmouth bentonite is found as two horizons, a few meters below the top of the Upper Cretaceous Hell Creek Formation in Slope County (Forsman, 1992; fig 18, this report). The upper horizon is $0.61 \mathrm{~m}(2 \mathrm{ft})$ thick; the lower one is $1.8 \mathrm{~m}(6 \mathrm{ft})$ thick, and they are separated by 1.5

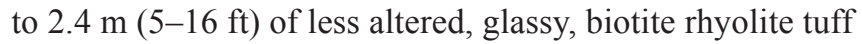
(Murphy, 1995). The areal extent of the bentonite horizons is estimated to be as much as 13 square kilometers $\left(\mathrm{km}^{2}\right)$ 5 square miles $\left[\mathrm{mi}^{2}\right]$ ).

The Breien bentonite occurs in the upper part of the Upper Cretaceous Fox Hills Formation (Murphy, 1995) or possibly in the basal part of the Hells Creek Formation (Hoganson and Murphy, 2002) in Sioux County (Murphy, 1995; fig. 18, this report). The bentonite is 0.61 to $0.91 \mathrm{~m}$ (2-3 ft) thick and overlies a white rhyolitic tuff that contains fossilized sequoia stumps in growth position. The bentonite horizon can be traced for about $7.8 \mathrm{~km}$ ( $3 \mathrm{mi}$ ) eastward from western exposures near the town of Breien.

The "blue bed" bentonite is a prominent bench-forming bentonite in the Paleogene Sentinel Butte Formation, in Theodore Roosevelt National Park, McKenzie County (Murphy, 1995; fig. 18, this report). It is part of a pair of bentonite horizons that both overlie and underlie a grayishwhite felsic tuff (Forsman, 1992). The lower bentonite, as much as $3.7 \mathrm{~m}(12.1 \mathrm{ft})$ thick, forms a prominent topographic bench through the badlands terrain. The upper bentonite ranges

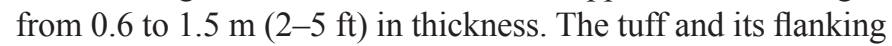
bentonites can be visually traced throughout an area of nearly $1,500 \mathrm{~km}^{2}\left(580 \mathrm{mi}^{2}\right)$ south and west of Watford City (fig. 1).

\section{Manganese}

A few prospects of manganese minerals are known from the south flank of the Turtle Mountains, near the north-central border of North Dakota (fig. 12; Hendricks and Laird, 1943; Anderson, 1973). The manganese is present within calcareous cold-spring deposits, in the form of a hydrous calciummanganese oxide (rancieite). Hendricks and Laird (1943) reported analyses of eight samples of manganese ore from one deposit, which range from 3.2 to 23.8 percent manganese and average about 10 percent. The deposits are small and relatively low grade, and no mining of these deposits has ever occurred.

\section{Leasable Commodities}

The most prominent leasable commodities in North Dakota are oil, gas, and coal, but these are not considered here. We consider here only the non-energy leasable mineral resources: potash, helium, and sodium sulfate. Potash and helium are trapped in deep Williston Basin strata and must be recovered by drilling. Both have been identified as having the potential for commercial accumulations in North Dakota but neither has ever been commercially produced in the State.

\section{Potash}

The potash deposits of North Dakota remain an untapped resource, a deeper repository of the rich deposits now being mined in Williston Basin strata in Saskatchewan (Kruger, 2019a). Saskatchewan is the largest potash producer in the world, accounting for approximately 30 percent of total global production (Jasinski, 2019). The term "potash" refers to a variety of potassium-bearing salts within layered evaporitic salt deposits composed primarily of sodium chloride, or halite (Anderson and Swinehart, 1979). In southern Saskatchewan and northwestern North Dakota ("Elk Point Basin"), potash deposits lie within the Middle Devonian Prairie Formation, which in North Dakota is at depths from 1,700 m (5,600 ft) to more than $3,800 \mathrm{~m}$ (12,500 ft) (Kruger, 2014). Potash below $1,110 \mathrm{~m}(3,600 \mathrm{ft})$ is typically mined by solution methods through wells.

North Dakota is estimated to contain nearly 6.35 billion tonnes ( 7 billion tons) of $\mathrm{K}_{2} \mathrm{O}$, about 3 percent of the world's total potash resources (Jasinski, 2019). Potash is found in the following six horizons in the Prairie Formation in North Dakota (listed from lower to higher, stratigraphically): the Esterhazy, White Bear, Belle Plaine, Patience Lake, Mountrail, and White Lake Members. Kruger (2014) produced a series of maps of the distribution, thicknesses, and gamma ray intensities (a surrogate for potassium content) of these six members. A composite map showing where each of the lower

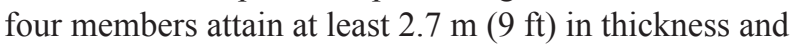
record gamma ray counts of at least 100 American Petroleum Industry gamma ray units (GAPI; roughly 10 percent $\mathrm{K}_{2} \mathrm{O}$ or greater; Nelson, 2007) is provided in figure 19.

The NDGS issued a subsurface mineral permit for potash exploration in 2010 (Murphy, 2011), and a well was completed 


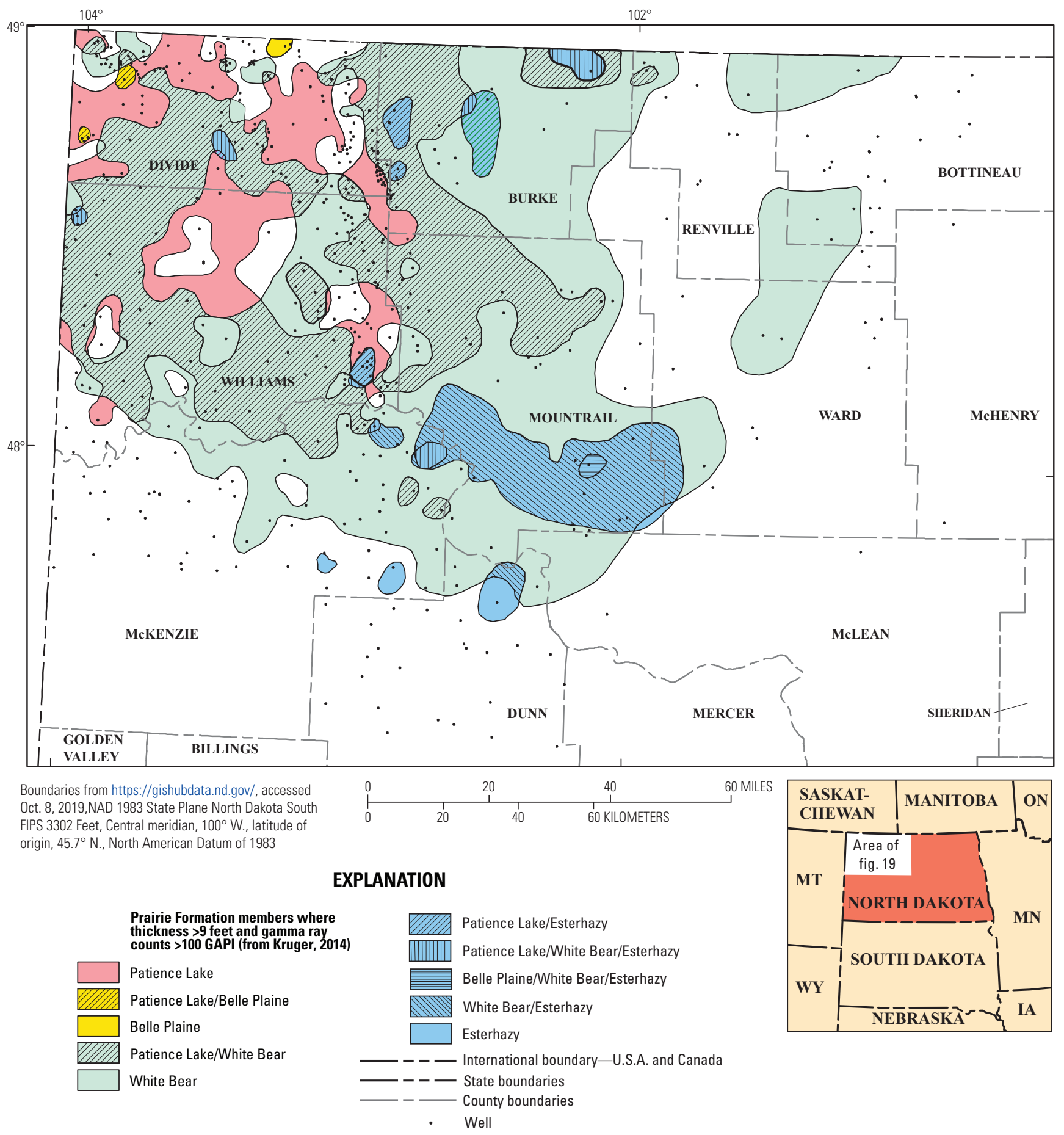

Figure 19. Map showing sub-surface distribution of members of the Prairie Formation in northwestern North Dakota where potash thickness is greater than 9 feet and gamma ray counts are greater than 100 American Petroleum Industry gamma ray units (GAPI), indicating $\mathrm{K}_{2} \mathrm{O}$ content is about 10 percent or greater (Nelson, 2007; Kruger, 2014). 


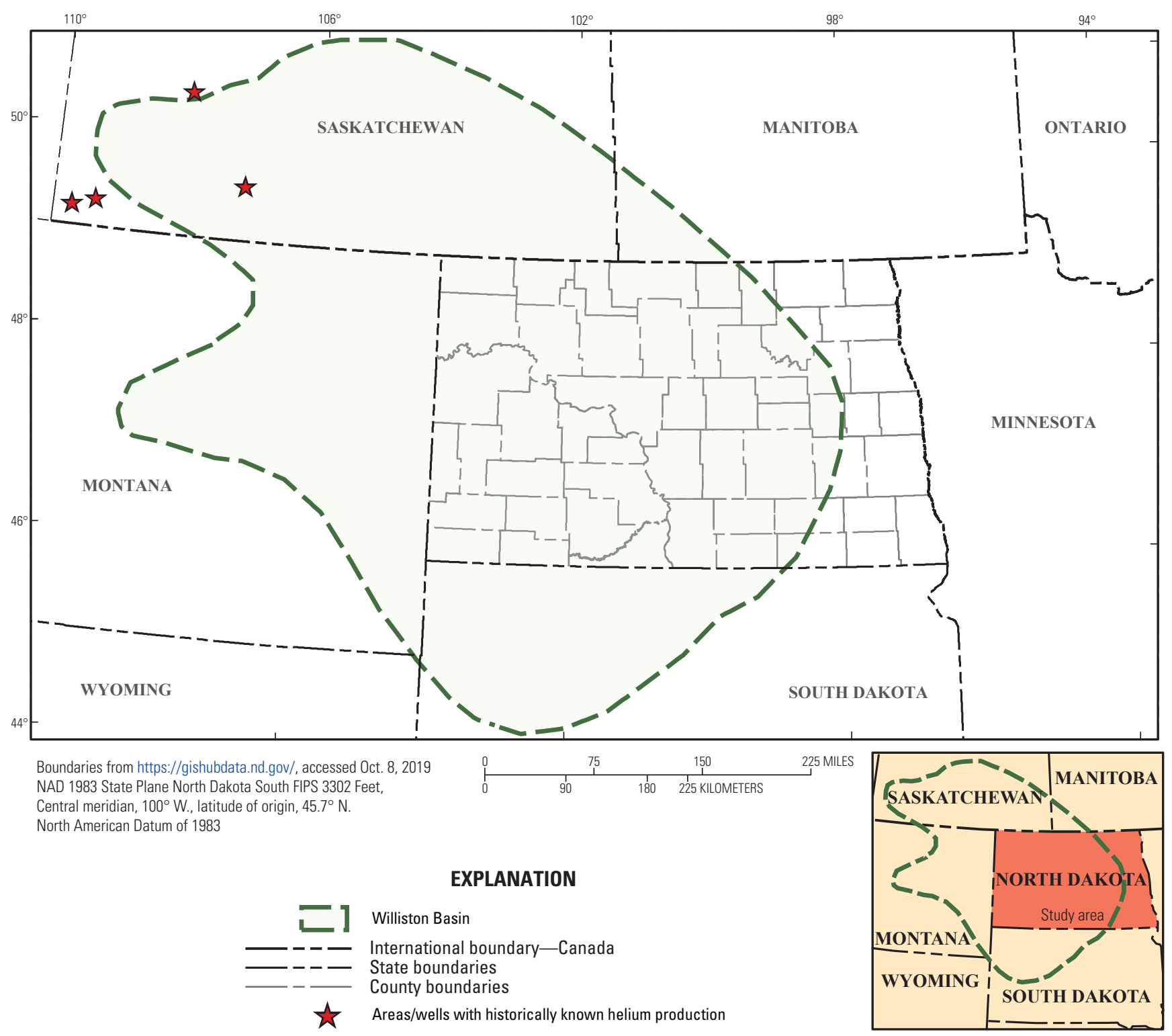

Figure 20. Map showing helium production wells in Saskatchewan, Canada, in and adjacent to Williston Basin (modified from Yurkowski, 2016).

near Lignite in Burke County to 2,794 m (9,167 ft) (Kruger, 2014). The well intersected $8.5 \mathrm{~m}$ (28 ft) of potash-bearing salt in the Esterhazy Member, which had an average grade of 11.8 percent $\mathrm{K}_{2} \mathrm{O}$. However, the company dropped the lease in 2012. At least four earlier potash-exploration drill holes were completed in northwestern North Dakota. One well was drilled near Lignite in 1962. Three additional potash-exploratory wells were drilled in 1976, two in Burke County and one in Bottineau County. Despite the limited exploration, no potash has ever been produced in North Dakota.

\section{Helium}

The helium potential of the Williston Basin was first discovered in 1952 in the Canadian part of the Williston
Basin in southwestern Saskatchewan (Yurkowski, 2016). Helium was produced from four wells in Saskatchewan (fig. 20; modified from Yurkowski, 2016) from 1963 to 1977; production in the area resumed in 2014. The typical gas compositions produced for helium in these Canadian wells were only 1 to 2 percent helium and more than 90 percent nitrogen gas $\left(\mathrm{N}_{2}\right)$. The gas is generally found in the basal Cambrian and Ordovician strata, close to the basal contact of stratified sedimentary rocks above crystalline basement. The wells in Saskatchewan have produced about 60 million cubic meters $\left(\mathrm{m}^{3}\right)\left(2,120\right.$ million cubic feet $\left.\left[\mathrm{ft}^{3}\right]\right)$ of gas. This has resulted in recent interest in helium exploration in the North Dakota part of the Williston Basin (Kruger, 2019b).

Most helium in the crust is generated by the radioactive decay of uranium and thorium and so is produced over very 
long periods. Helium is an inert gas that is found in at least trace amounts in most natural (hydrocarbon) gas produced on earth (Rogers, 1921), and it can be effectively separated when natural gas is liquified for transport (Yurkowski, 2016). Helium can also be present at higher concentrations (by a few percentage points) in nitrogen-rich (that is, 20-95 percent $\mathrm{N}_{2}$ ) gases, which may also contain $\mathrm{CO}_{2}$. These He- $\mathrm{N}_{2}$ gases are preferentially sought for helium production. Although the physical processes required to trap economic amounts of helium (source, migration, carrier beds, and trap with seal) are similar to those of hydrocarbon natural-gas traps, helium differs from hydrocarbon gases in the following two ways: it has a nonorganic source, and it is a very small molecule, which means that it requires a more robust seal for its reservoir than most hydrocarbons do, as a helium molecule is roughly half the size of a methane molecule.

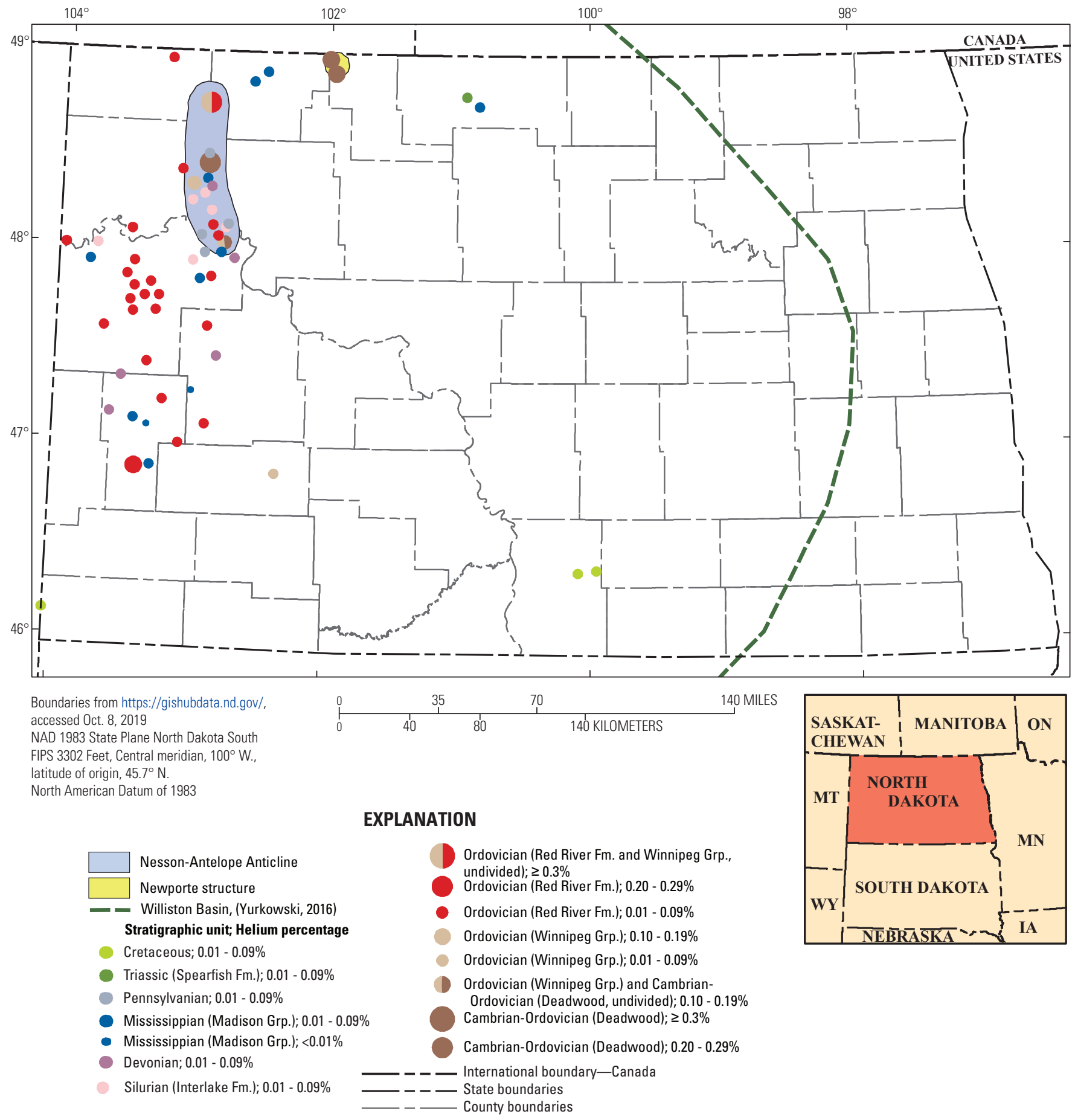

Figure 21. Map showing helium gas concentrations in drill holes by stratigraphic unit (modified from Nesheim and Kruger, 2019) in North Dakota, from drill hole data (data from Bureau of Land Management database). 
The NDGS recently compiled a limited set of gas analyses from North Dakota from the national BLM database (Nesheim and Kruger, 2019). Sixty-five gas sample compositions from western North Dakota were reported in that database, and all but three had detectable helium. Eight samples had helium values greater than 0.1 percent, and all of those came from basal Cambrian and Ordovician strata (fig. 21, modified from Nesheim and Kruger, 2019, their fig. 1) and were primarily positioned along either the trend of the Nesson-Antelope Anticline or the Newporte structure. As with the helium-bearing gases from the Canadian part of the Williston Basin, it is inferred that the helium in these deep strata is sourced from the underlying, relatively uranium-rich Early Proterozoic (1,800 Ma) granitic basement rocks.

Yurkowski (2016) proposed a model for the occurrences of helium within the Williston Basin that had the following three components: (1) helium generation through the radioactive decay of uranium and thorium in Precambrian granitic rocks,
(2) upward migration along fracture and (or) fault systems, and (3) entrapment along anticlinal folds in the overlying Paleozoic Williston Basin strata. The Williston Basin is underlain by variable types of igneous and metamorphic basement rocks, which range from mafic to felsic in composition (Sims and others, 1991). The Nesson-Antelope Anticline roughly overlies a north-south-trending, elongate magnetic high within the Tabbernor Fold and Fault Zone (fig. 19) that apparently reflects a magnetic granitic body within the zone (Sims and others, 1991). The Tabbernor Fold and Fault Zone may form migration pathways for helium from the Precambrian basement rocks into the overlying sedimentary formations (Nesheim and Kruger, 2019). The Nesson and Antelope structures are anticlines that could potentially trap and accumulate helium. The Newporte structure, however, has been interpreted as an astrobleme (meteorite impact structure) that disrupted Precambrian bedrock (creating migration pathways) and, in the deeper sedimentary formations, resulted in the development of

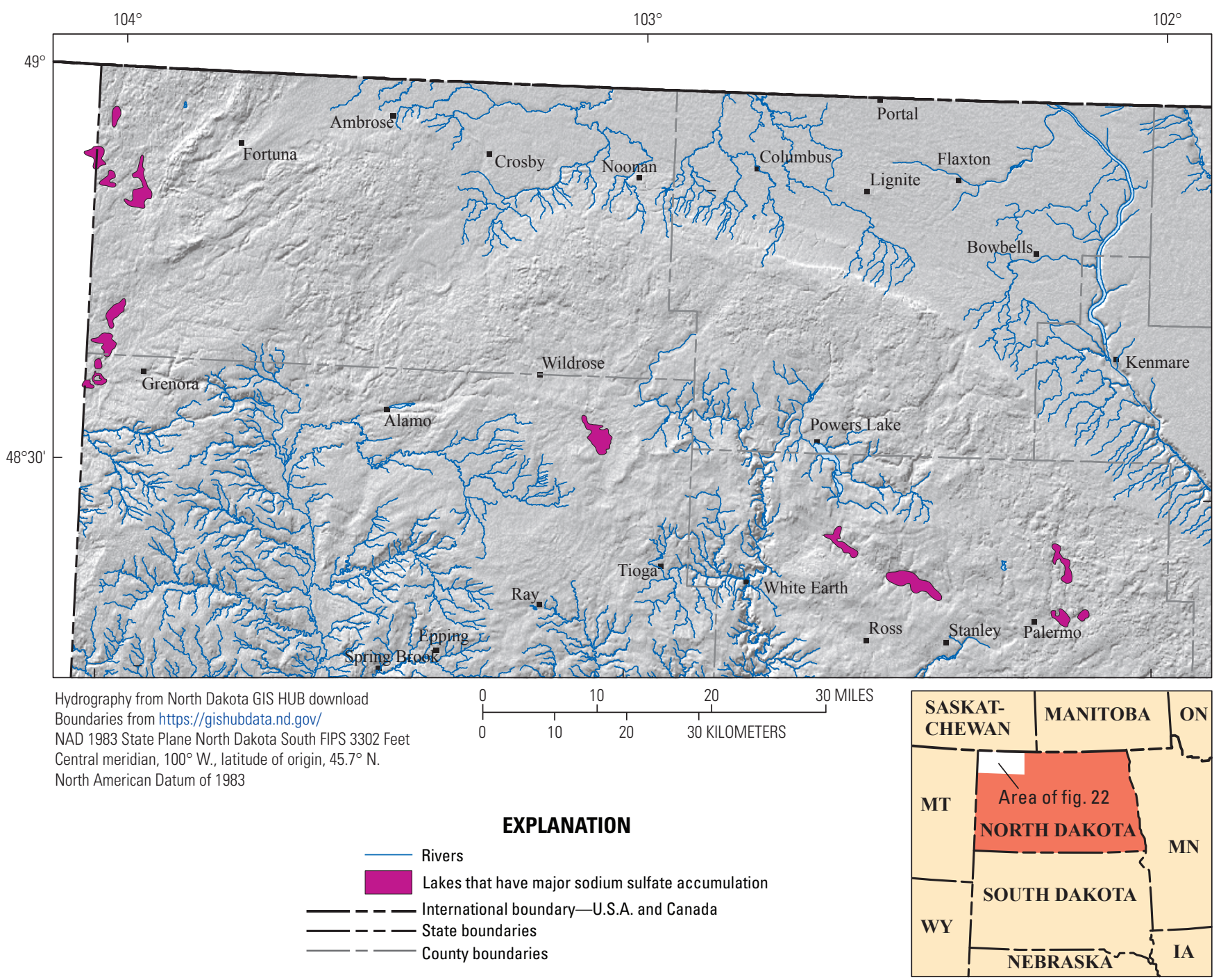

Figure 22. Shaded-relief map showing distribution of major sodium sulfate deposits in lakes in northwestern North Dakota (modified from Murphy, 1996). 
semispherical, concentric ridges (structural highs capable of helium entrapment) (Forsman and others, 1996). The elevated helium concentrations along the Nesson-Antelope Anticline and the Newporte structure may, therefore, fit with the previously proposed model of Yurkowski (2016) for basement-derived helium accumulations. On the basis of the limited helium gas data from North Dakota, other helium gas plays in the Williston Basin strata in the State are possible.

\section{Sodium Sulfate}

Hydrated sodium sulfate salts ("Glauber salt") in small lakes along the Missouri River in northwestern North Dakota first entered western literature in the notes of the Lewis and Clark expedition of 1804-06. Between the 1930s and 1990s, Federal and State agencies analyzed thousands of samples augered from the bottoms of about 15 small evaporitic lakes in that area (Binyon, 1952; Murphy, 1996). It was estimated that about 41.7 million metric tonnes (46 million tons) of Glauber salt reside beneath these lakes (fig. 22), having accumulated on deposits of the last glaciation since about 12,000 yr ago. Sodium sulfate has been produced historically across the Canadian border in Saskatchewan, with annual production peaking at more than half a million metric tonnes (0.55 tons) in 1982. Sodium sulfate has been used in the pulp and paper industry, in detergents, and in the production of both food-grade and non-food-grade sodium bicarbonate (baking soda) (Bajpai, 2015).

\section{Salable Commodities}

Salable commodities consist of the common varieties of sand, gravel, stone, pumice, cinders, clay, and crushed stone used for construction activities, which are typically extracted in a surface-mining operation. From various databases for North Dakota, we have identified between 4,000 and 5,100 existing borrow pits or quarries for sand, gravel, and associated commodities (fig. 14) widely scattered across the State. They are not limited to the mapped Quaternary unconsolidated geologic units on the geologic map (fig. 3), but they can be found in essentially any surficial geologic unit in North Dakota, most of which are only weakly consolidated. Notable geologic associations that have clusters of existing localities (fig. 14) are the linear arrays of points north and west of Fargo, in the Red River of the North Valley, which are associated with sandy, recessional shoreline deposits of Glacial Lake Agassiz (Landis, 1973). Other glacial landforms that can contain commercial-grade sand and gravel are kames and eskers, features that are easily identifiable using lidar imagery (Maike, 2017). Most areas of the State have available resources for construction materials.

\section{Summary}

The geology of North Dakota, along with its identified and potential nonfuel mineral resources (especially those identified as Critical Minerals), represents a long and complex geologic history that extends back more than 3 billion years. Beyond construction-aggregate materials, the value of nonfuel mineral commodities that have been produced in North Dakota is small, although there is potential for the existence of several deposit types that are not economically viable at this time. Future increases in the value of these commodities might someday lead to their exploitation.

\section{References Cited}

Anderson, F.J., 2009, Depth to Precambrian basement in North Dakota: North Dakota Geological Survey Geologic Investigation 85, scale 1:750,000.

Anderson, F.J., 2018a, Evaluation of eolian sands in North Dakota for proppant use: North Dakota Geological Survey GeoNews, v. 45, no. 2, p. 11-13.

Anderson, F.J., 2018b, Eolian sands in North Dakota evaluated for use as natural sand proppant for oil and gas wells: North Dakota Geological Survey Geologic Investigation 207, $70 \mathrm{p}$.

Anderson, F.J., 2019a, Central North Dakota's eolian sands evaluated as potential natural proppant sand alternative: North Dakota Geological Survey GeoNews, v. 47, no. 2, p. $10-12$.

Anderson, F.J., 2019b, The potential of the Hazen-Stanton Dunes for use as natural sand proppant: North Dakota Geological Survey Geologic Investigation 216, 15 p.

Anderson, F.J., Moxness, L.D., Kruger, N.W., Murphy, E.C., and Maike, C.A., 2019, Sieve analysis of selected LateCretaceous and Tertiary (Paleocene) bedrock sandstones in North Dakota for potential use as proppant: North Dakota Geological Survey Geologic Investigation 218, 34 p.

Anderson, S.B., 1973, Manganese in Landis, E.R., ed., Mineral and water resources of North Dakota: North Dakota Geological Survey Bulletin 63, p. 158-159.

Anderson, S.B., and Swinehart, R.P., 1979, Potash salts in the Williston Basin, U.S.A.: Economic Geology, v. 74, p. 358-379.

Anna, L.O., Pollastro, R, and Gaswirth, S.B., 2013, Williston Basin province-Stratigraphic and structural framework to a geologic assessment of undiscovered oil and gas resources, chap. 2 of U.S. Geological Survey Williston Basin Province Assessment Team, Assessment of undiscovered oil and gas resources of the Williston Basin province of North Dakota, Montana, and South Dakota, 2010: U.S. Geological Survey Digital Data Series DDS 69-W, p. 1-17.

Bader, J.W., 2019, An ancient Everest—Precambrian basement terranes of the Williston Basin: North Dakota Geological Survey GeoNews, v. 46, no. 1, p. 30-34. 
Bajpai, P., 2015, Pulp and paper industry-Chemicals: New York, Elsevier, 327 p.

Bedrosian, P., and Finn, C., 2019, When Wyoming became Superior-Geophysical imaging of the Trans-Hudson orogen [abs.]: American Geophysical Union Fall Meeting, abs. T12A-05.

Binyon, E.O., 1952, North Dakota sodium sulfate deposits: U.S. Bureau of Mines Report of Investigations 4880, 8 p.

Bluemle, J.P., 1977, The face of North Dakota - The geologic story: North Dakota Geological Survey Educational Series $11,73 \mathrm{p}$.

Bluemle, J.P., 1983, Geologic and topographic bedrock map of North Dakota: North Dakota Geological Survey Miscellaneous Map 25, scale 1:670,000.

Bluemle, J.P., 1988, Guide to the geology of north-central North Dakota: North Dakota Geological Survey Educational Series 19, $47 \mathrm{p}$.

Brennan, S.T., Burruss, R.C., Merrill, M.D., Freeman, P.A., and Ruppert, L.F., 2010, A probabilistic assessment methodology for the evaluation of geologic carbon dioxide storage: U.S. Geological Survey Open-File Report 20101127, 31 p., http://pubs.usgs. gov/of/2010/1127.

Clayton, L., Carlson, C.G., Moore, W.L., Groenewold, G., Holland, F.D., and Moran, S.R., 1977, The Slope (Paleocene) and Bullion Creek (Paleocene) Formations of North Dakota: North Dakota Geological Survey Report of Investigation 59, 14 p.

Clayton, L., Moran, S.R., Bluemle, J.P., and Carlson, C.G., 1980a, Geologic map of North Dakota: U.S. Geological Survey, scale 1:500,000.

Clayton, L., Moran, S.R., and Bluemle, J.P., 1980b, Explanatory text to accompany the geologic map of North Dakota: North Dakota Geological Survey Report of Investigation 69, $93 \mathrm{p}$.

Coleman, J.L., Jr., and Cahan, S.M., 2012, Preliminary catalog of the sedimentary basins of the United States: U.S. Geological Survey Open-File Report 2012-1111, 27 p. (plus 4 figures and 1 table available as separate files), accessed November 13, 2019, at http://pubs.usgs.gov/of/2012/1111/.

Colton, R.B., Lemke, R.W., and Linvall, R.M., 1963, Preliminary glacial map of North Dakota: U.S. Geological Survey Miscellaneous Geologic Investigations Map I-331, scale 1:500,000.

Dahl, P.S., Terry, M.P., Jercinovic, M.J., Williams, M.L., Hamilton, M.A., Foland, K.A., Clement, S.M., and Friberg, L.M., 2005, Electron probe (ultrachron) microchronometry of metamorphic monazite-Unraveling the timing of polyphase thermotectonism in easternmost Wyoming Craton (Black Hills, South Dakota): American Mineralogist, v. 90, p. 1712-1728.
Denson, N.M., Gill, J.R., and Chisholm, W.A., 1965, Uranium-bearing lignite and carbonaceous shale in the southwestern part of the Williston Basin-A regional study, with a section on Heavy minerals in Cretaceous and Tertiary rocks associated with uranium occurrences: U.S. Geological Survey Professional Paper 463, 76 p.

Denson, N.M., and Chisholm, W.A., 1971, Summary of mineralogic and lithologic characteristics of Tertiary sedimentary rocks in the middle Rocky Mountains and northern Great Plains: U.S. Geological Survey Professional Paper 750-C, p. 117-126.

Farris, R.A., 1984, Heavy minerals of the Cretaceous Hell Creek and Paleocene Ludlow Formations of Slope and Bowman Counties, North Dakota: Grand Forks, University of North Dakota, M.A. thesis, 109 p.

Forsman, N.F., 1992, Tuffs in North Dakota, in Erickson, J.M., and Hoganson, J.W., eds., Proceedings of the F.D. Holland, Jr. Geological Symposium, 1992, p. 267-272.

Forsman, N.F., Gerlach, T.R., and Anderson, N.L., 1996, Impact origin of the Newporte structure, Williston Basin, North Dakota: AAPG Bulletin, v. 80, no. 5, p. 721-730.

Franus, W., Wiatros-Motyka, M.M., and Wdowin, M., 2015, Coal fly ash as a resource for rare earth elements: Environmental Science and Pollution Research, v. 22, p. 9464-9474.

Fullerton, D.S., 1995, Quaternary geologic map of the Dakotas $4^{\circ} \times 6^{0}$ quadrangle, United States: U.S. Geological Survey Miscellaneous Investigations Series Map I-1420 (NL-14), scale 1:1,000,000, 33-p. pamphlet.

Grim, R.E., and Guven, N., 1978, Bentonites-Geology, mineralogy and uses: Developments in Sedimentology, v. $24,255 \mathrm{p}$.

Hansen, D.E., 1964, Germanium, in Mineral resources of North Dakota: North Dakota Economic Development Commission, Conference at the University of North Dakota, Jan. 28-29, p.109-110.

Hendricks, T.A., and Laird, W.M., 1943, The manganese deposits of the Turtle Mountains, North Dakota: Economic Geology, v. 38, p. 591-602.

Hoganson, J.W., and Murphy, E.C., 2002, Marine Breien Member (Maastrichtian) of the Hell Creek Formation in North Dakota - Stratigraphy, vertebrate fossil record, and age, in Hartman, J.H., Johnson, K.R., and Nichols, D.J., eds., The Hell Creek Formation and the Cretaceous-Tertiary boundary in the northern Great Plains - An integrated continental record of the end of the Cretaceous: Boulder, Colo., Geological Society of America Special Paper 361, p. 247-269. 
Hunt, L., Stachel, T., Grutter, H., Armstrong, J., McCandless, T.E., Simonetti, A., and Tappe, S., 2012, Small mantle fragments from the Renard kimberlites, Quebec-Powerful recorders of mantle lithosphere formation and modification beneath the Eastern Superior Craton: Journal of Petrology, v. 53, no. 8, p. 1597-1635.

Jasinski, S.M., 2019, Potash, in Mineral commodity summaries 2019: U.S. Geological Survey Mineral Commodity Summaries, p. 126-127, accessed October 27, 2019, at https://doi.org/10.3133/70202434.

Kent, D.M., and Christopher, J.E., 1994, Geological history of the Peace River Arch, in Mossop, G.D., and Shetsen, I., comps., Geological atlas of the Western Canada Sedimentary Basin: Canadian Society of Petroleum Geologists and Alberta Research Council, accessed November 13, 2019, at https://ags.aer.ca/publications/ chapter-28-geological-history-of-the-peace-river-arch.htm.

Klasner, J.S., and King, E.R., 1986, Precambrian basement geology of North and South Dakota: Canadian Journal of Earth Sciences, v. 23, p. 1083-1102.

Kruger, N.W., 2014, The potash members of the Prairie Formation in North Dakota: North Dakota Geological Survey Report of Investigations 113, 39 p.

Kruger, N.W., 2015, A "rare" opportunity: North Dakota Department of Mineral Resources GeoNews, v. 42, no. 1, p. 7-8.

Kruger, N.W., 2017, Rare earths in coal: North Dakota Department of Mineral Resources GeoNews, v. 44, no. 1, p. $10-12$.

Kruger, N.W., 2019a, The potash report: North Dakota Department of Mineral Resources GeoNews, v. 46, no. 1, p. 20-22.

Kruger, N.W., 2019b, Helium listed as a Critical Mineral: North Dakota Department of Mineral Resources GeoNews, v. 46 , no. 2 , p. 1-3.

Kruger, N.W., Moxness, L.D., and Murphy, E.C., 2017, Rare earth element concentrations in Fort Union and Hell Creek strata in western North Dakota: North Dakota Geological Survey Report of Investigations 117, 104 p.

Landis, E.R., ed., 1973, Part 1-Geology and mineral resources, in U.S. Geological Survey and U.S. Bureau of Reclamation, eds., Mineral and Water Resources of North Dakota: North Dakota Geological Survey Bulletin 63, p. $1-160$.

Lewry, J.F., Hajnal, Z., Green, A., Lucas, S.B., White, D., Stauffer, M.R., Ashton, K.E., Weber, W., and Clowes, R., 1994, Structure of a Paleoproterozoic continent-continent collision zone-A LITHOPROBE seismic reflection profile across the Trans-Hudson orogen, Canada: Tectonophysics v. 232, p. $143-160$.
Maike, C., 2017, Surface mapping of sand and gravel and LiDAR applications: North Dakota Department of Mineral Resources GeoNews, v. 44, no. 1, p. 18-19.

McCormick, K.A., 2010, Precambrian basement terrane of South Dakota: Geological Survey of South Dakota Bulletin 41, $37 \mathrm{p}$.

McFaul, E.J., Mason, G.T., Ferguson, W.B., and Lipin, B.R., 2000, U.S. Geological Survey mineral databases; MRDS and MAS/MILS: U.S. Geological Survey Data Series DS-52, 2 compact discs, accessed September 21, 2019, at https://doi.org/10.3133/ds52.

Murphy, E.C., 1995, North Dakota clays - A historical review of clay utilization in North Dakota: North Dakota Geological Survey Miscellaneous Series 99, 18 p.

Murphy, E.C., 1996, The sodium sulfate deposits of northwestern North Dakota: North Dakota Geological Survey Report of Investigations 99, 73 p.

Murphy, E.C., 2007, Uranium deposits in southwestern North Dakota: North Dakota Geological Survey Geologic Investigations 40, scale 1:360,000.

Murphy, E.C., 2009a, Germanium in North Dakota lignites: North Dakota Geological Survey DMR Newsletter, v. 36, no. 1 , p. 14-15.

Murphy, E.C., 2009b, The Golden Valley Formation: North Dakota Geological Survey GeoNews, v. 36, no. 2, p. 1-4.

Murphy, E.C., 2011, Potash in North Dakota: North Dakota Geological Survey GeoNews, v. 38, no. 1, p. 1-4.

Murphy, E.C., 2012a, Southwestern North Dakota kaolinite study: North Dakota Geological Survey GeoNews, v. 39, no. 1, p. 1-2

Murphy, E.C., 2012b, Alumina content of the Bear Den Member and the Rhame Bed in North Dakota: North Dakota Geological Survey Geologic Investigations 158, scale 1:500,000.

Murphy, E.C., 2013, The alumina content of the Bear Den Member (Golden Valley Formation) and the Rhame Bed (Slope Formation) in North Dakota: North Dakota Geological Survey Report of Investigations 112, $271 \mathrm{p}$.

Murphy, E.C., 2019, Rare earth study: North Dakota Geological Survey GeoNews, v. 46, no. 1, p. 1-3.

Murphy, E.C., Hoganson, J.W., and Forsman, N.F., 1993, The Chadron, Brule, and Arikaree Formations in North Dakota: North Dakota Geological Survey Report of Investigation 96, 144 p.

Murphy, E.C., Moxness, L.D., Kruger, N.W. and Maike, C.A., 2018, Rare earth element concentrations in the Harmon, Hanson, and H Lignites in Slope County, North Dakota: North Dakota Geological Survey Report of Investigations 119,46 p. 
Murphy, E.C., Nordeng, S.H., Juenker, B.J., and Hoganson, J.W., 2009, North Dakota stratigraphic column: North Dakota Geological Survey Miscellaneous Series 91, 1 pl.

Nelson, K.D., Baird, D.J., Walters, J.J., Hauck, M., Brown, L.D., Oliver, J.E., Ahem, J.L., Hajnal, Z., Jones, A.G., and Sloss, L.L., 1993, Trans-Hudson orogen and Williston basin in Montana and North Dakota-New COCORP deepprofiling results: Geology, v. 21, p. 447-450.

Nelson, P.H., 2007, Evaluation of potash grade with gammaray logs: U.S. Geological Survey Open-File Report 2007$1292,14 \mathrm{p}$.

Nesheim, T.O., 2012, Review of radiometric ages from North Dakota's Precambrian basement: North Dakota Geological Survey Geologic Investigations 160.

Nesheim, T.O., 2013, Recent diamond exploration in eastern North Dakota: North Dakota Geological Survey GeoNews, v. 40 , no. 1 , p. $5-7$.

Nesheim, T.O., 2014, Mineral exploration history of North Dakota's Precambrian basement: North Dakota Geological Survey GeoNews, v. 41, no. 2, p. 14-16.

Nesheim, T.O., 2016, Review of kimberlite exploration and diamond mine developments along the Superior craton: Implication for eastern North Dakota: North Dakota Geological Survey GeoNews, v. 43, no. 1, p. 7-10.

Nesheim, T.O., and Kruger, N.W., 2019, Helium trends in North Dakota: North Dakota Geological Survey Geologic Investigations $223,10 \mathrm{p}$.

Roehler, H.W., 1989, Origin and distribution of six heavymineral placer deposits in coastal-marine sandstones in the Upper Cretaceous McCourt Sandstone Tongue of the Rock Springs Formation, southwest Wyoming: U.S. Geological Survey Bulletin 1867, 34 p.

Rogers, G.S., 1921, Helium-bearing natural gas: U.S. Geological Survey Professional Paper 121, 113 p.

Sahoo, P.K., Kim, K., Powell, M.A., and Equeenuddin, S.M., 2016, Recovery of metals and other beneficial products from coal fly ash - A sustainable approach for fly ash management: International Journal of Coal Science and Technology, v. 3, p. 267-283, accessed December 9, 2019, at https://doi.org/10.1007/s40789-016-0141-2.

Schneider, D.A., Heizler, M.T., Bickford, M.E., Wortman, G.L., Condie, K.C., and Perilli, S., 2007, Timing constraints of orogeny to cratonization-Thermochronology of the Paleoproterozoic Trans-Hudson orogen, Manitoba and Saskatchewan, Canada: Precambrian Research, v. 153, p. 65-95, accessed December 6, 2019, at https://doi. org/10.1016/j.precamres.2006.11.007.
Schulz, K.J., DeYoung, J.H., Seal, R.R., and Bradley, D.C., eds., 2017, Critical mineral resources of the United StatesEconomic and environmental geology and prospects for future supply: U.S. Geological Survey Professional Paper 1802, 862 p., accessed October 1, 2019, at https://doi. org/10.3133/pp1802.

Seredin, V.V., and Finkelman, R.B., 2008, Metalliferous coals - A review of the main genetic and geochemical types: International Journal of Coal Geology v. 76, p. 253-289, accessed December 9, 2019, at https://doi. org/10.1016/j.coal.2008.07.016.

Seredin, V.V., Dai, S., Sun, Y., and Chekryzhov, I.Y., 2013, Coal deposits as promising sources of rare metals for alternative power and energy-efficient technologies: Applied Geochemistry v. 31, p. 1-11, accessed December 9, 2019 at https://doi.org/10.1016/j.apgeochem.2013.01.009.

Sims, P.K., Peterman, Z.E., Hildenbrand, T.G. and Mahan, S., 1991, Precambrian basement map of the Trans-Hudson orogen and adjacent terranes, northern Great Plains, U.S.A.: U.S. Geological Survey Miscellaneous Investigations Map I-2214, scale 1:1,000,000, 53-p. pamphlet.

Sloss, L.L., 1963, Sequences in the cratonic interior of North America: Geological Society of America Bulletin, v. 74, p. 93-114.

Soller, D.R., and Garrity, C.P., 2018, Map of Quaternary sediment thickness, sheet 1 in Quaternary sediment thickness and bedrock topography of the glaciated United States east of the Rocky Mountains: U.S. Geological Survey Scientific Investigations Map 3392, 2 sheets, scale 1:5,000,000, accessed November 17, 2019, at https://doi. org/10.3133/sim3392.

Stadnichenko, T.M., Murata, K.J., Zubovic, P., and Hufschmidt, E.L., 1953, Concentration of germanium in the ash of American coals, a progress report: U.S. Geological Survey Circular 272, $34 \mathrm{p}$.

Sweeney, R.E., and Hill, P.L., 2003, North Dakota aeromagnetic and gravity maps and data-A Web site for distribution of data: U.S. Geological Survey Open-File Report 03-249, accessed October 2, 2019, at https://pubs. usgs.gov/of/2003/ofr-03-249/.

U.S. Geological Survey, 2019, Mineral commodity summaries 2019: U.S. Geological Survey Mineral Commodity Summaries, 200 p., accessed October 27, 2019, at https:// doi.org/10.3133/70202434.

Van Gosen, B.S., Fey, D.L., Shah, A.K., Verplanck, P.L., and Hoefen, T.M., 2010, Deposit model for heavy-mineral sands in coastal environments: U.S. Geological Survey Scientific Investigations Report 2010-5070-L, 51 p., accessed October 25, 2019, at https://doi.org/10.3133/sir20105070L. 
Waldkirch, R.P., 1999, Physiographic regions of North Dakota: North Dakota Geological Survey Miscellaneous Map 33, scale 1:20,000,000.

Wayne, W.J., Aber, J.S., Agard, S.S., Bergantino, R.N., Bluemle, J.P., Coates, D.A., Cooley, M.E., Madole, R.F., Martin, J.E., Mears, B., Jr., Morrison, R.B., and Sutherland, W.M., 1991, Quaternary geology of the Northern Great Plains, in Morrison, R.B., ed., Quaternary nonglacial geology; Conterminous U.S.: Boulder, Color., Geological Society of America, The Geology of North America, v. K-2, p. 441-476.

Webster, J.R., Kihm, A.J., and Klingbeil, A.A., 2015, Heavy minerals in the late Eocene sandstone of Medicine Pole Hills, southwestern North Dakota: Rocky Mountain Geology, v. 50, no. 1, p. 1-29, accessed December 2, 2019, at https://doi.org/10.2113/gsrocky.50.1.1.
Wehrfritz, B.D., 1978, The Rhame bed (Slope Formation, Paleocene), a silcrete and deep weathering profile, in southwestern North Dakota: Grand Forks, University of North Dakota, M.S. thesis, 158 p., 4 pl.

White, D.J., Thomas, M.D., Jones, A.G., Hope, J., Németh, B., and Hajnal, Z., 2005, Geophysical transect across a Paleoproterozoic continent-continent collision zone-The Trans-Hudson orogen: Canadian Journal of Earth Sciences, v. 42, p. 385-402.

Yurkowski, 2016, Helium in southwestern SaskatchewanAccumulation and geological setting: Saskatchewan Ministry of the Economy, Saskatchewan Geological Survey Open-File Report 2016-1, 20 p.

Zientek, M.L., and Orris, G.J., 2005, Geology and nonfuel mineral deposits of the United States: U.S. Geological Survey Open-File Report 2005-1294-A, 179 p., accessed September 18, 2019, at https://pubs.usgs.gov/of/2005/1294/. 


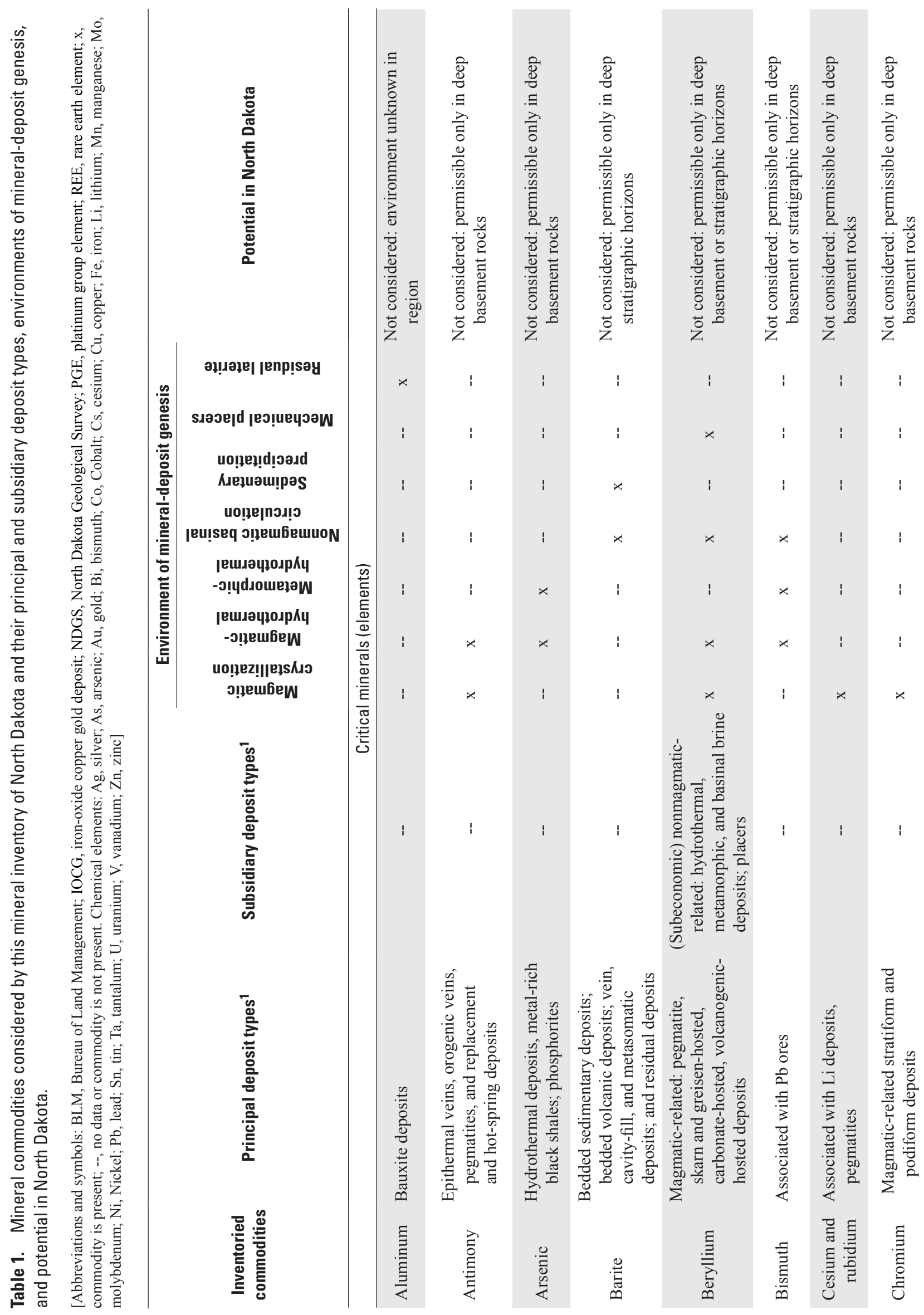




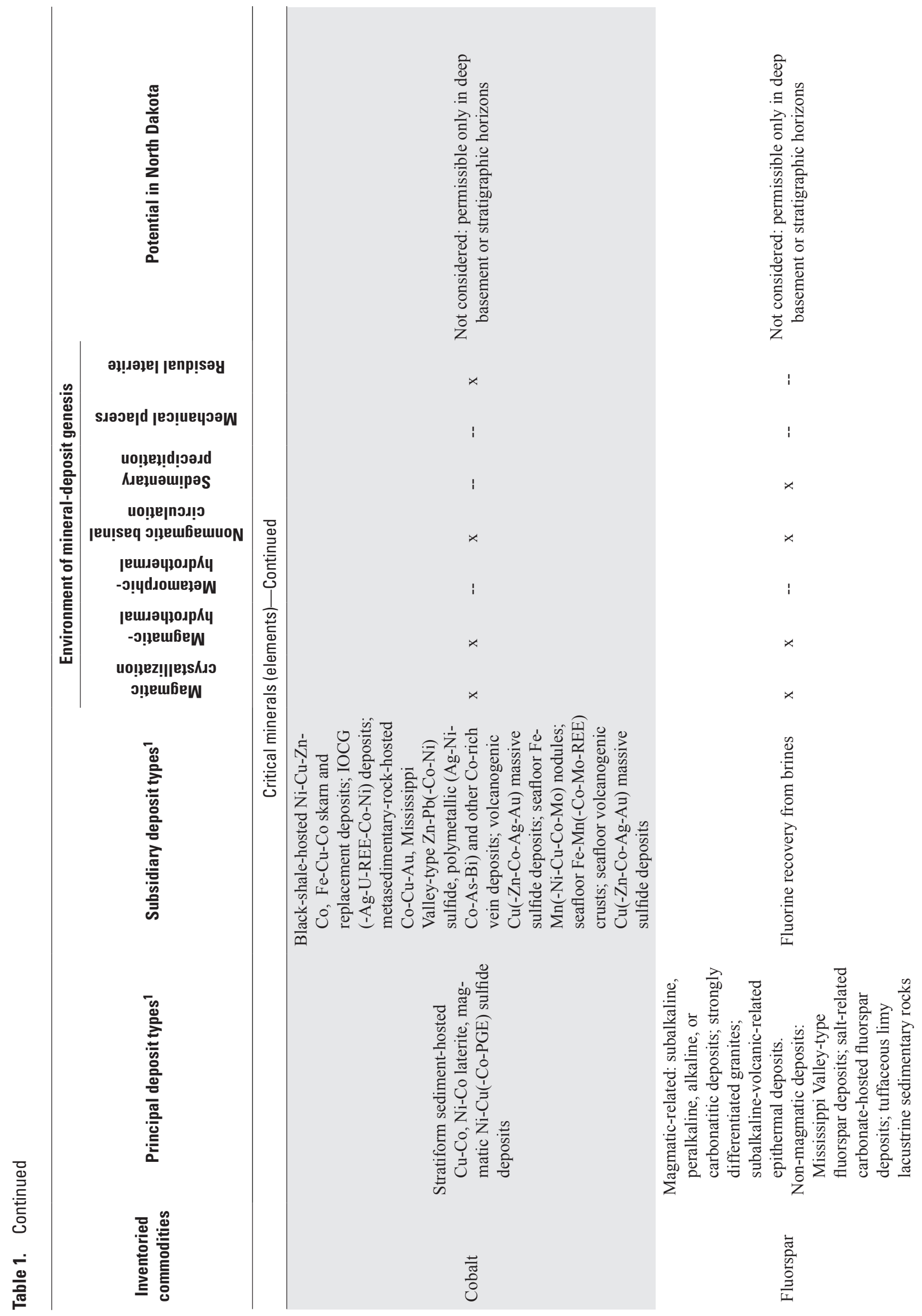




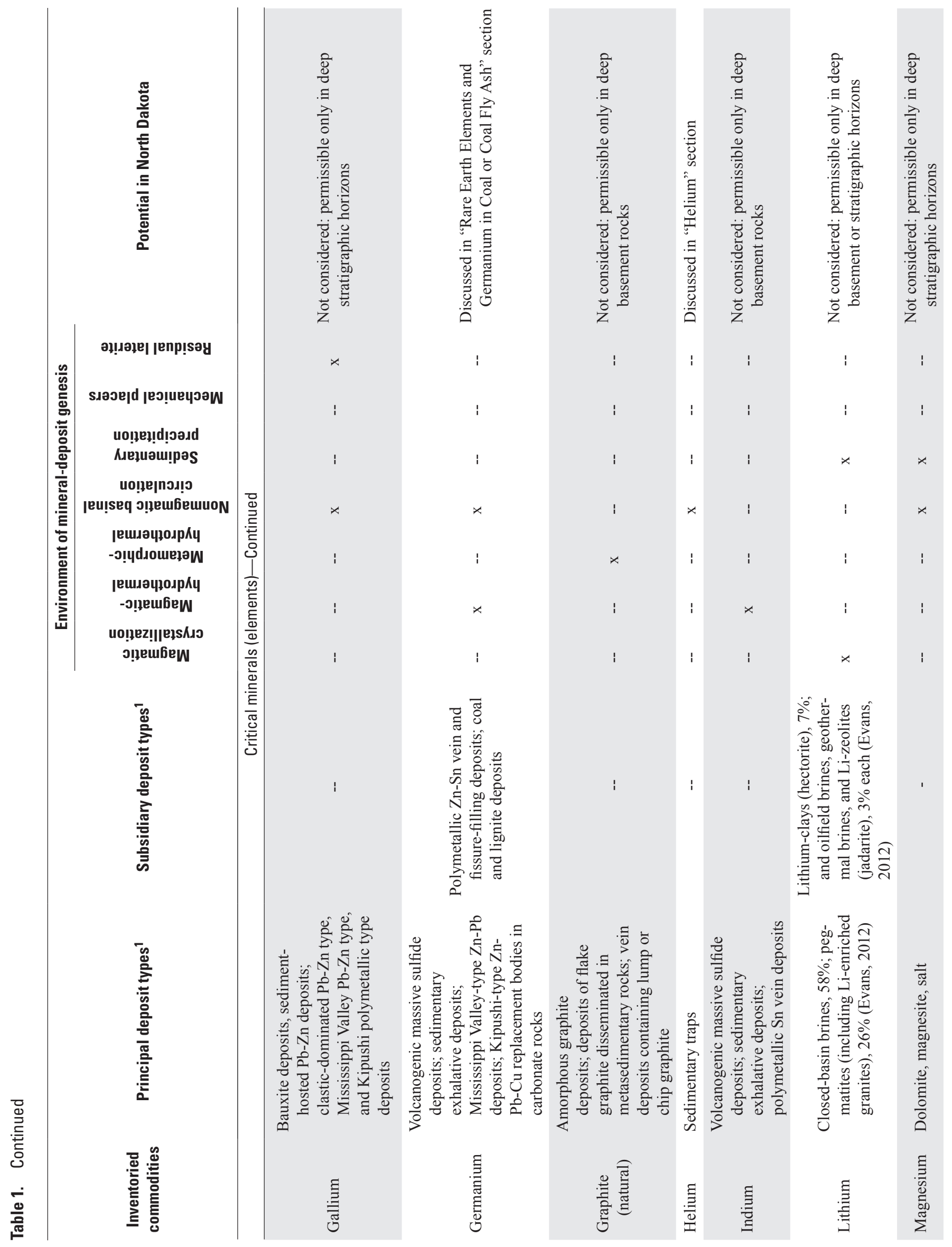




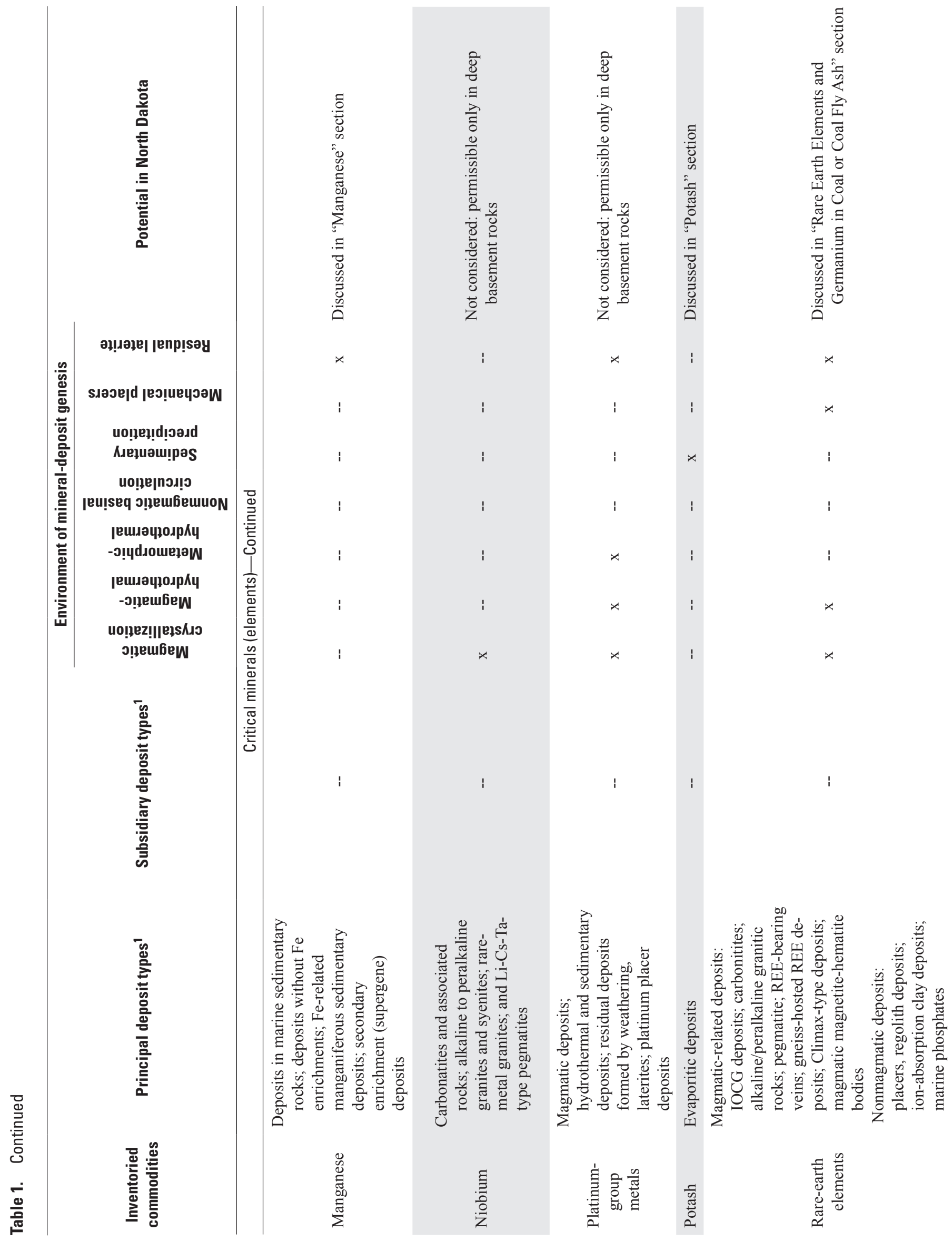




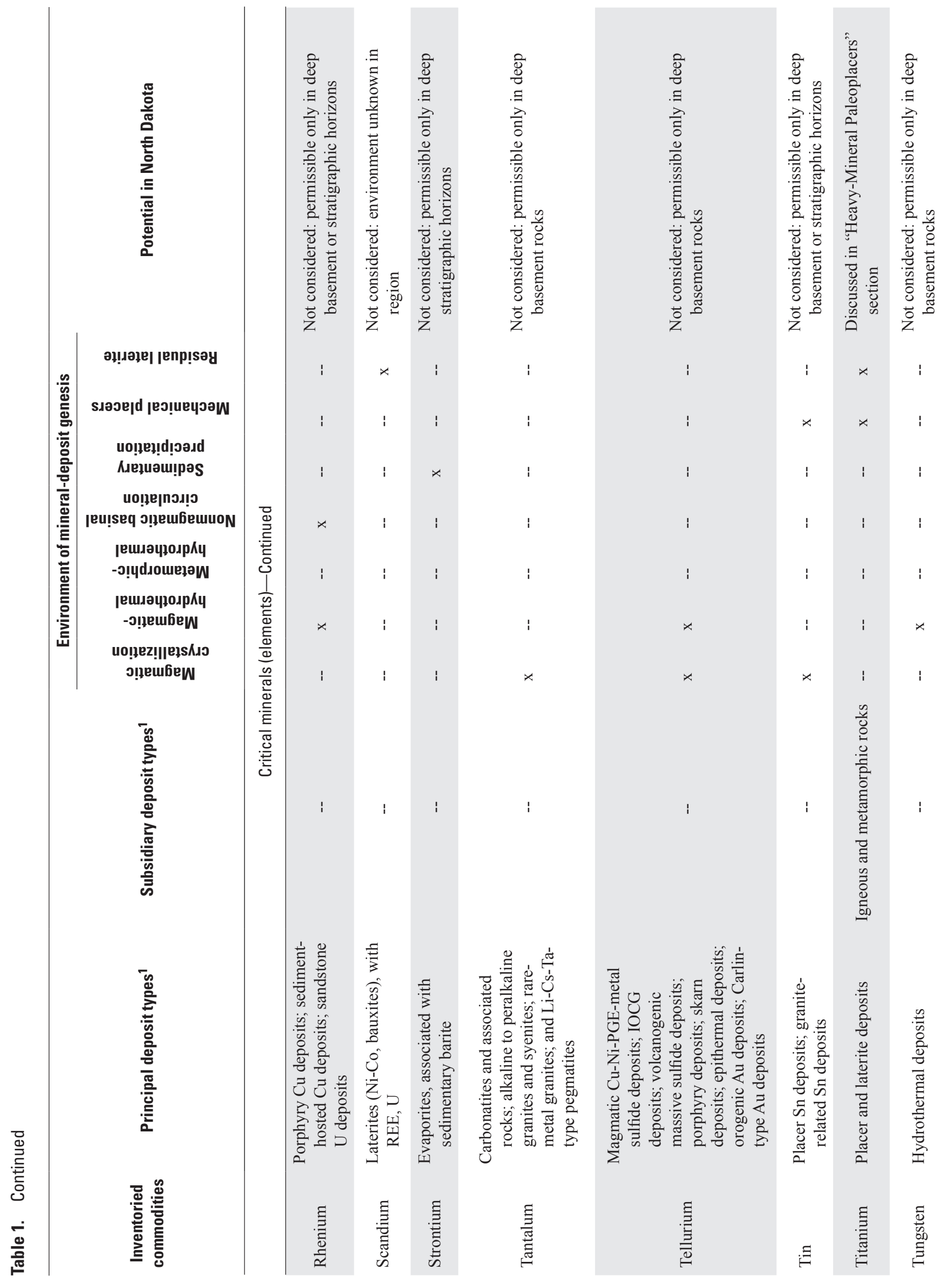




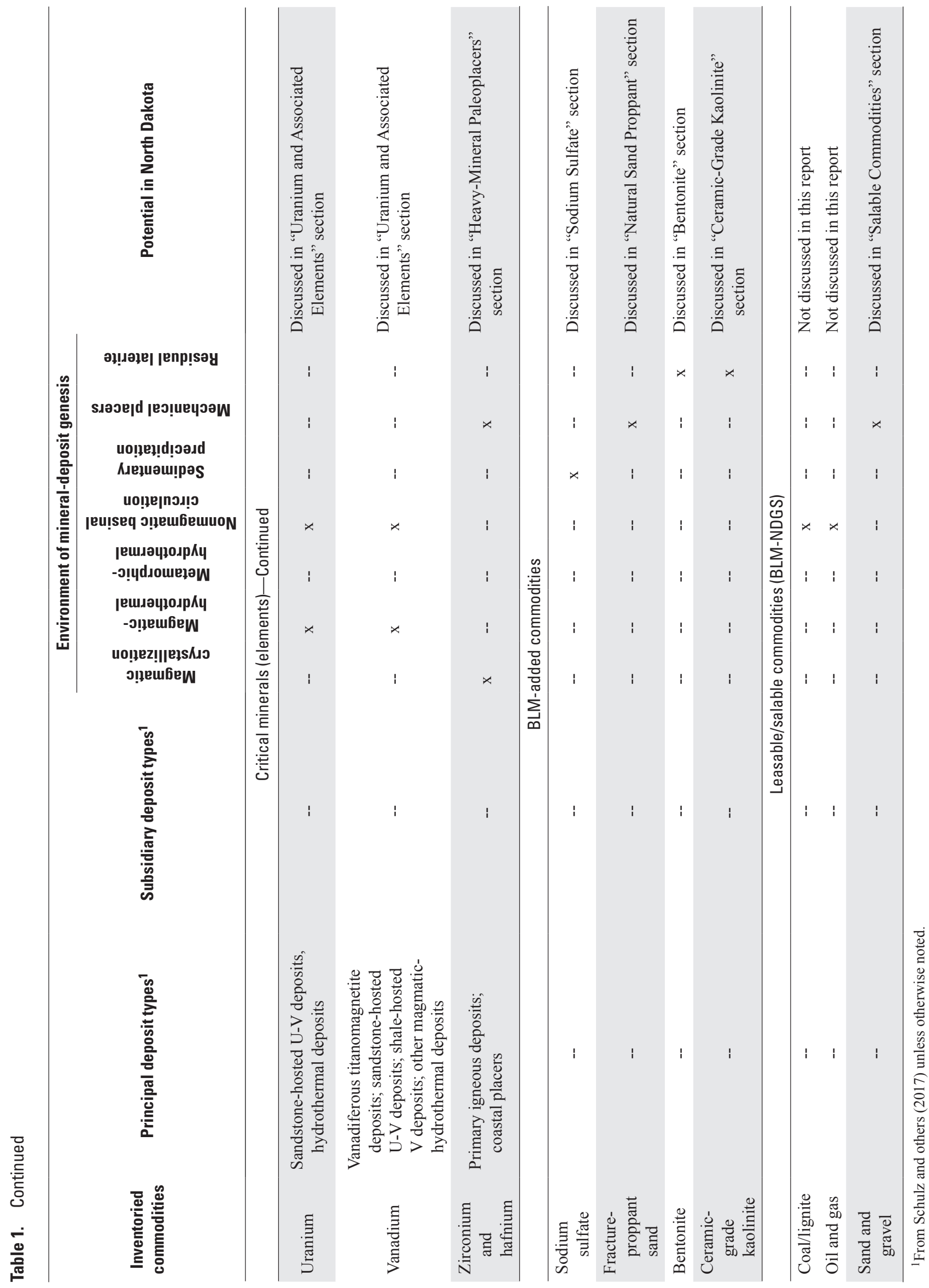


Table 2. Federal and State surface land-management areas in North Dakota

[Distribution of surface land-management areas shown in figure 2 ; --, no data]

\begin{tabular}{|c|c|c|}
\hline Surface land-management jurisdiction & Acreage & Percent of State ${ }^{1}$ \\
\hline \multicolumn{3}{|c|}{ Federal lands } \\
\hline \multicolumn{3}{|l|}{ Department of Agriculture: } \\
\hline Forest Service-National Grasslands & $1,105,788$ & -- \\
\hline \multicolumn{3}{|l|}{ Department of Defense: } \\
\hline \multicolumn{3}{|l|}{ Department of the Interior: } \\
\hline Bureau of Land Management-surface and mineral & 57,975 & -- \\
\hline Bureau of Reclamation & 31,362 & -- \\
\hline National Park Service & 72,150 & -- \\
\hline \multicolumn{3}{|c|}{ State lands } \\
\hline \multicolumn{3}{|l|}{ North Dakota Industrial Commission: } \\
\hline State Forest & 14,108 & -- \\
\hline State Parks & 18,103 & -- \\
\hline Trustland-surface & 707,061 & -- \\
\hline Trustland-mineral & $2,623,841$ & -- \\
\hline Wildlife management areas & 220,021 & -- \\
\hline Total & $3,363,113$ & $7 \%$ \\
\hline
\end{tabular}

${ }^{1}$ Based on total acreage of North Dakota $(45,287,040$ acres $)$

Table 3. Mining claims reported by Bureau of Land Management LR2000 database for North Dakota.

[Data downloaded March 3, 2020 from https://reports.blm.gov/report/lr2000/24//Pub-MC-Geo-Report/). Claimant names omitted for privacy reasons. Locations shown in figure 12. Mer Twn Rng Sec, meridian township range section; Quad, quadrangle; Loc Date, location date; Assmt Yr, assessment year]

\begin{tabular}{|c|c|c|c|c|c|c|c|c|c|}
\hline $\begin{array}{l}\text { Serial } \\
\text { Number }\end{array}$ & $\begin{array}{l}\text { Lead Serial } \\
\text { Number }\end{array}$ & $\begin{array}{l}\text { Mer Twn Rng } \\
\text { Sec }\end{array}$ & Quad & Claim Name & $\begin{array}{c}\text { Claimant } \\
\text { Name }\end{array}$ & ase Type & Status & Loc Date & $\begin{array}{c}\text { Last Assmt } \\
\text { Yr }\end{array}$ \\
\hline MMC203309 & MMC203309 & $\begin{array}{l}051390 \mathrm{~N} \\
1020 \mathrm{~W} 010\end{array}$ & SW & $\begin{array}{l}\text { LITTLE } \\
\text { MISSOURI II }\end{array}$ & Omitted & $R$ & CLOSED & 97 & 1997 \\
\hline MMC203310 & MMC203310 & $\begin{array}{l}051390 \mathrm{~N} \\
1020 \mathrm{~W} 010\end{array}$ & SW & $\begin{array}{l}\text { LITTLE } \\
\text { MISSOURI I }\end{array}$ & Omitted & PLACER & CLOSED & 05/06/1997 & 1997 \\
\hline
\end{tabular}




\section{Appendix 1.}

Tables 1.1-1.4 of appendix 1 may be downloaded in Microsoft Excel and comma-separated values formats from https://doi.org/10.3133/ofr20211057. 
Moffett Field Publishing Service Center, California Manuscript approved for publication May 07, 2021 Edited by Timothy Herold Layout and design by Kimber Petersen 
